\title{
Arbeidsmarktmonitor Metalektro 2012
}

Citation for published version (APA):

Gerards, R., de Grip, A., Künn-Nelen, A. C., \& van Thor, J. A. F. (2013). Arbeidsmarktmonitor Metalektro 2012. ROA. ROA Reports No. 008 https://doi.org/10.26481/umarep.2013008

Document status and date:

Published: 01/01/2013

DOI:

10.26481/umarep.2013008

Document Version:

Publisher's PDF, also known as Version of record

\section{Please check the document version of this publication:}

- A submitted manuscript is the version of the article upon submission and before peer-review. There can be important differences between the submitted version and the official published version of record.

People interested in the research are advised to contact the author for the final version of the publication, or visit the DOI to the publisher's website.

- The final author version and the galley proof are versions of the publication after peer review.

- The final published version features the final layout of the paper including the volume, issue and page numbers.

Link to publication

\footnotetext{
General rights rights.

- You may freely distribute the URL identifying the publication in the public portal. please follow below link for the End User Agreement:

www.umlib.nl/taverne-license

Take down policy

If you believe that this document breaches copyright please contact us at:

repository@maastrichtuniversity.nl

providing details and we will investigate your claim.
}

Copyright and moral rights for the publications made accessible in the public portal are retained by the authors and/or other copyright owners and it is a condition of accessing publications that users recognise and abide by the legal requirements associated with these

- Users may download and print one copy of any publication from the public portal for the purpose of private study or research.

- You may not further distribute the material or use it for any profit-making activity or commercial gain

If the publication is distributed under the terms of Article $25 \mathrm{fa}$ of the Dutch Copyright Act, indicated by the "Taverne" license above, 


\title{
Arbeidsmarktmonitor Metalektro 2012
}

\author{
Ruud Gerards \\ Andries de Grip \\ Annemarie Künn-Nelen \\ Jesper van Thor
}

ROA-R-2013/8 


\section{Colofon}

(C) Researchcentrum voor Onderwijs en Arbeidsmarkt (ROA). Niets uit deze uitgave mag op enige manier worden verveelvoudigd zonder voorafgaande schriftelijke toestemming van de directeur van het ROA.

\section{Researchcentrum voor Onderwijs en Arbeidsmarkt}

School of Business and Economics

Maastricht University

\section{Vormgeving}

ROA secretariaat, Maastricht

\section{Verkoop}

Researchcentrum voor Onderwijs en Arbeidsmarkt email: secretary-roa-sbe@maastrichtuniversity.nl website: www.roa.nl

ISBN: 978-90-532I-516-6 


\section{Inhoud}

Management Summary vii

1 Dynamiek in de Metalektro 1

1.1 Ontwikkelingen in de Metalektro 2012: een jaar met twee gezichten 2

1.2 Ontwikkeling van werkgelegenheid in de Metalektro 1996-2011 6

1.3 Aandachtspunten: Vergrijzing in de Metalektro 6

1.4 Aandachtspunten: upgrading opleidingsniveau $\quad 7$

1.5 Aandachtspunten: innovaties 9

2 Arbeidsmarktontwikkelingen in $2012 \quad 11$

2.1 Daling van het percentage bedrijven met instroom in tweede helft 201212

2.2 Daling van het percentage bedrijven met uitstroom van technische medewerkers in tweede helft 2012

2.3 Bescheiden netto toename in werkgelegenheid in 2012

2.4 Afbouw van de flexibele schil in $2012 \quad 20$

3 Vacatures en werving van personeel 23

3.1 Daling in percentage bedrijven met vacatures 24

3.2 Een nadere blik op vacatures: duur, functiecategorie, ontstaansreden en anticiperen

3.3 Uitzendbureaus en commerciële werving en selectiebureaus zijn meest populaire wervingskanalen

3.42012 was een jaar van uitersten: bedrijven hebben zeer veel of juist zeer weinig wervingsproblemen

4 Competenties en opleidingsinspanningen 41

4.1 Trainingsinspanningen $\quad 42$

4.2 Niveau interne mobiliteit ongewijzigd in 2012

4.3 HR-instrumenten: Toename gebruik van diverse gespreksvormen ('soft'), minder gebruik van meer 'concrete' instrumenten 52

5 Technologische innovaties en organisatorische veranderingen 55

5.1 Technologische innovaties voornamelijk gericht op verbeteringen bestaande producten en processen en nieuwe producten 56

$\begin{array}{ll}5.2 \text { Organisatorische innovaties } & 58\end{array}$ 
6 Pensionering: verwachtingen en uitdagingen

6.1 Onderschatten metalektrobedrijven de aanstaande pensioneringen? $\quad 70$

6.2 Vervangingsproblemen: verwacht en onverwacht 74

6.3 Meerderheid van metalektrobedrijven besteedt actief aandacht aan $\begin{array}{ll}\text { duurzame inzetbaarheid } & 76\end{array}$

6.4 Grote regionale verschillen in aanpak vervangingsproblemen 79

7 De Metalektro in de toekomst

7.1 Tot midden 2013 lijkt de werkgelegenheid in de Metalektro licht te dalen

7.2 Op de middellange termijn worden tekorten verwacht voor specifieke kwalificatiegebieden

7.4 Technische functies zullen meer allround worden en meer verantwoordelijkheden omvatten

7.3 Bevorderen van inzetbaarheid en verminderen van verzuim zijn grote speerpunten $\mathrm{t} / \mathrm{m} 2017$

8 Agenda voor de Toekomst 91

8.1 Inleiding 92

8.2 Ontwikkelingen die de achtergrond vormen 92

8.3 Consolidatie op kernactiviteiten en kern van vaste medewerkers 93

8.4 Op een duurzame manier het aanbod van breed inzetbare technische medewerkers vergroten

8.5 Relevante beleidsterreinen 95 


\section{Voorwoord}

Met genoegen bieden de auteurs van het Researchcentrum voor Onderwijs en Arbeidsmarkt (ROA) en opdrachtgever Stichting $\mathrm{A}+\mathrm{O}$ Metalektro $u$ de Arbeidsmarktmonitor Metalektro $20 \mathrm{O} 2$ aan. De monitor bevat analyses van de actuele en toekomstige ontwikkelingen op personeels- en arbeidsmarktgebied in de Nederlandse Metalektro. De uitkomsten van deze analyses kunnen als input dienen bij het ontwikkelen van personeels- en arbeidsmarktbeleid door metalektrobedrijven, de sociale partners en andere partijen.

De rapportage die voor u ligt vormt het sluitstuk van een onderzoek waarbij gedurende een heel jaar op verschillende momenten gegevens zijn verzameld. De hoofdmoot van de bevindingen in de Arbeidsmarktmonitor Metalektro is gebaseerd op de uitgebreide internetvragenlijst die in 2012 aan het begin van ieder kwartaal door het werkgeverspanel is ingevuld. In 2012 is voor het eerst gewerkt met vier kortere vragenlijsten in plaats van twee keer een langere. Hiermee is de invultijd van de vragenlijst aanzienlijk verkort. In elke meting zijn vragen beantwoord met betrekking tot de in- en uitstroom en vacatures. Een aantal centrale thema's is verdeeld over de vier vragenlijsten: werving en selectie, inzetbaarheid en doorstroom van personeel, sociale en technologische innovatie en scholing en competenties van het technisch personeel. Daarnaast is de eerdere Quickscan in de reguliere vragenlijst geïntegreerd. Deze scan vormt nu de aftrap van iedere vragenlijst. In deze Quickscans geven bedrijven aan hoe de werkgelegenheid en de vacatures zich in de voorgaande en de komende drie maanden ontwikkelen. Om dieper te kunnen ingaan op de achtergronden van de bevindingen uit de vragenlijsten zijn ook een aantal metalektrobedrijven geïnterviewd. Daarnaast is gebruik gemaakt van gegevens afkomstig van het CBS, PME en de arbeidsmarktprognoses van het ROA. ${ }^{\mathrm{I}}$

Wij willen op deze plaats alle bedrijven die de vragenlijsten hebben ingevuld bedanken voor hun bijdrage aan de monitor en hopen dat het rapport en de bedrijfsscan die zij ontvangen hen waardevolle benchmarkinformatie oplevert. Een speciaal woord van dank is daarbij gericht aan de bedrijven die bereid waren om deel te nemen aan de verdiepende gesprekken. De regiecommissie, bestaande uit Quirien van Ojen en Henry de Groot (Stichting A+O Metalektro), Willie Berentsen (FME-CWM) en Peter Niehoff (FNV Bondgenoten), wordt hartelijk bedankt voor hun constructieve

I. ROA (20II), De Arbeidsmarkt naar Opleiding en Beroep tot 20I6, Rapport in het kader van het Project Onderwijs en Arbeidsmarkt, ROA-R-20II/8, Maastricht: ROA. 
feedback en de wijze waarop ze het onderzoek hebben begeleid. Het veldwerk en de dataverzameling voor deze monitor zijn verricht door Sander Dijksman (ROA) en Olga Skriabikova (ROA). Tot slot bedanken wij Ben Kriechel die in 2012 afscheid nam als ROA projectleider van de monitor. 


\section{Management Summary}

De Nederlandse economie kromp in ieder kwartaal van 20I2. Ook de Metalektro is hierdoor geraakt. De sector kende in elk kwartaal een dalende omzet, die met name in het derde en vierde kwartaal fors was. Het percentage bedrijven dat met een terugvallende afzet te kampen heeft stijgt al vanaf begin $201 \mathrm{I}$ en is met name in de tweede helft van 2012 stevig verder gestegen. Desondanks heeft een niet te verwaarlozen percentage bedrijven te kampen gehad met productiebelemmeringen als gevolg van personeelstekorten. Een lichtpunt vormde de ontwikkeling van de totale werkgelegenheid in de Metalektro, die ondanks de moeilijke economisch situatie over het hele jaar gezien een kleine groei vertoonde.

\section{Arbeidsmarktontwikkelingen in 2012}

De werkgelegenheid in de Metalektro is in 2012 licht toegenomen. Dit wordt met name veroorzaakt doordat in de eerste helft van 2012 de instroom van nieuwe medewerkers $(5,2 \%)$ de uitstroom $(3,3 \%)$ ruimschoots oversteeg. In de tweede helft van het jaar was er nog maar sprake van een zeer kleine netto instroom, die voornamelijk in de regio Noord/Oost werd gerealiseerd. In de loop van het jaar steeg het aantal bedrijven waar gesneden werd in het aantal uitvoerende en ondersteunende technische functies. Bedrijven probeerden de krimp vooral te realiseren door middel van een vacaturestop en het niet verlengen van tijdelijke contracten. Deze laatste ontwikkeling is ook terug te zien in de afbouw van de flexibele schil. Deze afbouw had zowel betrekking op een afname van de tijdelijke contracten als het aantal ingeleende personen (zie Hoofdstuk 2).

Ondanks de toename van het aantal bedrijven dat haar personeelsbestand moest inkrimpen, kende de sector als geheel zoals eerder aangegeven in 2012 een lichte netto werkgelegenheidsgroei. De groei heeft vooral betrekking op uitvoerende en leidinggevende technici en engineering en R\&D personeel. Voor deze functies was de netto instroom zowel in de eerste als tweede helft van het jaar positief. Daarentegen kromp in de tweede helft van het jaar de werkgelegenheid in de niet-technische functies.

\section{Werving van personeel}

In alle functiecategorieën zien we in 2012 een daling van het percentage bedrijven met vacatures. 2012 was echter een jaar waarin bedrijven of zeer weinig of juist zeer 
veel moeite hadden met hun personeelswerving. De middengroep die 'gemiddeld' problemen had met hun werving was in 2012 historisch klein (zie Hoofdstuk 3). Het percentage bedrijven met zeer moeilijk vervulbare vacatures bereikte een piek in de zomer van 20I2, maar daalde weer in de tweede helft van het jaar. Het percentage bedrijven met vacatures die 6-I2 maanden open stonden steeg juist in de tweede helft van het jaar. Dit zou in de eerste helft van 2013 tot een nieuwe piek in de langdurig openstaande vacatures kunnen leiden.

Bedrijven wijten hun wervingsproblemen voornamelijk aan een tekortschietend aanbod van sollicitanten en het ontbreken van de juiste competenties en onvoldoende werkervaring bij sollicitanten. De meeste metalektrobedrijven proberen de gevolgen van onvervulde vacatures op te vangen door hun zittend personeel flexibeler in te zetten en/of overuren te laten draaien. Dit leidt ertoe dat een toegenomen werkdruk het meest ondervonden gevolg is van onvervulde vacatures, hoewel het percentage bedrijven dat hiermee te maken heeft in 2012 lager was dan in $201 \mathrm{I}$.

Voor het aantrekken van nieuwe medewerkers vertrouwen metalektrobedrijven al jaren hoofdzakelijk op twee wervingskanalen. Voor de werving van uitvoerende en ondersteunende technici wordt voornamelijk met uitzendbureaus gewerkt. Voor de werving van leidinggevend technisch personeel en technisch opgeleide verkopers werken metalektrobedrijven vooral samen met commerciële werving- en selectiebureaus. Het is opmerkelijk dat het internet als wervingskanaal voor de meeste typen functies in populariteit is afgenomen.

\section{Technologische innovaties en organisatorische veranderingen}

Een belangrijke indicator voor de vitaliteit van de Metalektro is het percentage bedrijven dat in de toekomst productinnovaties verwacht te ontwikkelen. Dit percentage is tussen 2006 en 2012 gedaald van ruim $70 \%$ tot amper $40 \%$ van de bedrijven. In 2012 heeft wel $85 \%$ van alle metalektrobedrijven één of meerdere technologische innovaties doorgevoerd. Hoewel dit een behoorlijk percentage is, is dit minder dan de bedrijven in $201 \mathrm{I}$ verwachtten.

Hetzelfde geldt voor de organisatorische vernieuwingen. Ook hier blijft het percentage bedrijven dat in 2012 vernieuwingen heeft doorgevoerd achter bij de verwachtingen. Desondanks heeft meer dan 30\% van de bedrijven er in 2012 voor gezorgd dat hun eigen technisch personeel meer variabel inzetbaar is. Ook voor de komende jaren lijkt dit een populaire organisatorische vernieuwing. Bedrijven hebben met deze verandering vooral als doel dat hun productie flexibeler wordt.

Het percentage bedrijven dat werkzaamheden uitbesteedde is in 2012 afgenomen. Bedrijven verwachten voor de komende jaren een verdere afname van de uitbesteding van taken aan zowel bedrijven binnen als buiten Nederland. Hierdoor zullen waar- 
schijnlijk bepaalde werkzaamheden weer terug worden geleid naar de eigen kern van medewerkers (zie Hoofdstuk 5).

\section{Vervangingsproblematiek en leeftijdsfasebewust personeelsbeleid}

De vergrijzing in de sector blijft de komende jaren een belangrijk aandachtspunt, aangezien het percentage ouderen binnen de sector al tegen de 30\% aan zit (zie Hoofdstuk 6). Desondanks is er al een aantal jaar een dalende trend in het percentage werknemers dat volgens de metalektrobedrijven de komende vijf jaar met pensioen gaat. Dit illustreert het naar achteren schuiven van de leeftijd waarop medewerkers met pensioen gaan. De verwachte problemen met het vervangen van het personeel dat met pensioen gaat zijn de afgelopen jaren echter niet afgenomen. Sinds 2010 schommelt het percentage bedrijven dat veel vervangingsproblemen verwacht rond de $30 \%$.

Bedrijven zijn in 2012 bewust bezig geweest om de vergrijzings- en vervangingsproblemen te beperken. Meer dan 7 van de Io bedrijven heeft minimaal één HR instrument ingezet om hun personeel duurzaam inzetbaar te houden. Instrumenten die betrekking hebben op het menselijk kapitaal van de huidige werknemers zijn daarbij duidelijk het meest populair. Ook het aantrekken van nieuw personeel wordt door veel bedrijven gezien als een manier om de verwachte vervangingsproblemen in toom te houden.

\section{Voortschrijdende upgrading, competenties en brede inzetbaarheid}

De ontwikkeling van het opleidingsniveau binnen de sector kende de afgelopen jaren een onafgebroken opwaartse trend, met een stijgend percentage $\mathrm{HBO}$ opgeleiden en een dalend percentage $\mathrm{MBO}$ opgeleiden (zie Hoofdstuk I). Bovendien verwachten de bedrijven dat technische functies in de toekomst meer allround zullen worden en dat meer verantwoordelijkheden zullen verschuiven naar technische functies op een lager niveau in de organisatie. Dit gaat gepaard met een toename van het belang van gedragsmatige competenties van medewerkers (zie Hoofdstuk 7). Om de eigen betrokkenheid van werknemers bij hun ontwikkeling te vergroten, kaarten werkgevers dit vooral aan tijdens functioneringsgesprekken en proberen ze dit daarnaast door coachend leiderschap te stimuleren.

In vergelijking met $201 \mathrm{I}$ is de behoefte aan breed inzetbaar uitvoerend technisch personeel toegenomen. Dit heeft zowel te maken met conjuncturele schommelingen in de vraag, met vervanging tijdens afwezigheid, met de manier waarop bedrijven omgaan met onvervulde vacatures als met het verminderen van de uitbesteding van werkzaamheden. In de Agenda voor de Toekomst gaan we nader op deze verbanden in (zie Hoofdstuk 8). Ongeveer 65\% van de bedrijven is tevreden met de mate waarin hun personeel breed inzetbaar is, maar dit betekent ook dat $35 \%$ van de bedrijven aangeeft dat hun personeel onvoldoende breed inzetbaar is. 


\section{Opleidingsbeleid en interne mobiliteit}

In procenten van de totale loonsom, zijn metalektrobedrijven de laatste jaren minder uit gaan geven aan opleiding en training. In 2012 bedroegen de scholingsuitgaven gemiddeld I,3\% van de loonsom (zie Hoofdstuk 4). Trainingsuitgaven komen voor het grootste deel ten gunste van het personeel met een vaste aanstelling. Werkgevers lijken in 2012 bovendien met name bezuinigd te hebben op de trainingsdeelname van personeel met een tijdelijk dienstverband. Technici met een vaste aanstelling of die ingeleend werden ontvingen in 2012 juist iets vaker training dan in 20II. Trainingen zijn doorgaans vooral vaktechnisch gericht en worden in eerste instantie gevolgd met het oog op de uitoefening van de huidige functie. Het initiatief tot deelname aan de trainingen wordt veelal genomen door de direct leidinggevende, of de beslissing om een training te gaan volgen vindt in onderling overleg plaats. Het komt echter nauwelijks vanuit de werknemer zelf.

De grootste belemmeringen die het opleiden van technici in de weg kunnen staan zijn tijd- en geldgebrek, maar er zijn ook veel werkgevers die op dit punt helemaal geen belemmeringen ervaren. Het niveau van de interne mobiliteit is in 2012 ongewijzigd gebleven. Verder wordt er de laatste jaren een toename waargenomen in het gebruik van diverse meer 'softe' instrumenten (gespreksvormen zoals bijvoorbeeld functioneringsgesprekken) die het loopbaanmanagement naar een hoger niveau moeten tillen, terwijl juist minder gebruik wordt gemaakt van de meer concrete HR-instrumenten (bijvoorbeeld EVC trajecten).

\section{Speerpunten toekomstig personeelsbeleid}

Verwachtingen van bedrijven wijzen erop dat de werkgelegenheidsdaling uit de tweede helft van 2012 zich in de eerste helft van 2013 zal doorzetten. Voor specifieke functies zal er desondanks op de middellange tot lange termijn een aanzienlijk tekort ontstaan. Het is dan ook niet verbazend dat bedrijven hun personeelsbeleid in de toekomst vooral richten op het vergroten van de inzetbaarheid van hun personeel, alsmede op het terugdringen van het verzuim. Om dit te realiseren wil men vooral met de medewerkers praten en afspraken maken in de vorm van functioneringsgesprekken, werkoverleg, beoordelingsgesprekken en persoonlijke ontwikkelplannen. Daarnaast zet ruim een derde van de bedrijven functieroulatie in als concreet middel om hun personeelsbeleid vorm te geven (zie Hoofdstuk 7). Door toepassing van functieroulatie worden medewerkers in de praktijk ook meteen breed ingezet, wat beantwoordt aan de toegenomen vraag naar breed inzetbaar personeel. 


\section{Agenda voor de Toekomst}

Het arbeidsmarktbeleid en innovatiegedrag van metalektrobedrijven richt zich in deze economisch woelige tijden voornamelijk op het consolideren van hun kernactiviteiten bij een kern van eigen medewerkers. Van die medewerkers wordt steeds meer een brede en flexibele inzetbaarheid verwacht. Daardoor is er momenteel in veel metalektrobedrijven een tekort aan breed inzetbare technische medewerkers. Dit brengt wel het gevaar met zich mee dat men teveel van medewerkers gaat vragen. Het feit dat de privé-werk balans en de werkdruk laag scoren als HR speerpunten geeft aan dat veel metalektrobedrijven hier nog weinig aandacht voor hebben. De grote uitdaging voor de komende jaren is het op duurzame wijze vergroten van het aanbod van breed en flexibel inzetbare medewerkers.

In dit licht is het zorgelijk dat de out-of-pocket bestedingen aan scholing al jaren dalen. Scholing is namelijk bij uitstek geschikt om medewerkers breder inzetbaar te maken. We zien echter wel dat steeds meer metalektrobedrijven op andere manieren, met gesloten beurs, toch proberen hun medewerkers te scholen en breder inzetbaar te maken, bijvoorbeeld door het toepassen van functieroulatie. Ook dit is een belangrijke route die de metalektrobedrijven de komende jaren verder moeten uitbouwen.

In Hoofdstuk 8 wordt deze Agenda voor de Toekomst verder uitgewerkt. 



\section{Dynamiek in de Metalektro}

De Nederlandse economie kromp in ieder kwartaal van 20I2. Ook de Metalektro is hierdoor geraakt. De sector kende ieder kwartaal een dalende omzet, die met name in het derde en vierde kwartaal fors was. Het percentage bedrijven dat met achterblijvende vraag te kampen heeft stijgt sinds januari $20 I I$ en is met name in de tweede helft van 2012 stevig verder gestegen. Desondanks heeft een niet te verwaarlozen percentage bedrijven te kampen gehad met productiebelemmeringen als gevolg van personeelstekorten.

Een lichtpunt vormde de ontwikkeling van de totale werkgelegenheid in de Metalektro, die ondanks de moeilijke economisch situatie een kleine groei vertoonde over het hele jaar gezien. De vergrijzing in de sector blijft een belangrijk aandachtspunt voor de toekomst, aangezien het percentage ouderen binnen de sector al tegen de 30\% zit. Een ander aandachtspunt is het percentage bedrijven dat in de toekomst productinnovaties verwacht te ontwikkelen. Dit percentage is tussen 2006 en 2012 gedaald van ruim 70\% tot amper 40\%. Daarentegen kende de ontwikkeling van het opleidingsniveau binnen de sector de afgelopen jaren een opwaartse trend, met een stijgend percentage HBO opgeleiden en een dalend percentage MBO opgeleiden. 


\subsection{Ontwikkelingen in de Metalektro 2012: een jaar met twee gezichten}

De Nederlandse economie is in ieder kwartaal van 2012 gekrompen. Volgens cijfers van het CBS kromp de economie het sterkst in het derde en vierde kwartaal, met respectievelijk I, $\%$ en I, $2 \%$ ten opzichte van dezelfde kwartalen een jaar eerder ${ }^{2}$. De conjunctuurontwikkeling in de Metalektro toont een vergelijkbaar verloop. Dit is onder meer te zien in Figuur I.I, die de conjunctuurschommelingen in de Metalektro vanaf 2003 in beeld brengt. Het percentage bedrijven zonder productiebelemmeringen daalde licht in de eerste helft van 2012 en iets sterker in de tweede helft van het jaar. Het percentage bedrijven dat als gevolg van onvoldoende vraag naar hun producten belemmeringen kende in de productie, daalde licht in de eerste helft van 2012 maar steeg sterker in de tweede helft van het jaar. Daardoor is er sinds januari 2OII sprake van een stijgende trend in het percentage bedrijven dat onvoldoende vraag als reden geeft voor hun lagere productie. Het percentage bedrijven dat productiebelemmeringen ondervond als gevolg van een personeelstekort schommelde in 2012 rond de $6 \%$. Dat is hoger dan in 2010 en 201 toen dit nog rond de $3 \%$ schommelde.

Figuur 1.1

Conjunctuurontwikkeling Metalektro, 2003-2012

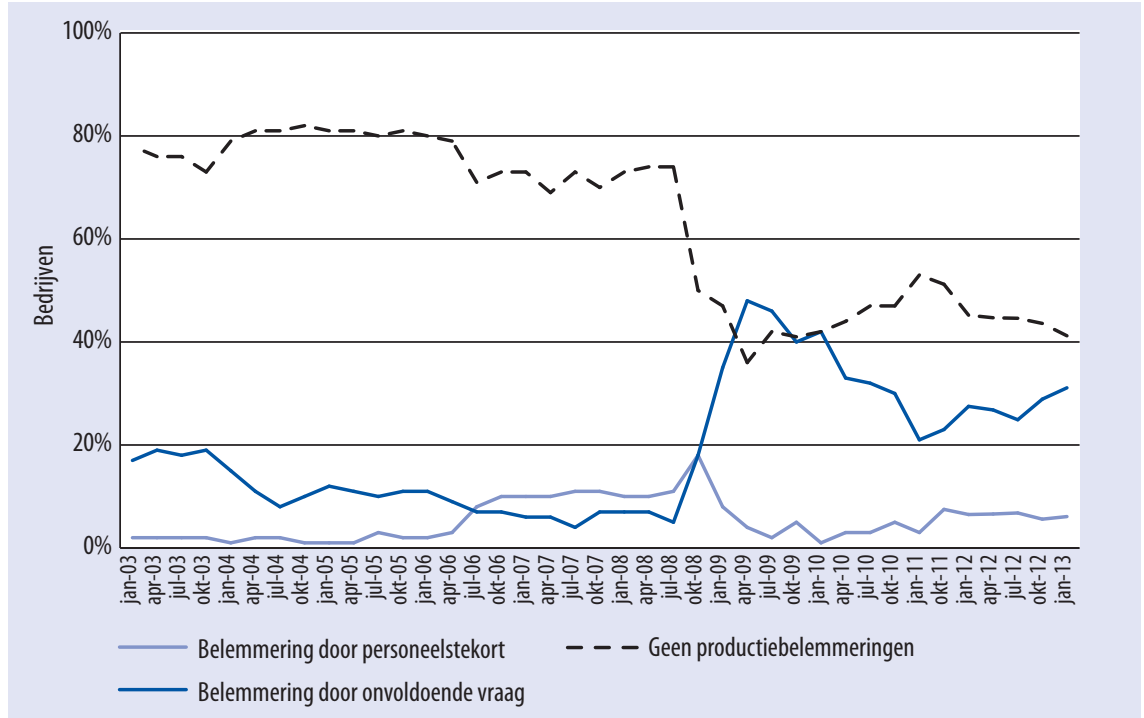

Bronnen: 2003 - jan 2011: CBS Conjunctuurtest Industrie (SBI '93: 27) en voor okt 2011- jan 2013: CBS Conjunctuurenquête Nederland (SBI '08: 24-30, 33)

Figuur I.2 toont de omzetontwikkeling in de Metalektro. De omzet in de Metalektro krimpt gedurende het hele jaar 2012 met de sterkste krimp in kwartalen drie en vier, net als voor de totale Nederlandse economie. Daarmee heeft het herstel uit 20 Io en

2. CBS (20I2). Persbericht PBı2-803 en CBS (20I3). Persbericht PBı3-80o. 
$201 \mathrm{z}$ zich niet voortgezet, hoewel de krimp in $2012 \mathrm{bij}$ lange na niet zo zwaar is als in 2009.

Figuur 1.2

Omzetontwikkeling Metalektro, 2007-2012

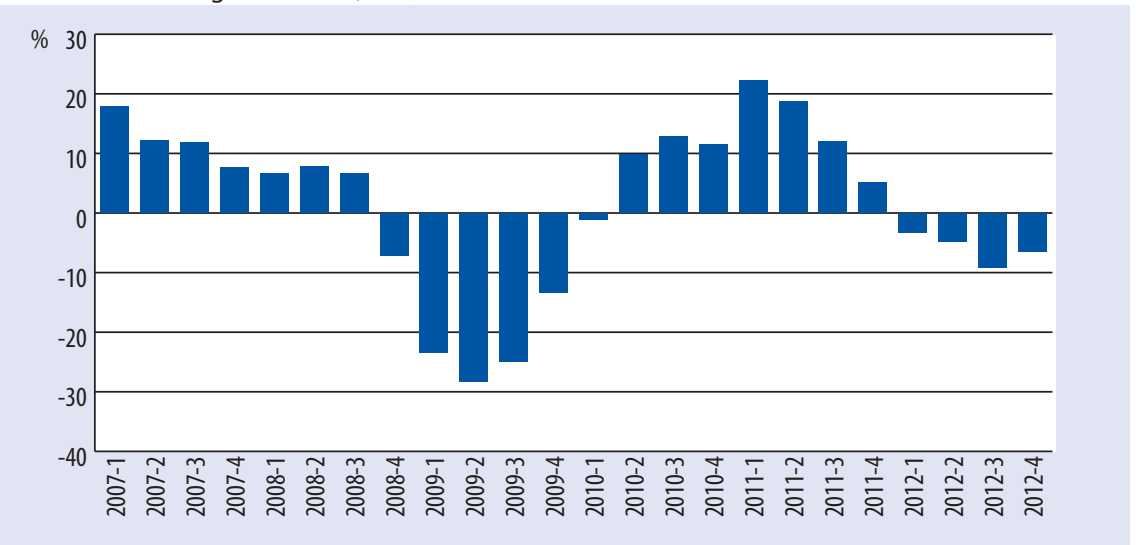

Bron: CBS, Nijverheidsstatistiek, 2007-2012

Ondanks de dalende omzet, laat de werkgelegenheidsontwikkeling in de Metalektro een gemêleerder beeld zien. Figuur I.3 toont een indicator die laat zien of er in het voorgaande kwartaal per saldo meer bedrijven waren die de werkgelegenheid in hun bedrijf zagen toe- of afnemen. Dit wordt in de figuur weergegeven door de blauwe balkjes. Positieve waardes van de indicator duiden er op dat er in dat kwartaal meer metalektrobedrijven waren waar de werkgelegenheid is toegenomen dan is afgenomen. Negatieve waardes van de indicator wijzen er op dat er meer bedrijven waren die moesten snijden in hun personeelsbestand dan bedrijven die in personeelsomvang groeiden.

In mei en juli 2012 was deze indicator nog positief, wat betekent dat er in de eerste helft van 2012 meer bedrijven waren die groei in het personeelsbestand rapporteerden dan bedrijven met krimp in de personeelsomvang. De waardes van oktober 2012 en januari 2013 laten echter zien dat er in de tweede helft van 2012 meer bedrijven waren die te kampen hadden met krimp. De in Figuur I.2 weergegeven relatief lichte omzetdaling in de eerste helft van het jaar, weerspiegelde zich met enige vertraging in de kentering in de indicator van ruim positief in juli 2012 tot ongeveer nul in oktober 20I2. De zware omzetdaling in het derde kwartaal leidde op vergelijkbare wijze tot de negatieve index waarde van personeelsontwikkeling in januari 2013. 


\section{Figuur 1.3}

Indicator personeelsontwikkeling en werkgelegenheidsverwachting, 2009-2012

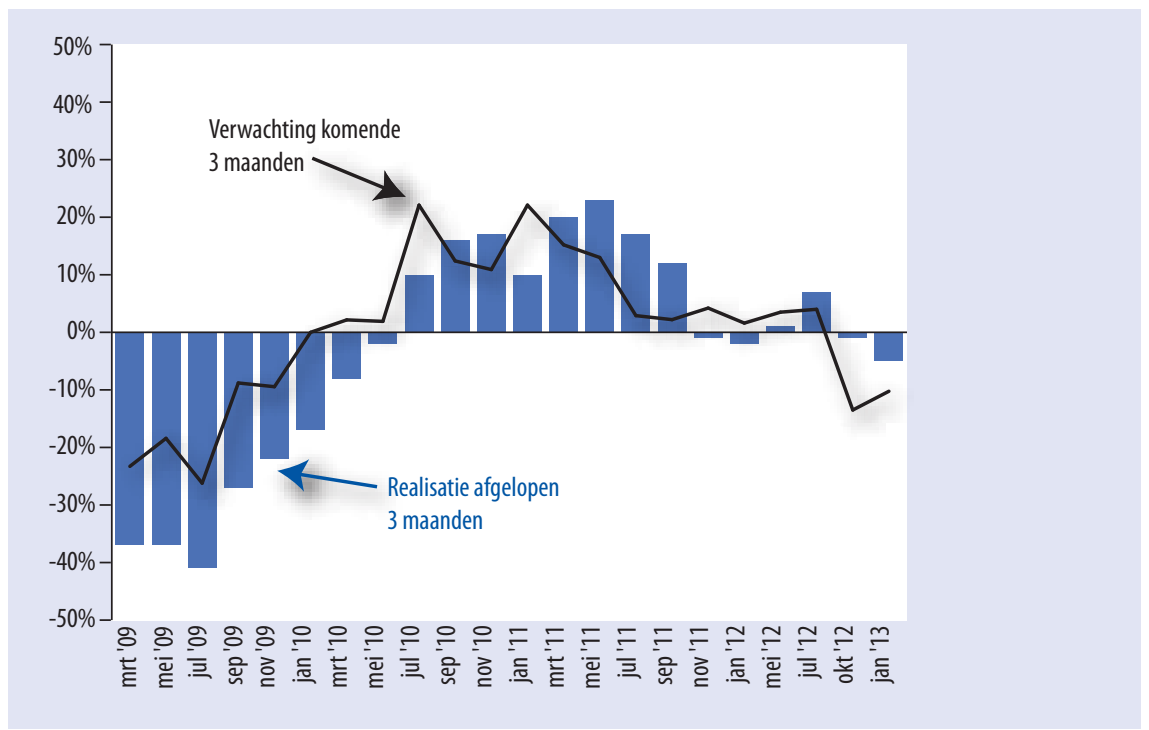

Bron: ROA, Arbeidsmarktmonitor Metalektro, 2009-2012

De zwarte lijn in Figuur I.3 laat zien of bedrijven overwegend positief of negatief zijn over de verwachte werkgelegenheidsontwikkelingen in hun bedrijf in het komende kwartaal. In juli 2012 waren er nog meer bedrijven die verwachtten in kwartaal drie te kunnen groeien qua werkgelegenheid. Echter, in oktober 2012 en januari 20I3, aan het eind van de qua omzetontwikkeling zware derde en vierde kwartalen, ligt de zwarte lijn ruim onder nul en waren er dus meer bedrijven die voor de nabije toekomst werkgelegenheidskrimp verwachtten.

Als we de balans opmaken voor 2012 als geheel, dan kunnen we concluderen dat het jaar twee gezichten had. Ondanks de gestegen productiebelemmeringen en daling in de omzet, was het aantal bedrijven dat groei kende in hun personeelsbestand per saldo groter dan het aantal bedrijven dat krimp kende. De positieve indicator waardes van de personeelsontwikkeling in de eerste helft van het jaar overtreffen net de negatieve waardes van de tweede helft van het jaar. In Hoofdstuk 2 zullen we in meer detail ingaan op de werkgelegenheid in de Metalektro en laten zien dat er sprake was van lichte groei.

De met ongeveer een kwartaal vertraagde reactie van de personeelsontwikkelingen in de Metalektro in 2012 op de omzetontwikkelingen, komt ook tot uiting in de dynamiek in het percentage bedrijven dat aangeeft géén openstaande vacatures te hebben. De onderste grafiek van Figuur I.4 laat zien dat dit percentage tot en met oktober 2012 licht daalde, maar na afloop van het qua omzet zware derde kwartaal het percentage bedrijven zonder vacatures weer scherp toenam. De bovenste grafiek geeft aan hoe 
lang de vacatures gemiddeld open staan bij de bedrijven die wél vacatures hebben. Hieruit blijkt dat het percentage bedrijven waar vacatures gemiddeld langer dan een jaar open stonden in 2012 is gegroeid ten opzichte van de voorgaande jaren. Ook het percentage bedrijven waar vacatures gemiddeld 6 tot 12 maanden open stonden is gegroeid. De percentages bedrijven waar vacatures gemiddeld binnen I maand of binnen 2 maanden werden vervuld is gedaald. Uit deze ontwikkelingen kunnen we afleiden dat bedrijven in de Metalektro in 2012 ondanks de verslechterde landelijke economische situatie en gestegen werkloosheid, gemiddeld lastiger aan de juiste werknemers konden komen dan in recente voorgaande jaren. In Hoofdstuk 3 gaan we hier dieper op in en kijken we ook gericht naar de duur van openstaande vacatures voor het technisch personeel.

\section{Figuur 1.4}

Duur van vacatures, 2010-2012

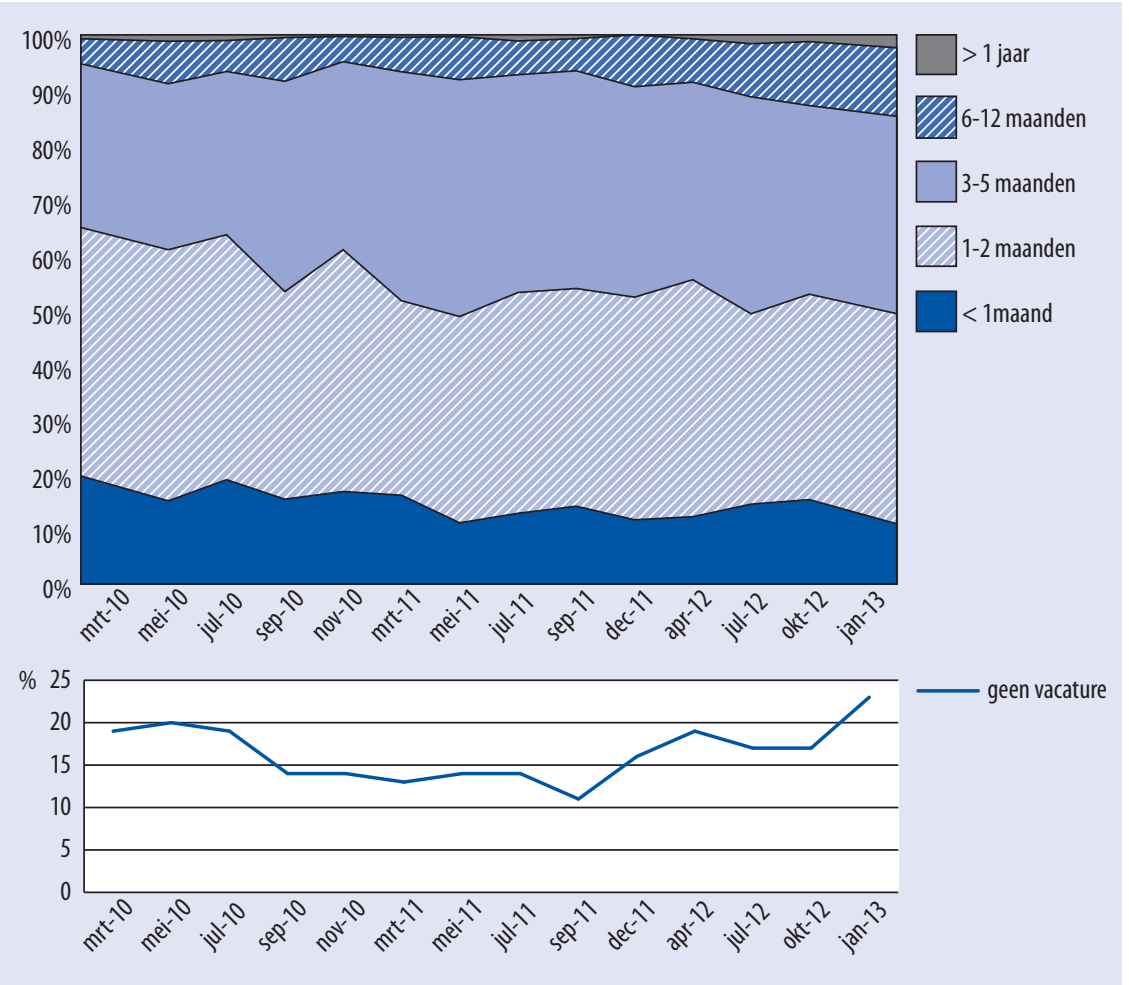

Bron: ROA, Arbeidsmarktmonitor Metalektro, 2010-2012 


\subsection{Ontwikkeling van werkgelegenheid in de Metalektro 1996-2011}

De werkgelegenheid in de Metalektro loopt volgens CBS cijfers al jaren terug. Figuur I.5 toont het indexcijfer voor de werkgelegenheid met als basisjaar 200I. Deze statistiek is op dit moment tot en met 20II beschikbaar. In $201 \mathrm{I}$ was er slechts sprake van een zeer lichte daling in de werkgelegenheid. Cijfers uit het ROA Werkgeverspanel Metalektro die we in de bovenstaande paragraaf hebben opgenomen en cijfers die in Hoofdstuk 2 zullen volgen, duiden er echter op dat er in 2012 een lichte groei in werkgelegenheid heeft plaatsgevonden. Na de zeer lichte daling die uit de CBS cijfers voor $20 I$ blijkt, betekent het resultaat van lichte groei in 2012 uit de arbeidsmarktmonitor wellicht een (tijdelijke) stabilisatie van de tot nu toe structurele daling in werkgelegenheid in de sector.

Figuur 1.5

Werkgelegenheid in de Metalektro, 1996-2011 (index met als basisjaar 2001)

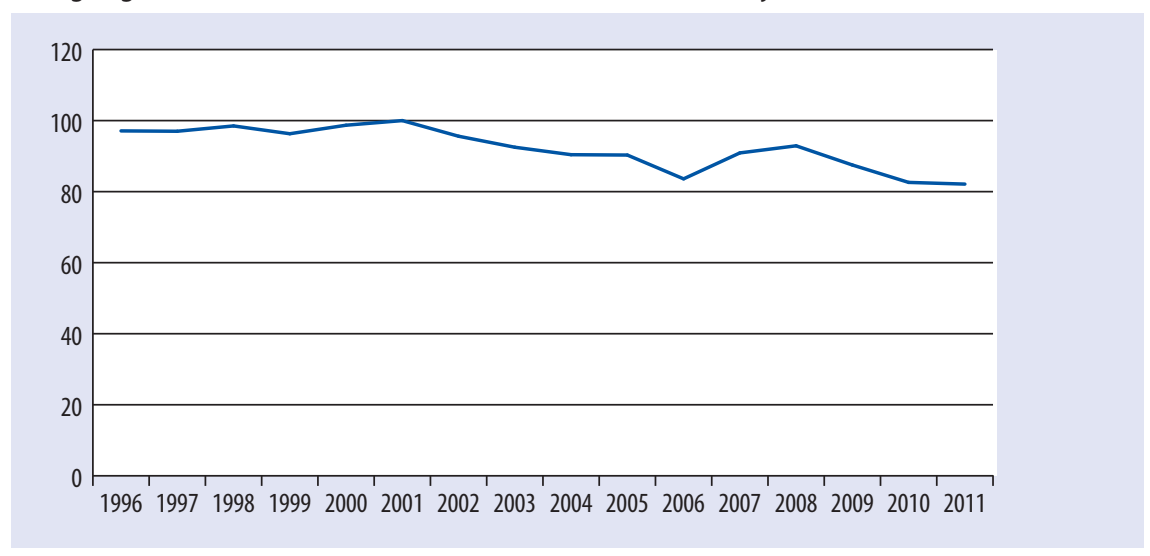

Bron: CBS / Enquête beroepsbevolking, 1996-2011

\subsection{Aandachtspunten: Vergrijzing in de Metalektro}

Een van aandachtspunten waar bedrijven in de Metalektro in toenemende mate alert op zullen moeten blijven is de vergrijzing in de sector. Figuur I.6 toont dat sinds 2010 de groei van het percentage ouderen in de sector sterker is geworden, wat vooral ten koste is gegaan van het percentage werknemers van middelbare leeftijd. Het percentage oudere medewerkers binnen de sector (50-64 jaar) kruipt volgens deze CBS cijfers al jaren omhoog en door de sterkere toename vanaf 2010 komt de $30 \%$ snel in zicht. Een lichtpuntje is dat het aandeel jongeren in de sector na jaren van daling sinds 2OIO is gestabiliseerd. 
Figuur 1.6

Leeftijdsverdeling in de Metalektro, 2006-2011

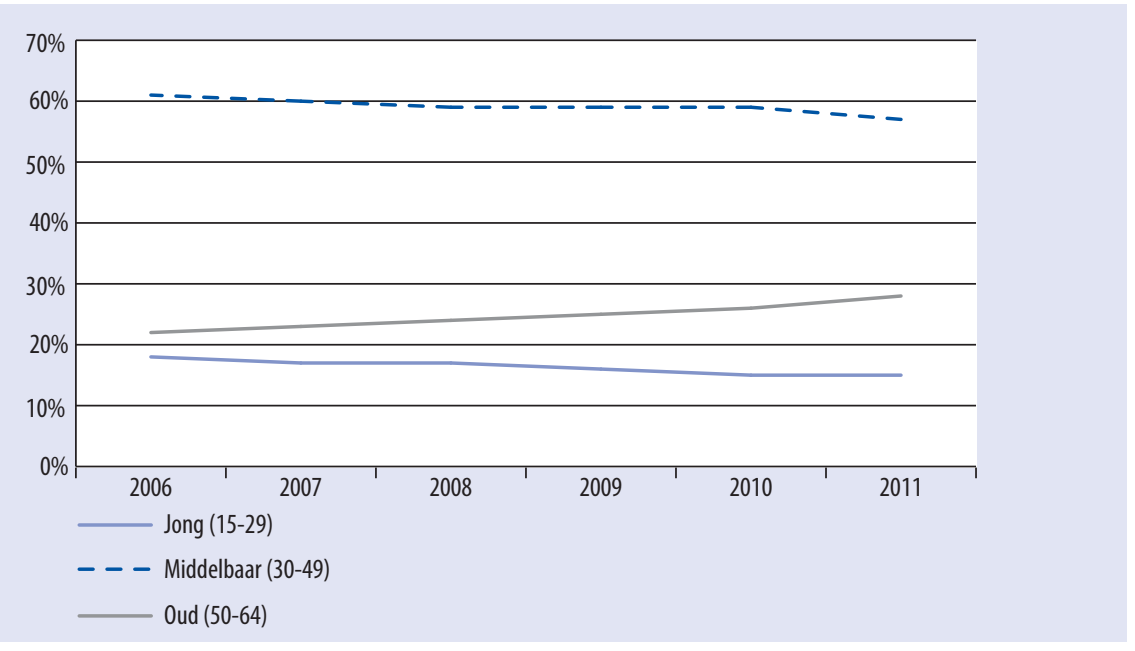

Bron: CBS / Enquête beroepsbevolking, 2006-2011

De toenemende vergrijzing vormt voor de metalektrobedrijven twee uitdagingen die ook in eerdere jaarrapportages van de arbeidsmarktmonitor benoemd zijn, maar aan actualiteit alleen maar hebben gewonnen. Ten eerste zullen de oudere medewerkers op termijn vervangen moeten worden, waarbij de kennis die zich bij deze groep bevindt voor het bedrijf behouden moet blijven. Van het belang van kennisbehoud zijn metalektrobedrijven zich al goed bewust, blijkens figuren 6.6 en 6.7 die in Hoofdstuk 6 zullen laten zien dat ruim $70 \%$ van de bedrijven al inzet op kennisoverdracht. Ten tweede zal als gevolg van de groter wordende groep ouderen en de stijgende pensioenleeftijd gekeken moeten worden of er aanpassingen in het werk of de werkomgeving noodzakelijk zijn om ouderen duurzaam inzetbaar te houden. Ook hierop zal in Hoofdstuk 6 nader worden ingegaan.

\subsection{Aandachtspunten: upgrading opleidingsniveau}

Naast het investeren in de scholing van het personeel, is er in de Metalektro ook sprake van een toenemende upgrading van het opleidingsniveau van het personeel (stijging van het gemiddelde opleidingsniveau). Figuur I.7 geeft op basis van CBS cijfers de dynamiek van het opleidingsniveau in de Metalektro weer tussen 2006 en 20II. Over deze hele periode bezien is er een lichte stijging in het aandeel hoger opgeleiden ( $\mathrm{HBO}$ en WO). Dit komt voornamelijk door een geleidelijke stijging in het aandeel werknemers met een $\mathrm{HBO}$ diploma. Het aandeel MBO'ers is in deze periode licht gedaald terwijl het aandeel lager opgeleiden redelijk stabiel is gebleven. 
Figuur 1.7

Opleidingsniveau in de Metalektro, 2006-2011

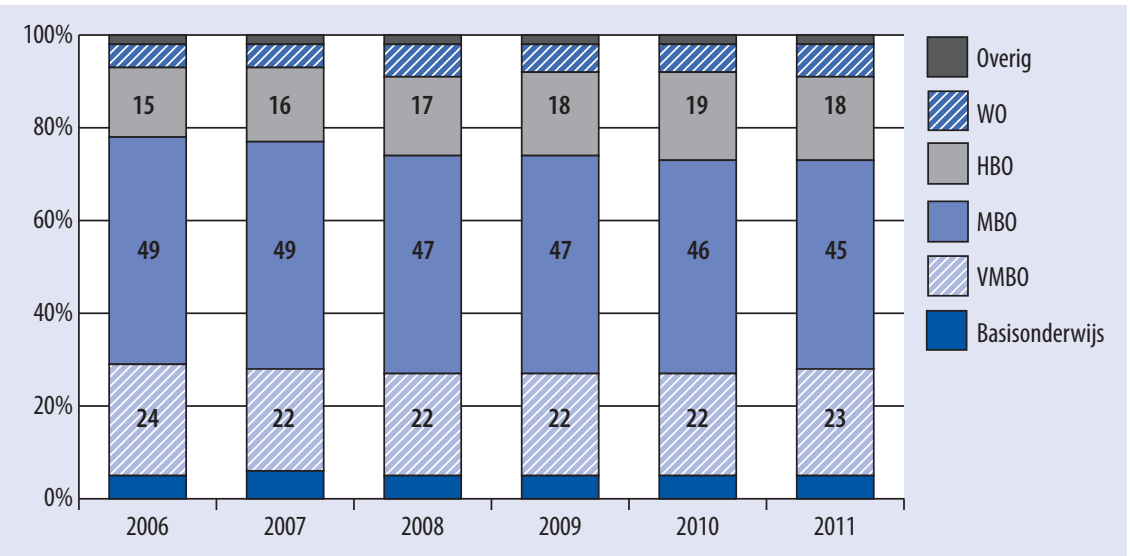

Bron: CBS / Enquête beroepsbevolking, 2006-2011

Hoe de verdeling naar opleidingsniveau er in $201 \mathrm{I}$ uitziet voor de verschillende sectoren binnen de Metalektro is weergegeven in Figuur I.8. Binnen de elektrotechniek vinden we veruit het hoogste percentage hoger opgeleiden en het laagste percentage lager opgeleiden (Basisonderwijs of VMBO). Het omgekeerde geldt voor de sector metaalproducten, waar het aandeel hoogopgeleiden het kleinst is en het aandeel laagopgeleiden het grootst. Met haar hoge aandeel hoogopgeleiden, is de elektrotechniek de enige sector die inmiddels voor gelijke delen bestaat uit hoger opgeleiden en middelbaar opgeleiden (beide maken $40 \%$ van het totaal uit). In alle andere sectoren vormen de MBO'ers de grootste groep. Dat de elektrotechniek hiermee een uitzonderingspositie bekleedt is ook te zien als we terugkijken naar de sector als geheel in Figuur I.7, waarin duidelijk is te zien dat het aandeel MBO'ers, hoewel dalende, nog steeds verreweg het grootst is. Hoewel deze trend van een dalend percentage MBO'ers en stijgend percentage hoger opgeleiden in Figuur I.7 voor de periode 2006-20II als geheel overeind blijft, vormen de ontwikkelingen in $201 \mathrm{I}$ een kleine storing in het beeld. Het aandeel hoger opgeleiden is namelijk iets terug gelopen, terwijl juist het aandeel lager opgeleiden toeneemt. De vraag is of dit een tijdelijk fenomeen is of dat de trend van meer hoog opgeleiden hiermee definitief is geëindigd. 
Figuur 1.8

Opleidingsniveau in Metalektro sectoren, 2011

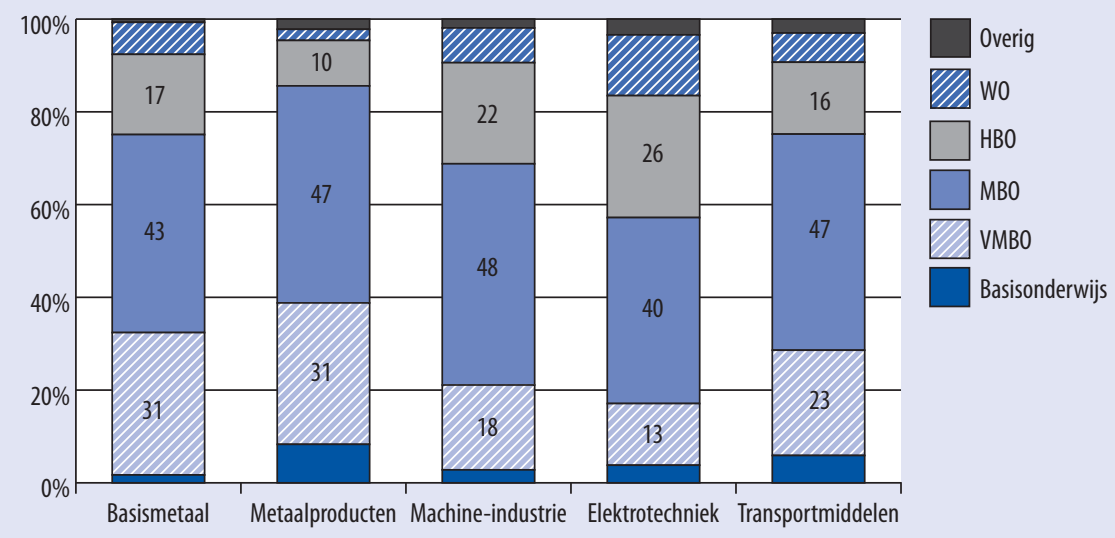

Bron: CBS / Enquête beroepsbevolking, 2011

\subsection{Aandachtspunten: innovaties}

Figuur I.9 toont per jaar, de verwachtingen van de bedrijven op dat moment ten aanzien van hun toekomstige innovaties. Zo verwachtte bijvoorbeeld in 2006 nog $72 \%$ van de bedrijven dat ze in de daarop volgende vijf jaren (2007 tm 20II) productinnovaties zouden ontwikkelen. Sindsdien vertoont deze indicator voor de verwachte productinnovaties een grillig maar dalend verloop. Ondanks een aantal oplevingen in de verwachtingen in 2009 en 20II, zijn de verwachtingen sinds 2006 over het algemeen gedaald. In 2012 verwachtte nog maar $42 \%$ van de bedrijven in de komende vijf jaren (2013 tm 2017) productinnovatie te ontwikkelen. Tot en met het jaar 2009 stond tegenover deze daling in de verwachte productinnovatie, nog een stijging in zowel de verwachte diensteninnovatie als procesinnovatie. Sinds 2009 vertonen echter ook de verwachtingen voor deze laatste twee vormen van innovatie een dalende trend. Het percentage bedrijven dat in 2012 verwachtte in de daarop volgende jaren procesinnovaties te zullen ontwikkelen is wel licht gestegen ten opzichte van 20Ir. Kenmerkend bij deze innovatieverwachtingen is dat de ontwikkelingen in de verwachte product- en procesinnovaties veel grotere uitschieters naar boven en naar beneden kennen dan de verwachtingen ten aanzien van de diensteninnovaties, die eerder lijken te fluctueren rond de $20 \%$. 
HOOFDSTUK 1

\section{Figuur 1.9}

Verwachte innovaties voor de komende vijf jaar (\% bedrijven), 2006-2012.

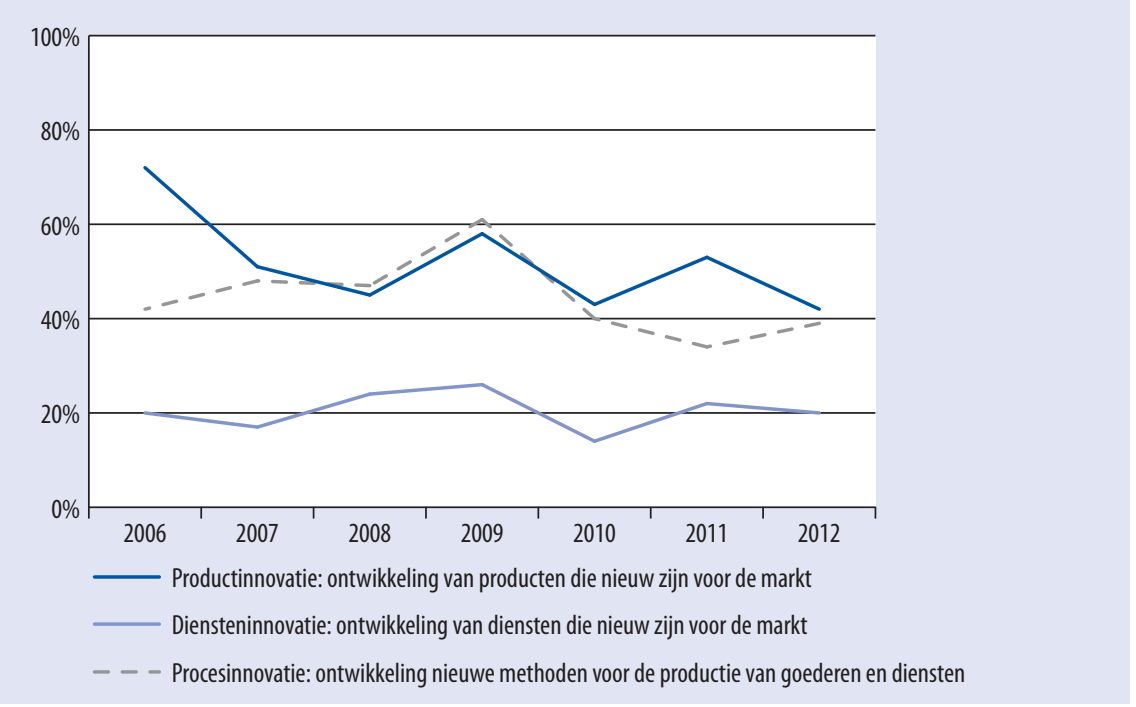

Bron: ROA, Arbeidsmarktmonitor Metalektro, 2006-2012 


\section{Arbeidsmarktontwikkelingen in 2012}

In totaliteit is de werkgelegenheid in de Metalektro in 2012 licht toegenomen. Dit wordt met name veroorzaakt doordat de instroom van nieuwe medewerkers in de eerste helft van 2012 (5,2\%) de uitstroom ruimschoots oversteeg (3,3\%). In de tweede helft van het jaar was er nog maar sprake van een zeer kleine netto instroom, die voornamelijk door de regio Noord/Oost werd gerealiseerd. In de loop van het jaar steeg het aantal bedrijven waar gesneden werd in het aantal uitvoerende en ondersteunende technische functies. Bedrijven probeerden de krimp vooral te realiseren door middel van een vacaturestop of door tijdelijke contracten niet langer te verlengen. Deze laatste ontwikkeling is ook terug te zien in de afbouw van de flexibele schil. Dit had zowel betrekking op een afname van de tijdelijke contracten als het aantal ingeleende personen. 


\subsection{Daling van het percentage bedrijven met instroom in tweede helft 2012}

Het percentage bedrijven met instroom ${ }^{3}$ van nieuwe medewerkers zegt iets over de dynamiek in de Metalektro. In de loop van 2012 nam het percentage bedrijven dat nieuwe medewerkers heeft aangenomen af. Driekwart van de bedrijven $(74 \%)$ gaf aan nieuwe medewerkers te hebben aangetrokken in de eerste helft van 20I2. In de tweede helft van het jaar nam dit af tot twee derde $(66 \%)$ van de bedrijven. Van alle regio's nam de instroom in de regio Zuid het meest af. In deze regio daalde het percentage bedrijven met instroom van nieuwe medewerkers van $83 \%$ (januari-juni) naar $60 \%$ in de tweede helft van het jaar. Daarmee veranderde het Zuiden in de loop van het jaar van de regio waar bedrijven het vaakst nieuwe medewerkers aantrokken, in de regio waar bedrijven juist het minst vaak nieuwe medewerkers aantrokken.

Evenals in voorgaande jaren namen bedrijven in 2012 vooral nieuwe medewerkers aan voor uitvoerende technische functies (Figuur 2.I). In de eerste helft van 2012 was er bij $60 \%$ van de bedrijven sprake van instroom van medewerkers voor deze functiecategorie. Niettemin daalde dit percentage met $9 \%$-punt in de tweede helft van het jaar.

\section{Figuur 2.1}

Percentage bedrijven met instroom naar functiecategorie, 2012

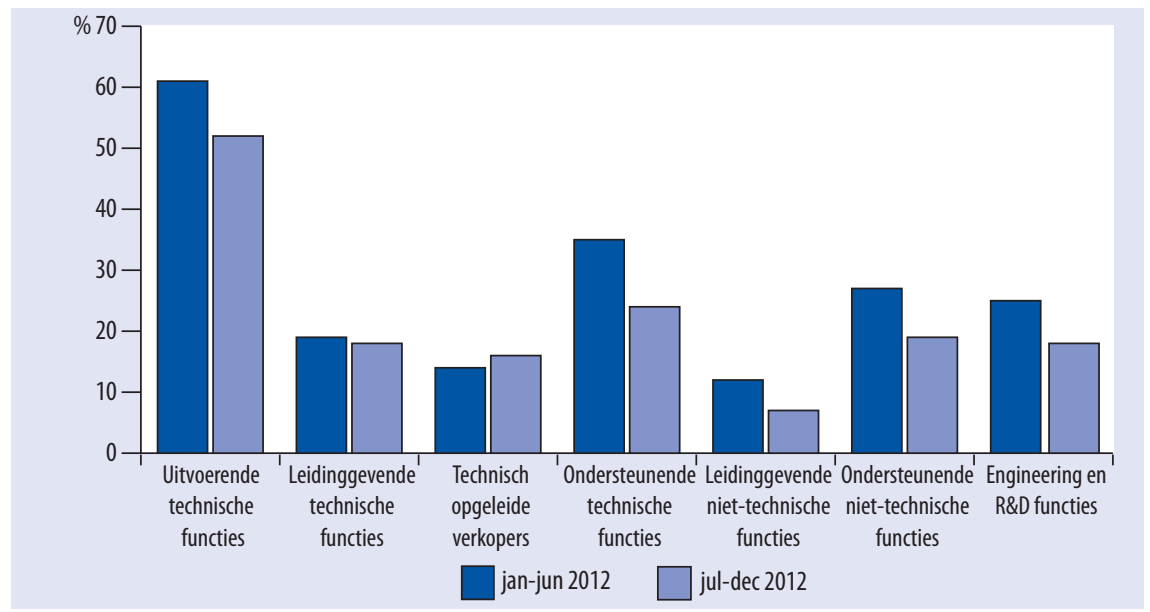

Bron: ROA, Arbeidsmarktmonitor Metalektro, 2012

Deze teneur van een afnemende instroom in de tweede helft van het jaar deed zich in vrijwel alle andere functiecategorieën voor. De enige uitzonderingen hierop vormen de leidinggevende technische functies en technisch opgeleide verkopers, waarvoor het percentage bedrijven met instroom min of meer constant bleef. Van alle functiecate-

3. De hier besproken personeelsinstroom in de Metalektro heeft alleen betrekking op nieuwe werknemers die in dienst komen bij bedrijven in de sector. Dit is dus exclusief personen die door de metalektrobedrijven ingeleend worden zoals uitzendkrachten of gedetacheerden. Deze flexibele schil komt aan bod in paragraaf 2.4 . 
gorieën daalde in de tweede helft van 2012 de instroom van nieuwe medewerkers het hardst voor de ondersteunende technische functies (II\%-punt). Een nadere analyse bracht aan het licht dat bij grote bedrijven in alle functiecategorieën relatief vaker instroom plaatsvond dan bij het MKB.

\subsection{Daling van het percentage bedrijven met uitstroom van technische medewerkers in tweede helft 2012}

Tegenover de hiervoor besproken instroom van nieuwe medewerkers stond uiteraard ook uitstroom ${ }^{4}$ van medewerkers. Aan de werkgevers is in 2012 tweemaal gevraagd of er in de zes maanden daarvoor medewerkers zijn geweest die hun bedrijfsvestiging hebben verlaten. Dit hoeft dus niet te betekenen dat deze medewerkers die vertrokken zijn eveneens vertrokken zijn uit de sector Metalektro als zodanig. In de eerste helft van 2012 was er in $73 \%$ van de bedrijven sprake van uitstroom van medewerkers. In de tweede helft van het jaar daalde dit zeer licht tot $70 \%$.

Bedrijven met personeelsuitstroom in 2012 namen het vaakst afscheid van medewerkers die werkzaam waren in uitvoerende technische functies. Ongeveer de helft van de bedrijven had te maken met uitstroom van personeel uit deze grootste functiecategorie. In de tweede helft van het jaar was de uitstroom van medewerkers uit de uitvoerende technische functies echter lager dan in de eerste helft van het jaar. Ook daalde in de tweede helft van 2012 het percentage bedrijven met uitstroom van ondersteunend technisch personeel en personeel in engineering en R\&D functies. Het percentage bedrijven met uitstroom van ondersteunend niet-technisch personeel en technisch opgeleide verkopers liet daarentegen juist een stijging zien in de tweede helft van het jaar. Het aantal bedrijven met uitstroom van medewerkers met leidinggevende functies, ongeacht technisch of niet-technisch van aard, veranderde nauwelijks. Tot slot moet opgemerkt worden dat, evenals bij de instroom, het percentage grote bedrijven dat met uitstroom te maken had voor alle functiecategorieën hoger was dan voor het midden- en kleinbedrijf.

Wanneer het percentage bedrijven met uitstroom (Figuur 2.2) in 2012 afgezet wordt tegen de bedrijven met instroom (Figuur 2.I), dan valt op dat er een duidelijk verschil bestaat tussen de eerste en de tweede helft van het jaar. In de eerst helft van het jaar oversteeg de instroom de uitstroom nog in alle functiecategorieën. Echter, in de tweede helft van het jaar werd het verschil tussen beide kleiner. In de leidinggevende niet-technische functies en de ondersteunende niet-technische functies waren er zelfs iets meer bedrijven met uitstroom dan met instroom. Dit wijst er op dat uitstroom uit functies die niet-technisch van aard zijn, niet langer automatisch tot vervangende instroom leidt. Het is reëel om te veronderstellen dat bedrijven zich bij economische

4. Deze personeelsuitstroom heeft alleen betrekking op vertrokken werknemers die in dienst waren bij bedrijven in de sector. Dit is dus exclusief personen die door de metalektrobedrijven ingeleend werden, zoals uitzendkrachten of gedetacheerden. Deze flexibele schil komt aan bod in paragraaf 2.4. 
tegenspoed doorgaans allereerst op hun primaire (technische) proces richten. Deze gedachte wordt ondersteund door het gegeven dat in de tweede helft van het jaar het percentage bedrijven met instroom alleen voor de uitvoerende technische functies, ondersteunende technische functies en de engineering en $R \& D$ functies, hoger was dan het percentage bedrijven met personeelsuitstroom.

\section{Figuur 2.2}

Percentage bedrijven met uitstroom naar functiecategorie, 2012

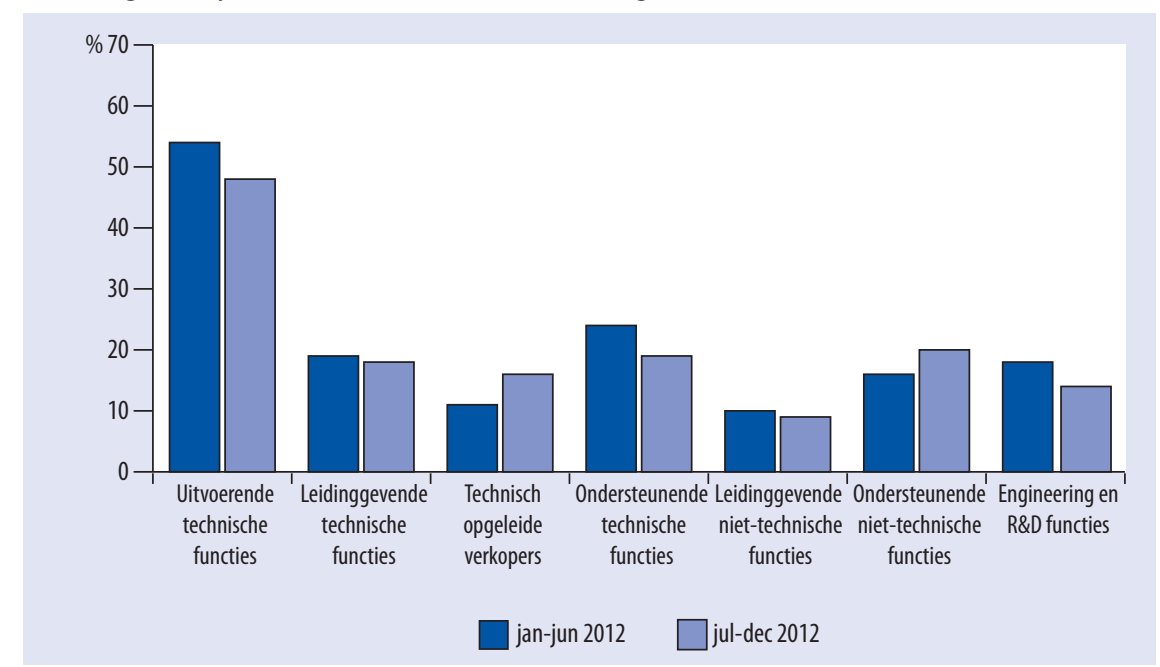

Bron: ROA, Arbeidsmarktmonitor Metalektro, 2012

\section{Nader bekeken: De in- en uitstroom van uitvoerende technische functies}

Het uitvoerend technisch personeel vormt al jaren de grootste functiecategorie. Voor deze grote groep kijken we in Figuur 2.3 naar de ontwikkeling van de instroom en uitstroom in de afgelopen jaren. Tussen 2005 en 2012 fluctueerde het percentage bedrijven met instroom behoorlijk en kwam daarbij regelmatig boven de $70 \%$, maar zelden onder de $40 \%$. Na de intrede van de economische crisis, welke leidde tot een forse daling van de instroom in de eerste helft van 2009 , herstelde de instroom geleidelijk tot in ruim $60 \%$ van de bedrijven in de eerste helft van 201 . Vervolgens daalde het percentage bedrijven met instroom van uitvoerende technici weer licht tot $52 \%$ in de tweede helft van 20I2. Dergelijke percentages waren ruim voor het uitbreken van de economische crisis ook niet ongebruikelijk. Het lijkt er dus op dat de instroom op korte termijn sterk reageert op economische ontwikkelingen, maar vaak weer terugkeert naar gemiddeld ongeveer $55 \%$ van de bedrijven.

Het percentage bedrijven met uitstroom van uitvoerend technisch personeel fluctueert iets minder en kent sinds 2008 een dalende trend. Tot de eerste helft van 2008 was er nog een stijgende trend waarneembaar, maar hierna daalde het percentage bedrijven 
met uitstroom van uitvoerend technisch personeel gestaag. De exacte redenen die hieraan ten grondslag liggen zijn niet bekend, maar wellicht zijn medewerkers terughoudender om in deze onzekere tijden van baan te wisselen en kiezen ze er derhalve voorlopig voor om bij hun huidige werkgever te blijven. Ook speelt hier mogelijk mee dat medewerkers langer door moeten blijven werken waardoor zij pas later met pensioen gaan. Mogelijk heeft ook de deeltijd-WW regeling die tussen 2009 en 20 I van kracht was, ertoe bijgedragen dat de uitstroom in die periode bleef dalen terwijl er toch sprake was van een economische crisis. Wellicht houden bedrijven bewust, al dan niet met behulp van de deeltijd-WW, hun technici aan boord om voorbereid te zijn op de verwachte toekomstige tekorten aan technici. Een klein teken dat duidt op voorzichtig herstel is dat vanaf 20 II voor het eerst na het uitbreken van de economische crisis het instroompercentage weer boven het uitstroompercentage ligt. Er zijn sindsdien meer bedrijven met instroom dan met uitstroom.

\section{Figuur 2.3}

Percentage bedrijven met in- c.q. uitstroom van uitvoerend technisch personeel, 2005-2012

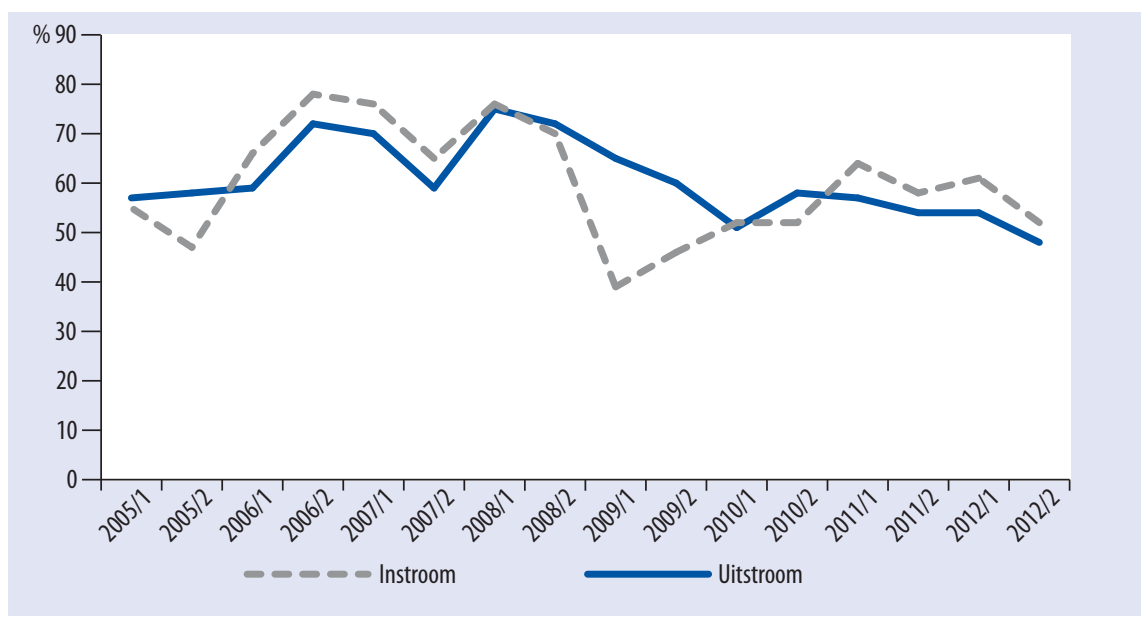

Bron: ROA, Arbeidsmarktmonitor Metalektro, 2005-2012

\subsection{Bescheiden netto toename in werkgelegenheid in 2012}

In de paragrafen 2.I en 2.2 werd de instroom en uitstroom van personeel gedefinieerd als het percentage bedrijven dat in zijn algemeenheid met instroom dan wel uitstroom te maken had. In paragraaf 2.3 wordt een andere invalshoek gekozen. Er is de deelnemende bedrijven gevraagd naar de aantallen ingestroomde en uitgestroomde medewerkers en het totaal aantal werkzame personen. Op basis hiervan biedt paragraaf 2.3 in- en uitstroomcijfers, als percentage van het totaal aantal werkenden. Hiermee wordt met meer precisie duidelijk of er sprake was van netto instroom (groei) of netto uitstroom (krimp) van medewerkers in de Metalektro. Figuur 2.4 laat zien hoe groot 
het instroompercentage en het uitstroompercentage in 2012 waren. Hierbij wordt onderscheid gemaakt tussen de eerste en tweede helft van het jaar.

Figuur 2.4 laat zien dat de werkgelegenheid in de Metalektro zich in 2012 in algemene zin positief ontwikkeld heeft. Zo oversteeg in de eerste helft van 2012 de instroom van nieuwe medewerkers $(5,2 \%)$ nog ruimschoots de uitstroom $(3,3 \%)$. Dit veranderde echter in de tweede helft van het jaar. Om te beginnen is het instroompercentage in de tweede helft van 2012 met I,2\%-punt gedaald tot 4,O\%. Daar staat tegenover dat de ontwikkeling van de uitstroom juist de omgekeerde weg bewandelt en is gestegen van $3,3 \%$ naar $3,8 \%$. Het verschil tussen de instroom en uitstroom bedraagt daarmee in de tweede helft van het jaar nog maar 0,2\%-punt. Hoewel er dan nog altijd sprake is van een kleine netto instroom, is dit een verslechtering ten opzichte van de eerste helft van 2012.

\section{Figuur 2.4}

Werkgelegenheidsontwikkeling: in- en uitstroom van werknemers als percentage van het totaal aantal werknemers, 2012

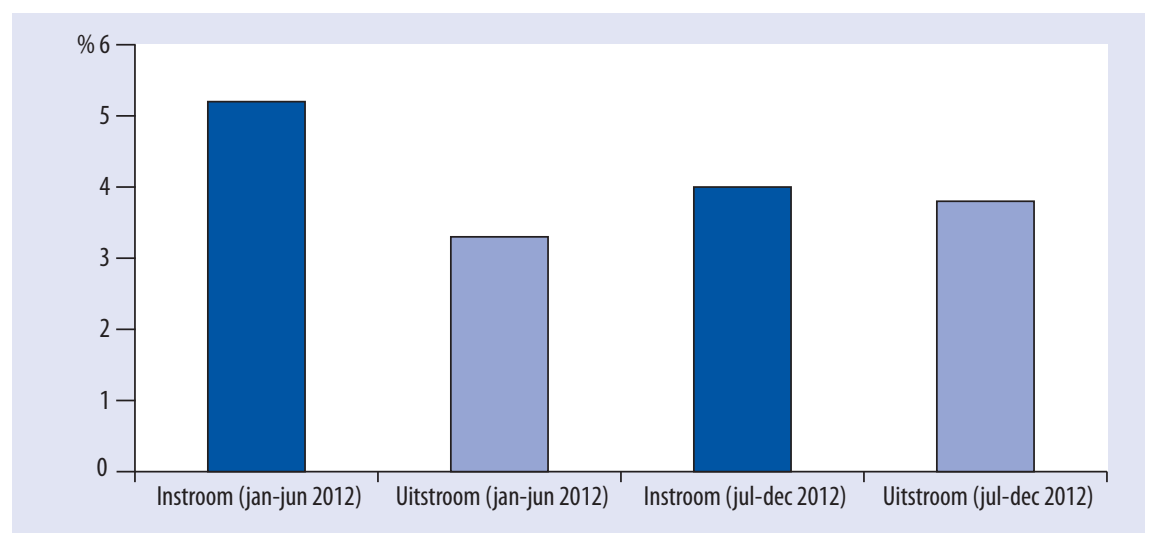

Bron: ROA, Arbeidsmarktmonitor Metalektro, 2012

\section{Regio Noord/Oost redt de totale werkgelegenheid in de Metalektro}

Figuur 2.5 laat zien dat er in 2012 aanzienlijke regionale verschillen bestonden qua in- en uitstroompercentages. In de eerste helft van het jaar was de instroom in elke regio hoger dan de uitstroom. De instroom is in de tweede helft van het jaar echter in alle drie de regio's afgenomen. Tot zover volgen alle regio's het landelijke beeld. Wat afwijkt van het landelijk beeld en van de ontwikkeling in de andere regio's, is dat er in de regio West in de tweede helft van 2012 sprake was van een netto uitstroom: een kleine afname van de werkgelegenheid. Eveneens afwijkend van het landelijke beeld en van de andere regio's zijn de ontwikkelingen in de regio Noord/Oost. In deze regio werd ook in de tweede helft van het jaar nog een duidelijke netto stijging van de 
werkgelegenheid gerealiseerd: het instroompercentage was hier ruim twee keer groter dan het uitstroompercentage.

\section{Figuur 2.5}

Regionale werkgelegenheidsontwikkelingen: in- en uitstroom van werknemers als percentage van het totaal aantal werknemers, 2012

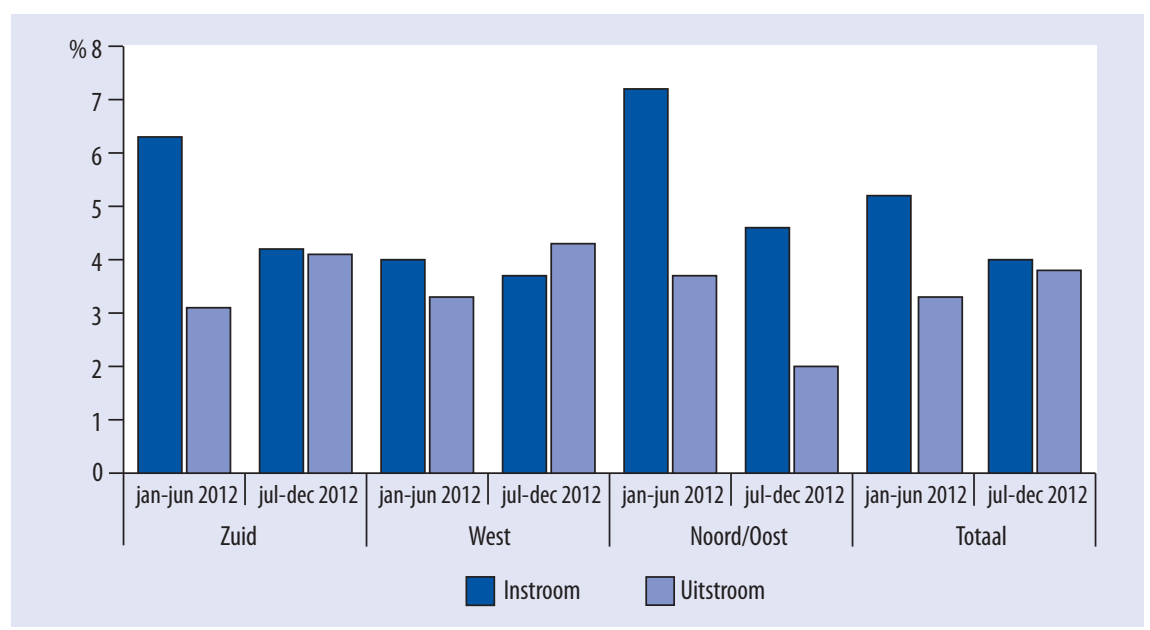

Bron: ROA, Arbeidsmarktmonitor Metalektro, 2012

\section{Werkgelegenheidstoename voor technici + engineering en $R \& D$-functies}

Figuur 2.6 toont voor de eerste en tweede helft van 2012 het gemiddelde percentage ingestroomde en uitgestroomde werknemers ten opzichte van de totale werkgelegenheid bij Metalektrobedrijven. Metalektrobedrijven kenden in de eerste helft van 2012 in de meeste functiecategorieën een netto instroom. Alleen bij de leidinggevende niettechnische functies vond in de eerste helft van het jaar een netto uitstroom plaats. In de tweede helft van 2012 hadden alleen technische functies en engineering en R\&D functies nog netto instroom. Vooral voor de leidinggevende technische functies als ook de engineering en R\&D-functies geldt dat ook in de tweede helft van 2012 de instroom nog altijd duidelijk groter is dan de uitstroom. Voor uitvoerende technici is de instroom maar net groter dan de uitstroom in de tweede helft van het jaar. Opvallend is verder dat er in de tweede helft van het jaar per saldo meer uitstroom van medewerkers was in twee niet-technische functiecategorieën: de leidinggevende en de ondersteunende niet-technische functies. Eerder zagen we dit voor deze beide functiecategorieën ook al bij de vergelijking van het percentage bedrijven met instroom c.q. uitstroom (Figuren 2.I en 2.2). 


\section{Figuur 2.6}

Werkgelegenheidsontwikkelingen naar functiecategorie: in- en uitstroom van werknemers als percentage van het totaal aantal werknemers, 2012

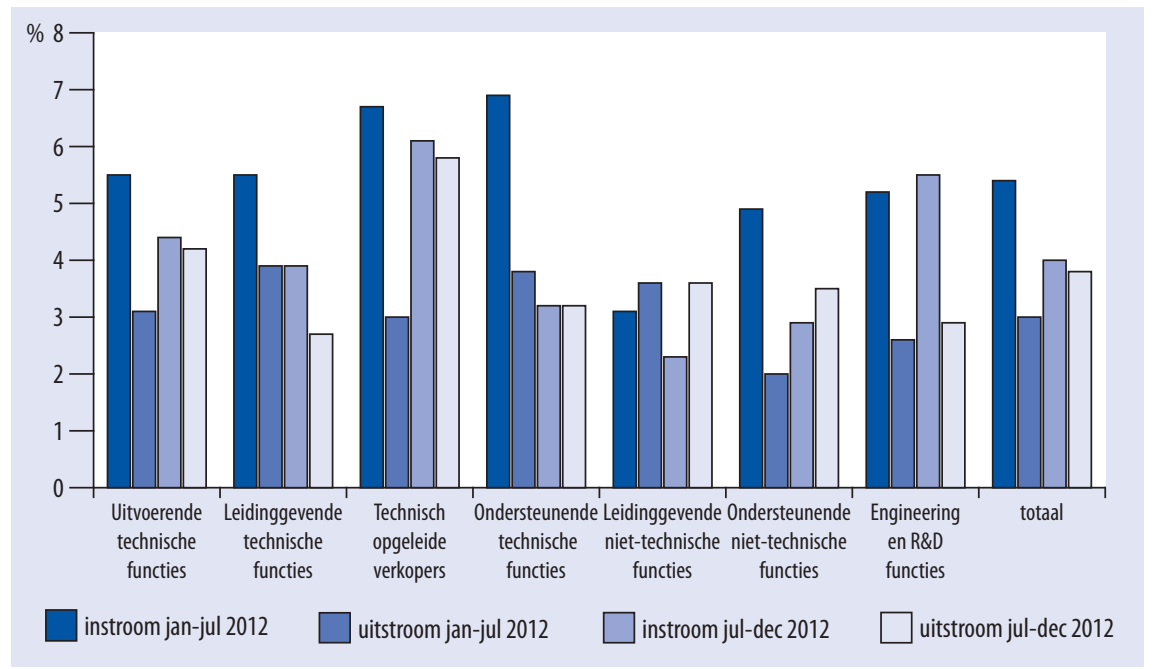

Bron: ROA, Arbeidsmarktmonitor Metalektro, 2012

\section{Toename bedrijven met krimp van uitvoerende en ondersteunende technische functies}

Aan de deelnemende bedrijven is tevens gevraagd in welke functiecategorie(ën) de werkgelegenheid in hun bedrijfsvestiging afneemt. Figuur 2.7 geeft per functiecategorie weer welk deel van de bedrijven meldt dat de werkgelegenheid in hun bedrijfsvestiging in de betreffende functies afneemt. Hierbij wordt gebruik gemaakt van de informatie op de peilmomenten juli 2012 en januari 20I3. Voor diverse functiecategorieën nam het percentage bedrijven dat krimp rapporteerde toe in de tweede helft van het jaar. De functiecategorie waar de meeste bedrijven krimp voor rapporteerden is de categorie van de uitvoerende technische functies. In 2012 nam de werkgelegenheid bij gemiddeld een kwart van de bedrijven af in de uitvoerende technische functies. Daar komt bij dat dit percentage bedrijven met krimpende werkgelegenheid toenam in de tweede helft van het jaar. De toename van het percentage bedrijven met krimp is echter nog sterker te zien bij twee andere functiecategorieën: de technisch opgeleide verkopers en het ondersteunend technisch personeel. Hier tegenover staat dat er relatief weinig bedrijven in 2012 krimp meldden voor technisch opgeleide verkopers en engineering en R\&D-personeel. In de tweede helft van 2012 daalde het percentage bedrijven met krimp voor engineering en $\mathrm{R} \& \mathrm{D}$-functies zelfs tot $6 \%$ (op peilmoment januari 2013). 
Figuur 2.7

Percentage bedrijven met krimpende werkgelegenheid naar functiecategorie, 2012

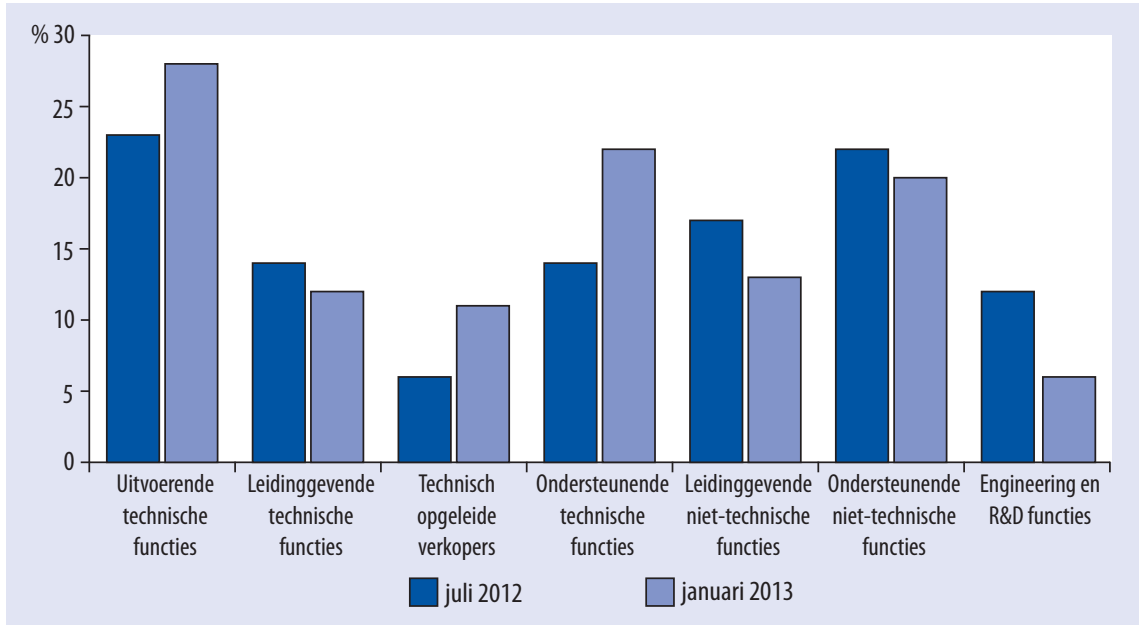

Bron: ROA, Arbeidsmarktmonitor Metalektro, 2012

\section{Hoe vangen bedrijven krimpende werkgelegenheid op?}

Aan de bedrijven die in 2012 te kampen hadden met teruglopende werkgelegenheid voor technici is ook gevraagd hoe ze met deze terugloop omgaan. In Figuur 2.8 worden de gevolgen van de krimpende werkgelegenheid in 2012 opgesomd en vergeleken met die in 20II. De vaakst genoemde gevolgen van de krimpende werkgelegenheid in 2012 komen overeen met die in 20II. In de helft van de bedrijven die in 2012 te kampen had met krimpende werkgelegenheid van het technisch personeel werd dit bewerkstelligd door een vacaturestop. Bovendien werden tijdelijke contracten in vier op de tien bedrijven niet verlengd. Beide maatregelen werden in 2012 iets vaker genoemd dan in het jaar ervoor. Ook werd er gebruik gemaakt van het natuurlijk verloop door werknemers die met pensioen gaan niet meer te vervangen. Een derde van de bedrijven met krimpende werkgelegenheid probeert (mede) op deze wijze de afnemende werkgelegenheid op te vangen, waardoor de gevolgen voor het vaste personeel beperkt zijn. Een ander gevolg van de krimpende werkgelegenheid houdt eveneens verband met pensionering. Bij ruim een kwart van deze bedrijven werden werknemers in 2012 gestimuleerd om eerder met pensioen te gaan. Deze maatregel werd in 2012 een stuk vaker toegepast dan in 20II. Wat ten opzichte van 201 sterk is gedaald is het percentage bedrijven dat aangaf dat werknemers op eigen initiatief zijn vertrokken. Dit percentage is in 2012 meer dan gehalveerd. Werknemers lijken daarmee in 2012 voor zekerheid te kiezen door te blijven werken bij hun huidige werkgever. Ook het percentage bedrijven dat werknemers overplaatst naar andere functies of stimuleert om een andere baan te zoeken is meer dan gehalveerd. 


\section{Figuur 2.8}

Wijze waarop krimpende werkgelegenheid van technisch personeel wordt gerealiseerd, 2011-2012

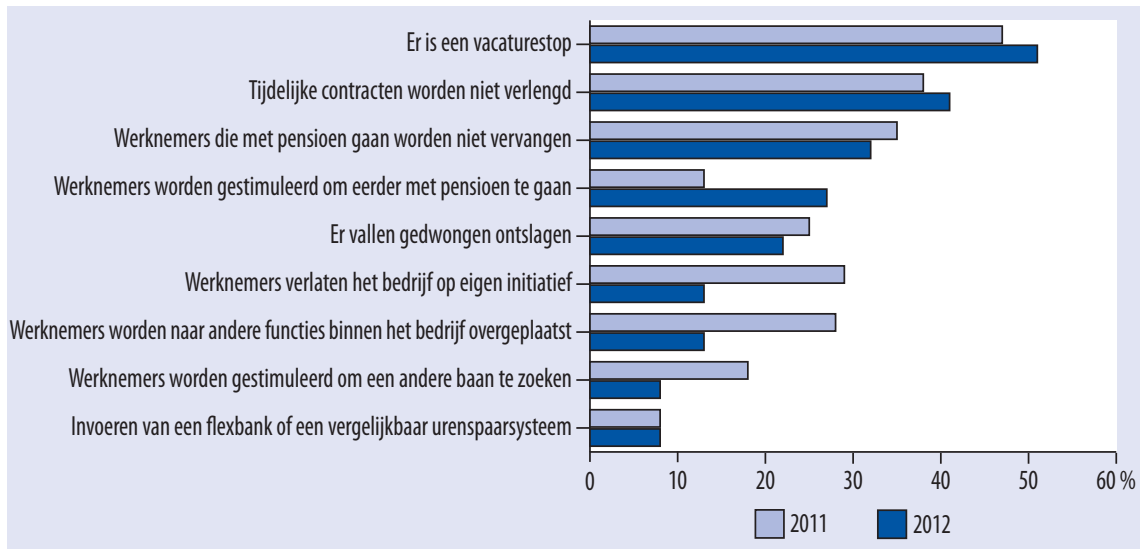

Bron: ROA, Arbeidsmarktmonitor Metalektro, 2011-2012

\subsection{Afbouw van de flexibele schil in $\mathbf{2 0 1 2}$}

In Figuur 2.8 zagen we al dat het niet verlengen van tijdelijke contracten een vaak voorkomende maatregel is om de krimpende werkgelegenheid op te vangen. Veranderingen in de omvang van de flexibele schil lopen in het algemeen vaak vooruit op bredere arbeidsmarktontwikkelingen. Figuur 2.9 toont dat de flexibele schil in de Metalektro tussen januari 2012 en juli 2012 is gegroeid van I $2 \%$ naar $15 \%$ van de totale personeelsomvang in de sector. In januari 2013 was de omvang van de flexibele schil echter gedaald tot II\%. Aan het einde van 2012 was de flexibele schil in de Metalektro dus kleiner dan aan het begin van 2012.

Binnen de totale flexibele schil onderscheiden we enerzijds 'eigen' medewerkers met een tijdelijke aanstelling en anderzijds medewerkers die worden ingeleend van bijvoorbeeld uitzend- of detacheringsbureaus. Het percentage medewerkers dat werkzaam is op uitzend- of detacheerbasis $(6 \%)$ is op peilmoment januari 2013 twee procentpunt lager dan in juli $2012(8 \%)$. In tijden van economische onzekerheid of krimp wordt er doorgaans het eerst gesneden in deze groep ingeleende medewerkers. Ook het percentage tijdelijke contracten daalde in deze periode, van $7 \%$ in juli 2012 tot $5 \%$ in januari 20I3. Doordat bedrijven snijden in de omvang van de flexibele schil, neemt verhoudingsgewijs het aandeel van het personeel met vaste dienstverbanden toe. Dit verklaart waarom in de tweede helft van het jaar $89 \%$ van het personeel van de metalektrobedrijven in vaste loondienst werkte, terwijl dit in de eerste helft van het jaar nog $85 \%$ was. Het werk wordt dus voor een steeds groter deel verricht door het (zittende) vaste personeel. 
Figuur 2.9

Omvang van de flexibele schil in de Metalektro als percentage van totaal aantal medewerkers, 2012

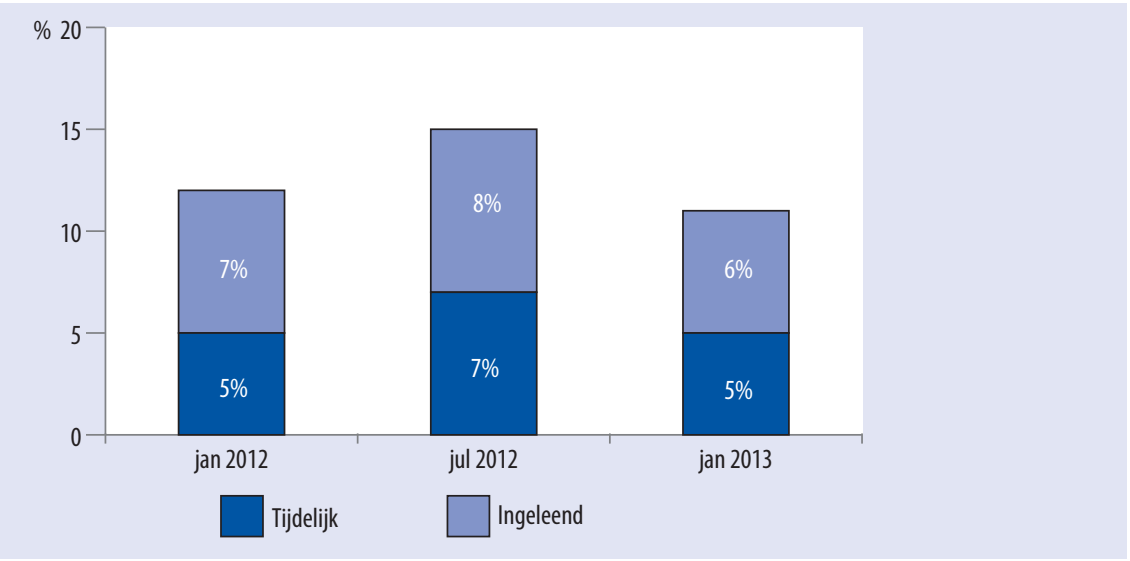

Bron: ROA, Arbeidsmarktmonitor Metalektro, 2012

Uit Figuur 2.Io blijkt dat de samenstelling van de flexibele schil sterk uiteenloopt tussen de verschillende functiecategorieën. De figuur geeft voor 2012 per functiecategorie weer hoe groot de flexibele schil is. Hierbij wordt opnieuw onderscheid gemaakt tussen de omvang van de flexibele schil op drie peilmomenten: januari 20I2, juli 2012 en januari 20I3. In algemene zin is er een tweedeling zichtbaar tussen enerzijds functiecategorieën met een flexibele schil van gemiddeld Io\% of meer en anderzijds functiecategorieën met slechts $5 \%$ of minder flexibele contracten. Tot de functiecategorieën met een klein aandeel flexibele arbeidskrachten behoren de technisch opgeleide verkopers en de leidinggevende technische en niet-technische functies. In de uitvoerende technische functies, ondersteunende technische en niet-technische functies, en engineering en R\&D-functies is het aandeel flexibele contracten hoger. De functiecategorie engineering en $\mathrm{R} \& \mathrm{D}$, die in $20 \mathrm{I} 2$ voor het eerst opgenomen is, blijkt meteen voor een relatief hoog percentage uit flexibele krachten te bestaan.

Uit de figuur blijkt dat bedrijven tussen januari 2012 en januari 2013 de omvang van de flexibele schil in vrijwel elke functiecategorie hebben teruggeschroefd. Alleen de flexibele schil van leidinggevende technici is over het hele jaar gezien licht uitgebreid. Als we de ontwikkeling van de flexibele schil apart bekijken voor de eerste en de tweede helft van 20I2, zien we dat technische functiecategorieën zich onderscheiden van niet-technische functies. We kijken eerst naar de technische functies. In de eerste helft van het jaar, groeide de flexibele schil van leidinggevende en ondersteunende technici. Tevens kromp de flexibele schil van uitvoerende technici maar zeer beperkt. In de tweede helft van het jaar, kromp de flexibele schil van uitvoerende en ondersteunende technici echter scherp en kromp ook de flexibele schil van leidinggevende technici. Als we kijken naar de niet-technische functies, zien we dat zowel voor de leidinggevende en ondersteunende niet-technische functies, alsmede voor technisch opgeleide verkopers (commercieel), de flexibele schil in de eerste helft van het jaar scherper afnam dan in de tweede helft van het jaar. 
Figuur 2.10

Flexibele schil (\% medewerkers) naar functiecategorie, 2012

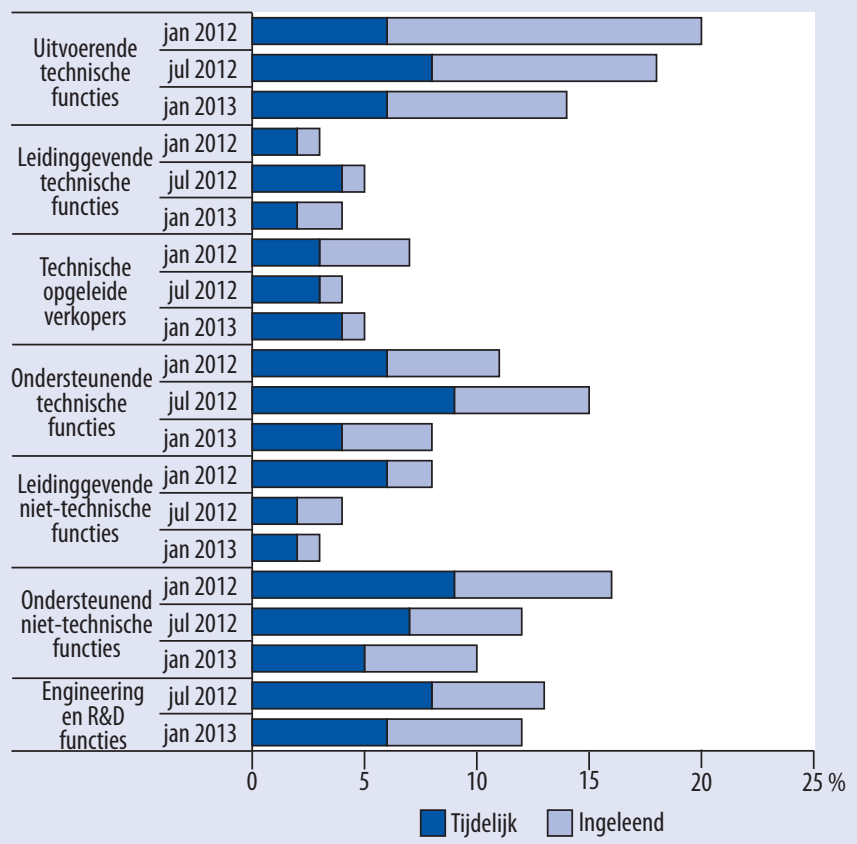

Bron: ROA, Arbeidsmarktmonitor Metalektro, 2012

Noot: Het overige deel van de dienstverbanden in elke functiecategorie bestaat uit medewerkers in vaste dienst. De vaste contracten plus de flexibele schil tellen samen op tot $100 \%$. Zo vormt het aandeel vaste contracten in de uitvoerende technische functies op peilmoment juli 2012 bijvoorbeeld $82 \%$.

Noot: In 2012 werd voor het eerst de functiecategorie 'Engineering en R\&D' onderscheiden. Daardoor is voor deze categorie geen informatie in deze figuur opgenomen voor januari 2012. De januari 2012 informatie bij de andere categorieën berust namelijk op de vierde meting van 2011 waarin de categorie 'Engineering en R\&D' nog niet bestond.

Om hier nadere duiding aan te geven memoreren we kort aan Figuur I.2. Uit Figuur I.2 weten we dat de omzet in de Metalektro zich in $201 \mathrm{I}$ nog positief ontwikkelde, maar dat deze wel ieder kwartaal van dat jaar al wat minder positief werd. In de eerste helft van 2012 kromp de omzet in de Metalektro, maar was deze krimp relatief licht. Bij deze licht krimpende omzet, bouwden de Metalektrobedrijven in eerste instantie de flexibele laag van niet-technische functies af. De flexibele laag van technische functies, die meer aan het primaire proces gerelateerd is dan de niet-technici, werd nog uitgebreid of kromp zeer minimaal. Pas toen in de tweede helft van 2012 de omzet sterker daalde, hebben Metalektrobedrijven ook scherp in de flexibele schil van technische functies gesneden. Metalektrobedrijven maken in tijden van economische tegenspoed dus onderscheid bij het inkrimpen van de flexibele schil: eerst de relatief minder essentiële niet-technische flexibele laag afbouwen en als de tegenspoed aanhoudt ook snijden in de technische flexibele schil. 


\section{Vacatures en werving van personeel}

In alle functiecategorieën zien we in 2012 een daling van het percentage bedrijven met vacatures. 2012 was echter een jaar waarin bedrijven zeer weinig of juist zeer veel moeite met werving hadden. De groep die 'gemiddeld' problemen had met werving was in 2012 historisch klein. Het percentage bedrijven met zeer moeilijk vervulbare vacatures bereikte een piek in de zomer van 20I2, maar daalde weer in de tweede helft van het jaar. Het percentage bedrijven met vacatures die 6-I2 maanden open staan steeg juist in de tweede helft van het jaar. Dit zou tot een nieuwe piek in langdurig openstaande vacatures kunnen leiden in de eerste helft van 2013.

Bedrijven wijten de wervingsproblemen voornamelijk aan een gebrek aan aanbod van sollicitanten, het ontbreken van de juiste competenties en onvoldoende werkervaring bij sollicitanten. De meest populaire interne aanpassingen die bedrijven in de Metalektro toepassen om met onvervulde vacatures om te gaan is om hun zittend personeel flexibeler in te zetten en/of overuren te laten dradien. Dit leidt ertoe dat een toegenomen werkdruk het meest ondervonden gevolg is van onvervulde vacatures, hoewel het percentage bedrijven dat hiermee te maken heeft in 2012 lager is dan in $20 I I$. 


\subsection{Daling in percentage bedrijven met vacatures}

Vacatures zijn een belangrijke indicator van de economische ontwikkeling van een land of sector. Voor de arbeidsmarktmonitor van 2012 hebben we tijdens twee metingen onderzocht hoeveel bedrijven in de Metalektro vacatures hadden en voor welke functiecategorieën; in juli 2012 en in januari 2013 tijdens respectievelijk de tweede en vierde kwartaalmeting. Figuur 3.I geeft per functiecategorie weer welk deel van de bedrijven op die momenten vacatures had. In voorgaande edities van de arbeidsmarktmonitor Metalektro werd eens per jaar naar de vacatures gevraagd. Tevens hebben wij in 2012 voor het eerst de functiecategorie 'Engineering en R\&D functies' onderscheiden. Deze functiecategorie speelt een belangrijke rol in de verdeling van de vacatures over de functies.

Figuur 3.1

Percentage bedrijven met vacatures, naar functiecategorie van de werknemer, 2010-2012

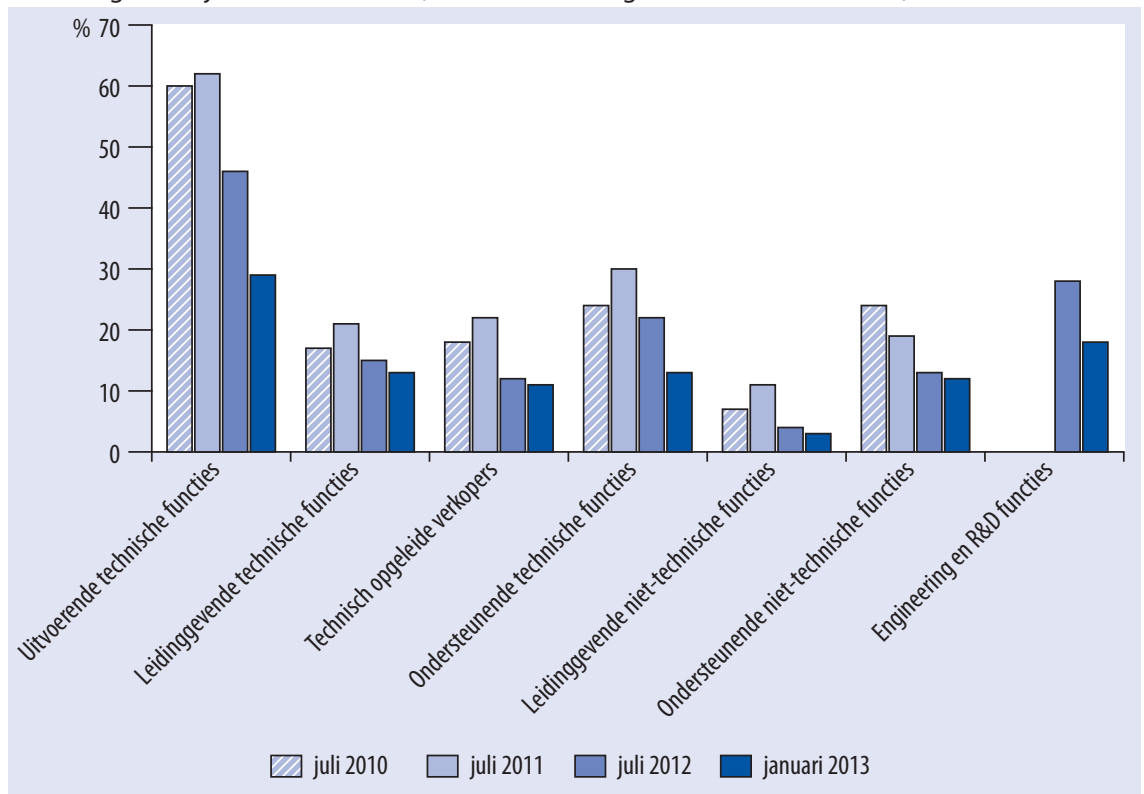

Bron: ROA, Arbeidsmarktmonitor Metalektro, 2010-2012

Waar in voorgaande jaren doorgaans de vraag naar ondersteunende technici de tweede plaats in nam -na op de eerste plaats de vraag naar uitvoerende technici- staat nu de vraag naar medewerkers voor engineering en R\&D functies meteen op de tweede plaats. De vraag naar uitvoerende technici is traditiegetrouw het grootst, met nog altijd 29 procent van de bedrijven die in januari 2013 aangeven vacatures te hebben voor deze functies. I8 procent van de bedrijven had op dat moment vacatures voor

5. In 2012 is de antwoordcategorie 'Engineering en R\&D functies voor het eerst opgenomen. Hierdoor kunnen verschuivingen in de andere categorieën zijn opgetreden. 
engineering en $\mathrm{R} \& \mathrm{D}$ functies, gevolgd door $\mathrm{I} 3$ procent van de bedrijven die vacatures hadden voor leidinggevende technische functies en ondersteunende technische functies. Het aandeel bedrijven met vacatures voor niet-technische leidinggevenden is zoals altijd het laagst.

Als we kijken naar de dynamiek van het aandeel bedrijven met vacatures in de afgelopen jaren, dan zien we dat de opleving van het percentage bedrijven met vacatures uit $201 \mathrm{I}$ helaas in 2012 geen stand heeft gehouden. Zowel in juli 2012 als in januari 2013 waren er voor alle functiecategorieën minder bedrijven met openstaande vacatures dan in 2010 en 201 . Gedurende het jaar 2012 is het aandeel bedrijven met vacatures dus voor alle functiecategorieën terug gelopen. In de anderhalf jaar die zijn verstreken tussen juli $201 \mathrm{I}$ en januari 2013 is het aandeel bedrijven met vacatures voor uitvoerende technici functies zelfs meer dan gehalveerd, van 62 tot 29 procent. Ook de percentages bedrijven met vacatures voor ondersteunende technische functies en vacatures voor leidinggevende niet-technische functies zijn meer dan gehalveerd in deze periode van anderhalf jaar. De teruggang in het aandeel bedrijven met vacatures voor leidinggevende technische functies is iets minder sterk. Dat geldt ook voor het aandeel bedrijven met vacatures voor ondersteunende niet-technische functies. Het aandeel bedrijven met vacatures voor technisch opgeleide verkopers is tussen juli $20 I I$ en januari 2013 precies gehalveerd.

Kijken we alleen naar de veranderingen in de tweede helft van het jaar 20I2, dan zien we dat de terugloop relatief het kleinst is voor de vraag naar technisch opgeleide verkopers en leidinggevenden. Doordat de vraag naar uitvoerende technici in de tweede helft van 2012 wel sterk is terug gelopen, was er aan het eind van het jaar verhoudingsgewijs nog nooit zoveel vraag naar technisch opgeleide verkopers ten opzichte van uitvoerende technici. Voor iedere technisch opgeleide verkoper zocht men in januari 2013 naar 'slechts' 2,6 uitvoerende technici, terwijl dit doorgaans rond de 3,5 is.

\subsection{Een nadere blik op vacatures: duur, functiecategorie, ontstaansreden en anticiperen}

\section{Meer moeilijk vervulbare vacatures in eerste helft 2012, minder in tweede helft van het jaar}

Dat het aandeel bedrijven met vacatures over de hele linie gedaald is in $2012 \mathrm{zou}$ erop kunnen wijzen dat er ook minder krapte is op de arbeidsmarkt. Om dat nader te onderzoeken kijken we in Figuur 3.2 naar de duur van openstaande vacatures voor technisch personeel. Dit levert een bijzonder beeld op. 
Figuur 3.2

Duur openstaande vacatures voor technisch personeel, 2009-2012

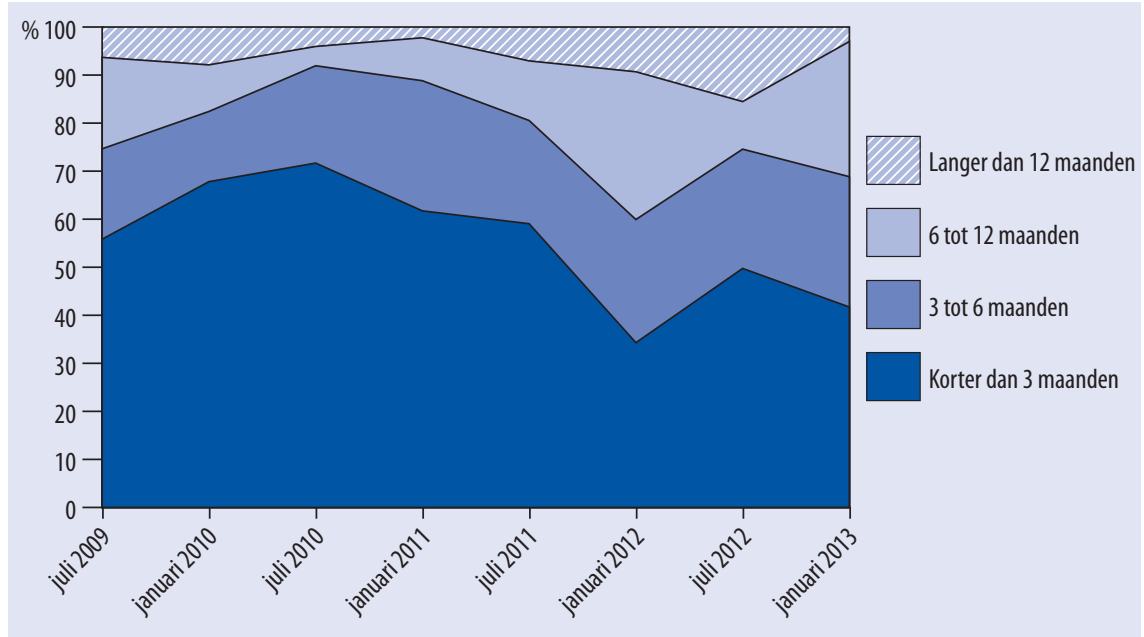

Bron: ROA, Arbeidsmarktmonitor Metalektro, 2009-2012

Ten eerste gaan we in op de eerste helft van 20I2. In de eerste helft van het jaar is het aantal vacatures dat kort ( $<3$ maanden) tot redelijk kort (3-6 maanden) open stond gestegen. Het percentage vacatures dat redelijk lang open stond (6-I2 maanden) is juist gedaald. Dat alles lijkt er op het eerste gezicht op te wijzen dat men in de eerste helft van 2012 relatief snel en gemakkelijk de geschikte kandidaten voor de vacatures wist te vinden. Tegelijkertijd zien we dat het percentage vacatures dat langer dan 12 maanden open stond in de eerste helft van 2012 is gegroeid. Deze ontwikkelingen zijn echter niet tegenstrijdig. We moeten dan een onderscheid maken tussen nieuw ontstane vacatures en reeds bestaande vacatures. In januari 2012 was de voorraad' vacatures die op dat moment al 6 tot 12 maanden open stond aanzienlijk. Een deel van deze vacatures is in de eerste helft van 2012 waarschijnlijk niet opgevuld en draagt daarmee bij aan het stijgende percentage vacatures in de eerste helft van 2012 dat langer dan I2 maanden open staat. Dit terwijl nieuw ontstane vacatures wel snel vervuld werden, gezien de stijgende aandelen voor vacatures die binnen 3 of binnen 3-6 maanden werden vervuld. Samenvattend kan worden gesteld dat metalektrobedrijven in de eerste helft van 2012 geworsteld hebben met een oude voorraad lastig te vervullen vacatures, terwijl nieuwe vacatures veel minder lastig te vervullen bleken.

In de tweede helft van 2012 tonen de cijfers het tegengestelde beeld van de eerste helft. Het aantal vacatures dat kort ( $<3$ maanden) of relatief kort (3-6 maanden) open stond daalt. Er zijn dus meer vacatures die langer nodig hebben om vervuld te worden, wat bijdraagt aan de stijging van het percentage vacatures dat 6 tot 12 maanden open staat. De voorraad moeilijk vervulbare vacatures lijkt eindelijk ook af te nemen want het percentage vacatures dat langer dan 12 maanden open staat daalt dan ook. Gezien de stijging in het aandeel vacatures dat in de tweede helft van 20126 tot 12 maanden 
open staat, zou het echter niet verwonderlijk zijn als er in de eerste helft van 2013 weer meer moeilijk vervulbare vacatures (I2+ maanden) blijken te zijn.

\section{Relatief minder vacatures voor uitvoerende technici, vraag naar $R \& D$ en engineering personeel in opkomst}

Figuur 3.I toonde het percentage bedrijven dat vacatures had naar functiecategorie, ongeacht het aantal vacatures. Daaruit bleek dat bedrijven het vaakst vacatures hebben voor uitvoerende technici. Figuur 3.3 toont ook een verdeling van vacatures naar functiecategorie, maar dit keer niet van bedrijven met vacatures, maar van het totale aantal vacatures die bedrijven hebben.

Figuur 3.3

Verdeling totaal aantal openstaande vacatures naar functiecategorie, 2012

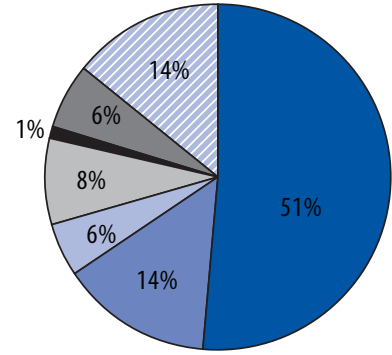

Juli 2012

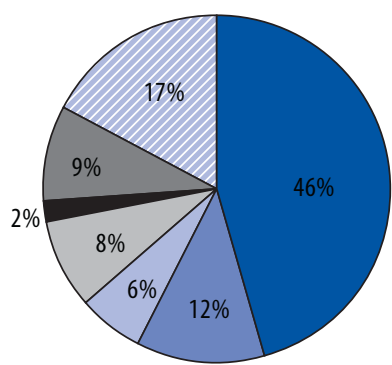

Januari 2013

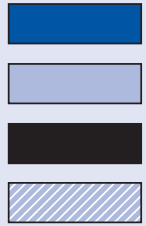

Uitvoerende technische functie

Technisch opgeleide verkopers

Leidinggevende niet-technische functies

Engineering en $R \& D$ functies

Bron: ROA, Arbeidsmarktmonitor Metalektro, 2012

Het beeld in Figuur 3.3 bevestigt het beeld uit Figuur 3.I, dat de vraag naar uitvoerende technici veruit het grootst is. Op peilmoment januari 2013 blijkt het aantal openstaande vacatures voor uitvoerende technici wel wat gedaald ten opzichte van juli 20I2. Deze daling van het aandeel vacatures voor uitvoerende technici in de tweede helft van 2012 is voornamelijk verschoven naar de engineering en R\&D functies, ondersteunende niet-technische functies en leidinggevende niet-technische functies, waarvoor het aandeel in het totaal aantal vacatures in de tweede helft van 2012 is toegenomen. 


\section{Ontstaansredenen van vacatures en mogelijkheden hierop te anticiperen}

Figuur 3.4 toont de ontstaansredenen van vacatures voor technici. In januari van 2012 stonden nog relatief veel vacatures open die ontstaan waren door een toename van de hoeveelheid werk, zeer waarschijnlijk als gevolg van de positieve omzetontwikkeling in de Metalektro in 2OII (zie Figuur I.2). In juli van 2012 stonden iets minder vaak vacatures open die waren ontstaan als gevolg van een toename van de hoeveelheid werk en in januari 2013 was het percentage vacatures dat om deze reden was ontstaan met $46 \%$ bijzonder laag. Dit is hoogstwaarschijnlijk veroorzaakt door de sterke afname in omzet in de tweede helft van 2012 (zie Figuur I.2). In de tweede helft van 2012 zijn relatief minder vacatures ontstaan door een toename van de hoeveelheid werk. Daarentegen zijn vacatures relatief vaker toe te schrijven aan personeel dat vrijwillig vertrekt, met (pre)pensioen gaat, intern doorstroomt of gedwongen vertrekt. Tot slot is het opvallend dat de enige ontstaansreden die tussen januari $20 \mathrm{I} 2$ en januari 2013 in belang toeneemt het gedwongen vertrek van personeel is.

\section{Figuur 3.4}

Ontstaansreden van vacatures voor technici, 2012

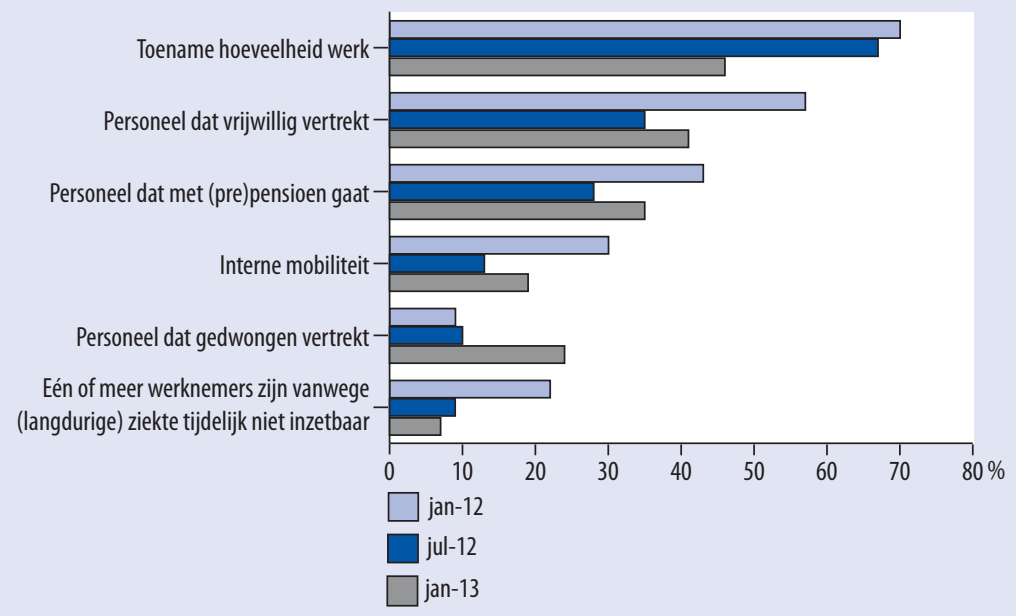

Bron: ROA, Arbeidsmarktmonitor Metalektro, 2012

Noot: De ontstaansredenen 'het tijdelijk niet inzetbaar zijn van één of meer werknemers om andere redenen dan ziekte' en 'het minder werken door één of meer werknemers' zijn eveneens als antwoordcategorie opgenomen, maar worden door minder dan $5 \%$ van de bedrijven genoemd.

Tijdens de metingen vragen we de deelnemende bedrijven onderscheid te maken tussen vacatures die zijn ontstaan naar aanleiding van een actueel personeelstekort (reactief) en vacatures die anticiperen op een toekomstig personeelstekort (pro-actief). Zoals Figuur 3.4 liet zien kunnen vacatures om verschillende redenen ontstaan. Sommige van deze ontstaansredenen kan men beter vooraf zien aankomen dan andere en daarop kan dan pro-actief ingespeeld worden. Figuur 3.5 laat zien op welke ontstaansredenen van vacatures bedrijven het beste pro-actief konden inspelen. 
Pensionering van personeel is iets wat doorgaans al geruime tijd van tevoren bekend is. Dit is dan ook in heel 2012 de ontstaansreden van vacatures waar het beste voortijdig op kon worden ingespeeld. In de tweede helft van 2012 zien we een toename in het percentage bedrijven dat vacatures open stelde om pro-actief in te spelen op medewerkers die door ziekte niet inzetbaar zijn. Ook waren er relatief meer bedrijven in staat te anticiperen op vrijwillig of gedwongen vertrek van personeel. Veel minder bedrijven waren in de tweede helft van het jaar in staat te anticiperen op interne mobiliteit van personeel. Figuur 3.4 toonde al een stijging van het percentage vacatures dat als gevolg van interne mobiliteit was ontstaan. Wellicht zijn deze interne verschuivingen plotseling ontstaan waardoor hierop minder goed kon worden geanticipeerd dan in de eerste helft van 2012.

\section{Figuur 3.5}

Bij welke ontstaansreden van vacatures voor technici zijn bedrijven het meest in staat pro-actief hierop in te spelen?

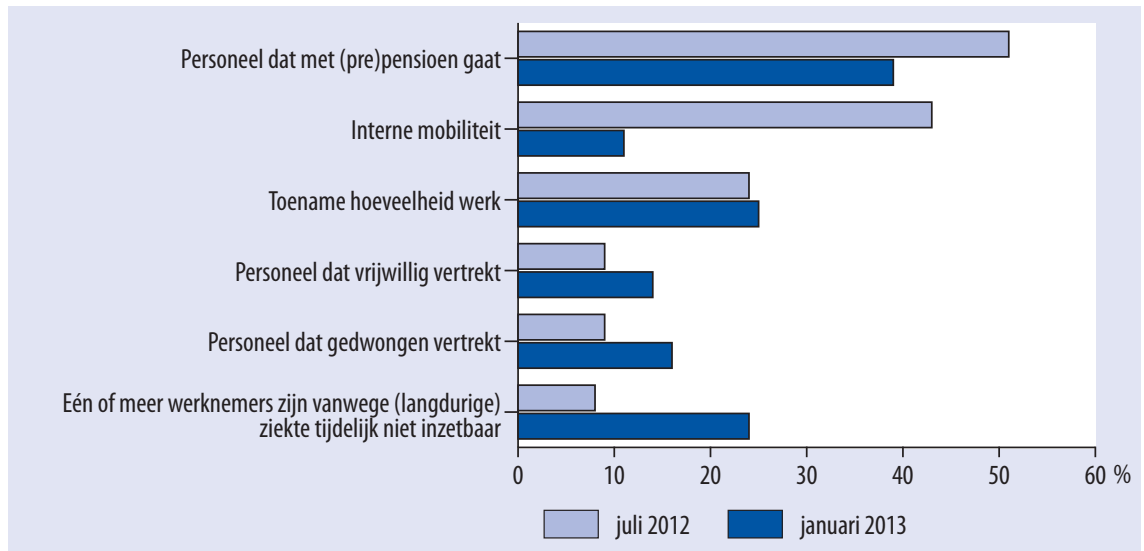

Bron: ROA, Arbeidsmarktmonitor Metalektro, 2012

Noot: De ontstaansredenen 'het tijdelijk niet inzetbaar zijn van één of meer werknemers om andere redenen dan ziekte 'en 'het minder werken door één of meer werknemers' zijn eveneens als antwoordcategorie opgenomen, maar worden door minder dan $5 \%$ van de bedrijven genoemd.

\subsection{Uitzendbureaus en commerciële werving en selectiebureaus zijn meest populaire wervingskanalen}

Zoveel verschillende typen functies en ontstaansredenen voor vacatures als er zijn, zoveel verschillende wervingskanalen bestaan er. In deze paragraaf gaan we in op de vraag welke van deze wervingskanalen door metalektrobedrijven als meest effectief worden beoordeeld en voor welke functies dit geldt. Figuur 3.6 laat zien welke wervingskanalen metalektrobedrijven als meest effectief beschouwen voor het invullen van vacatures voor uitvoerende en ondersteunende technici. Het uitzendbureau staat voor beide functiecategorieën duidelijk op de eerste plaats, op grote afstand gevolg 
door de overige wervingskanalen. De verschillen tussen deze overige wervingskanalen zijn maar klein, vergeleken met de grote voorkeur voor uitzendbureaus. De informele kanalen zijn voor beide functies het minst effectieve wervingskanaal.

\section{Figuur 3.6}

Meest effectieve wervingskanalen voor uitvoerende en ondersteunende technici (\% bedrijven), 2012

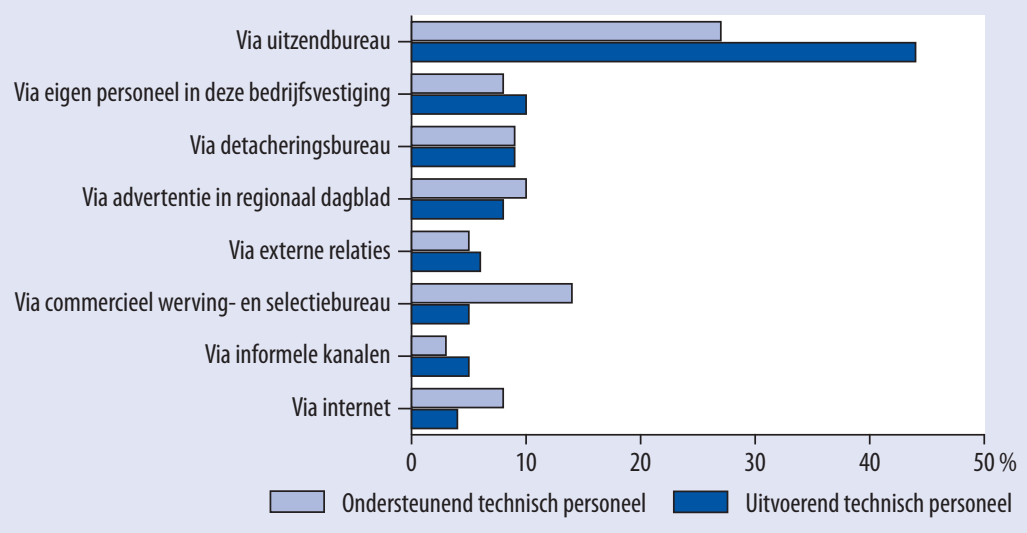

Bron: ROA, Arbeidsmarktmonitor Metalektro, 2012

Noot: De navolgende wervingskanalen zijn eveneens als antwoordcategorie opgenomen, maar worden door minder dan $5 \%$ van de bedrijven genoemd: advertenties in landelijke dagbladen, advertenties in vakbladen, open sollicitaties, via personeel in andere bedrijfsvestiging(en), UWV WERKbedrijf (voormalig CWI) en school/opleiding.

\section{Tekstbox 3.1 Wanneer worden uitzendbureaus in geschakeld?}

Klaas Trienekens (loopbaanadviseur) en Carlo Hurkmans, intercedent technisch personeel bij Randstad Techniek in Eindhoven, geven aan dat zij meestal door bedrijven worden ingeschakeld die zelf geen tijd hebben om naar geschikt personeel te zoeken. 0ok worden zij vaak ingeschakeld omdat er soms zoveel potentiële kandidaten op een vacature reageren dat de bedrijven door de bomen het bos niet meer zien. Randstad neemt dan de selectie voor haar rekening en maakt een overzicht van de meest interessante kandidaten. Daarnaast is Randstad ook betrokken bij de strategische personeelsplanning van bedrijven. Door gebruik te maken van inleen, opleiding van ingeleend personeel en opleiding van vast personeel van de bedrijven, zorgt Randstad voor nieuwe instroom en goede vakkrachten. Randstad Techniek wordt voor arbeidsbemiddeling voornamelijk door MKB bedrijven ingehuurd en daarbij is een duidelijke focus op bedrijven tot zo'n vijftig medewerkers. Grotere bedrijven maken doorgaans zelf menskracht beschikbaar voor het aantrekken en opleiden van personeel, volgens de heren Trienekens en Hurkmans.

In Figuur 3.7 kijken we naar de meest effectieve wervingskanalen voor leidinggevend technische personeel en technisch opgeleide verkopers. Hier komt een totaal ander beeld naar voren dan wat we zagen bij de uitvoerende en ondersteunende technici. Het uitzendbureau speelt nauwelijks een rol van betekenis bij de werving van leidinggevend technisch personeel en technisch opgeleide verkopers. Voor deze functiecategorieën staat werving via commerciële werving- en selectiebureaus stevig op de eerste 
plaats, op afstand gevolgd door internet en detacheringsbureaus. De overige wervingskanalen worden zelden als meest effectief beoordeeld.

\section{Figuur 3.7}

Meest effectieve wervingskanalen voor leidinggevend technisch personeel en technisch opgeleide verkopers (\% bedrijven), 2012

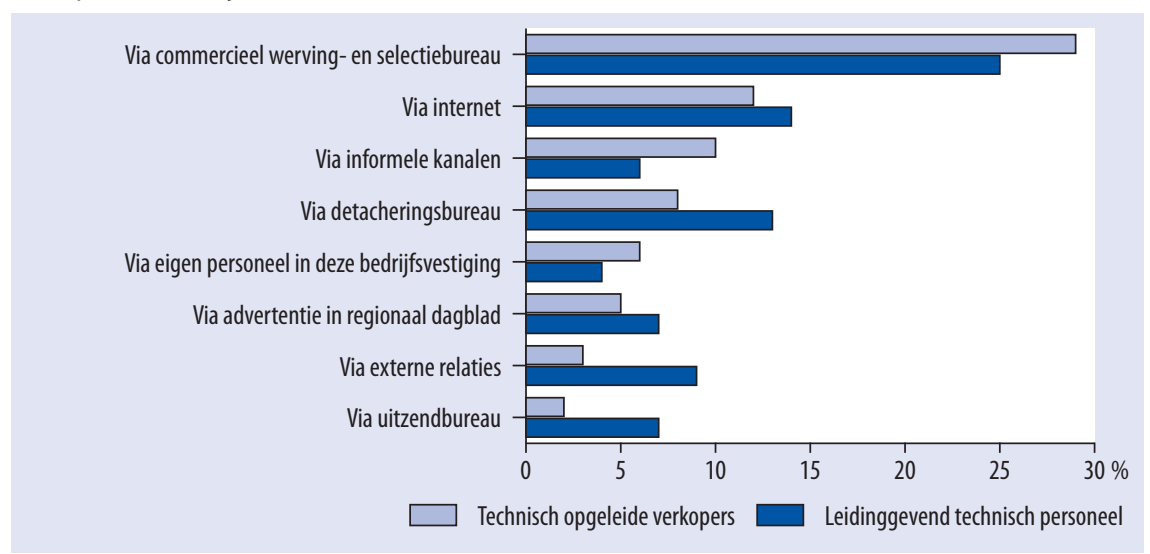

Bron: ROA, Arbeidsmarktmonitor Metalektro, 2012

Noot: De navolgende wervingskanalen zijn eveneens als antwoordcategorie opgenomen, maar worden door minder dan $5 \%$ van de bedrijven genoemd: via school/opleiding, UWV WERKbedrijf (voormalig CWI), via personeel in andere bedrijfsvestiging(en), advertenties in vakbladen, advertenties in landelijke dagbladen, en open sollicitaties.

Het internet is nog steeds een relatief nieuw wervingskanaal maar blijkt toch al een tweede plaats in te nemen als het gaat om werving voor leidinggevende technici en technisch opgeleide verkopers. Als we kijken hoe de effectiviteit van internet als wervingskanaal voor diverse functiecategorieën zich de afgelopen jaren heeft ontwikkeld (Figuur 3.8), dan zien we opmerkelijk genoeg sinds 2007 een dalende trend. Leidinggevend technisch personeel is de enige functiecategorie waarvoor in het afgelopen jaar een stijging te zien was in de effectiviteit van internet als wervingskanaal. Voor alle overige functiecategorieën daalt de effectiviteit van internet als wervingskanaal als sinds 2007, met slechts een korte opleving in 2010. 


\section{Figuur 3.8}

Internet als meest effectieve wervingskanaal genoemd, naar technische functiecategorie, 20072012

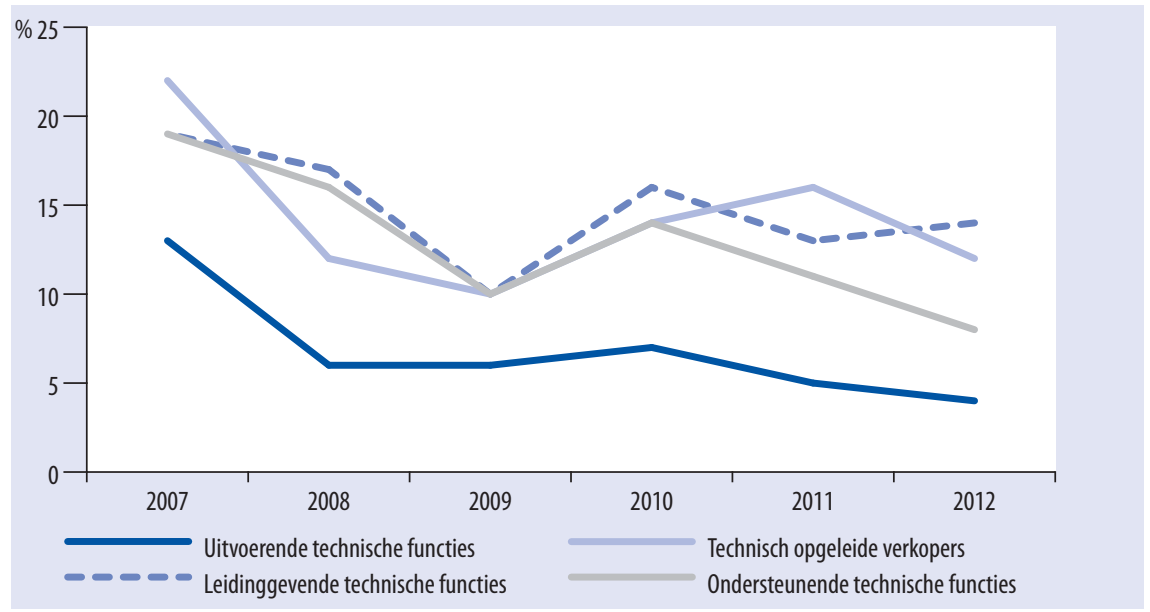

Bron: ROA, Arbeidsmarktmonitor Metalektro, 2007-2012

Metalektrobedrijven hebben dus uitgesproken voorkeuren als het gaat om wervingskanalen voor verschillende functiecategorieën. De twee wervingskanalen die met afstand bovenaan staan in hun functiecategorieën zijn uitzendbureaus en commerciële werving- en selectiebureaus. De rol van internet lijkt sinds 2007 te dalen op enkele tijdelijke oplevingen na. Dankzij internet kennen we tegenwoordig wel de zogeheten social media, die misschien wel een steeds belangrijker wervingsinstrument kunnen worden. Tekstbox 3.2 geeft hiervan een voorbeeld.

\section{Tekstbox 3.2 Werving en selectie via social media bij NedTrain TechniekFabriek}

In 2012 is NedTrain gestart met hun bedrijfsschool de TechniekFabriek. Werving en selectie van instromers gebeurt niet via traditionele kanalen, maar via social media. Hoewel het hier gaat om werving en selectie voor instroom in een bedrijfsschool en niet zozeer om een traditionele vacature, biedt dit wellicht ook inspiratie voor andere bedrijven die ook jongeren proberen te werven. Koen Sueters, manager van de NedTrain TechniekFabriek zegt over hun strategie: "Werving en selectie voor de doelgroep leerlingen waar het hier om gaat doet NedTrain via social media. Op de communicatieafdeling wordt echt nagedacht over wervingsteksten die in 140 tekens passen! Een banenmarkt bezoeken is voor deze doelgroep volstrekt kansloos, daar komen geen jongeren. Je moet weten hoe de nieuwe generatie denkt en werkt en dit faciliteren." 


\subsection{2 was een jaar van uitersten: bedrijven hebben zeer veel of juist zeer weinig wervingsproblemen}

In 2012 was het (dreigend) tekort aan goed opgeleid technisch personeel een veel besproken thema. Dit zou tot uiting kunnen komen in de mate waarin bedrijven problemen ondervinden bij het aantrekken van technisch personeel. Figuur 3.9 geeft aan hoeveel problemen bedrijven in de Metalektro in de afgelopen jaren hebben ervaren bij het vinden van technisch personeel.

Figuur 3.9

Percentage bedrijven naar problemen bij het vinden van technisch personeel, 2007-2012

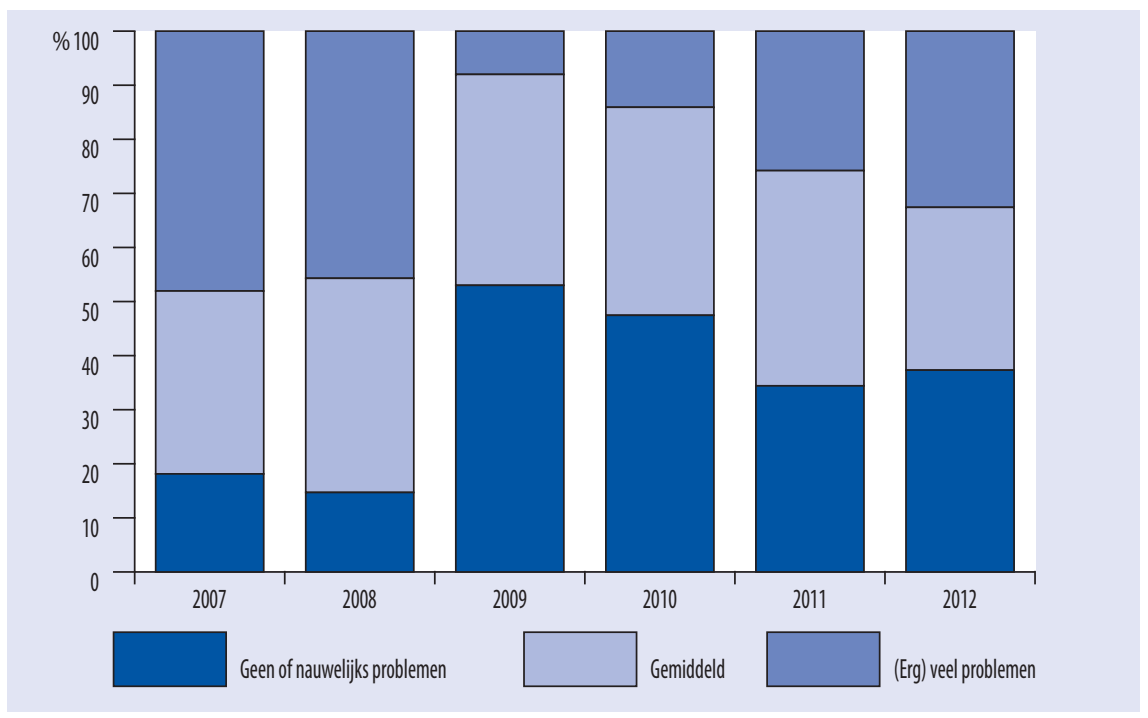

Bron: ROA, Arbeidsmarktmonitor Metalektro, 2007-2012

In 2007 en 2008, de jaren voordat de huidige economische crisis in alle hevigheid los barstte, had bijna de helft van de bedrijven veel tot erg veel problemen bij het vinden van technisch personeel. Toen de crisis in 2009 in volle gang was daalde het aandeel bedrijven met erg veel problemen bij het vinden van technisch personeel tot minder dan tien procent. $\mathrm{Na} 2009$ is het aantal bedrijven dat hierbij erg veel problemen ondervindt echter weer sterk gegroeid tot meer dan 30 procent van alle metalektrobedrijven in 20I2. Deze stijging gaat tussen 2009 en $201 \mathrm{I}$ ten koste van het percentage bedrijven dat hierbij geen of nauwelijks problemen ondervindt, wat daalde van $54 \%$ in 2009 to $34 \%$ van alle bedrijven in 20II. In 2012 is het percentage bedrijven zonder wervingsproblemen echter weer iets gestegen tot $37 \%$. Het percentage bedrijven dat aangeeft 'gemiddeld' (niet weinig en niet veel) problemen te ervaren bij de werving van technici is tot en met $201 \mathrm{I}$ redelijk stabiel rond de 40 procent. Echter, in Figuur 3.9 is duidelijk te zien dat het percentage bedrijven dat 'gemiddeld' problemen ondervond bij het aantrekken van technici in 2012 afneemt tot $30 \%$, doordat er zowel meer 
bedrijven zijn die veel, dan wel weinig wervingsproblemen ondervinden. Dit maakt 2012 tot een jaar waarin de extremen domineren: een groot deel van de bedrijven heeft niet of nauwelijks problemen om technici te werven en een bijna even groot deel heeft (erg) veel problemen hiermee.

In de Figuren 3.Io en 3.II gaan we dieper in op die bedrijven die aan hebben gegeven 'gemiddeld', veel of erg veel problemen te hebben bij het vinden van technisch personeel. Omdat 'technisch personeel' een breed begrip is laat Figuur 3.IO zien hoeveel procent van de hierboven gedefinieerde groep bedrijven wervingsproblemen ondervindt uitgesplitst naar vier typen technische functies. In Figuur 3.II splitsen we dit voor 2012 verder uit naar regio. Uit Figuur 3.Io blijkt dat de uitvoerende technische functies al jaren het meeste voor wervingsproblemen te zorgen. Ondanks een dalende trend voor deze functiecategorie, geeft nog altijd $60 \%$ van de bedrijven aan problemen te hebben gehad om aan uitvoerende technici te komen. Wat verder opvalt is de stijging van het percentage bedrijven die aangeven dat ze problemen hebben gehad bij het werven voor ondersteunende technische functies. Figuur 3.II laat zien dat de verschillen in de wervingsproblematiek tussen de regio's Zuid en West bijzonder klein zijn. Het meest opvallend is dat de wervingsproblemen in regio Noord/Oost veel vaker dan in de andere regio's betrekking hebben op ondersteunende technici en minder op uitvoerende technici.

\section{Figuur 3.10}

Percentage bedrijven met problemen bij het vinden van technisch personeel, naar functiecategorie van de werknemer, 2007-2012

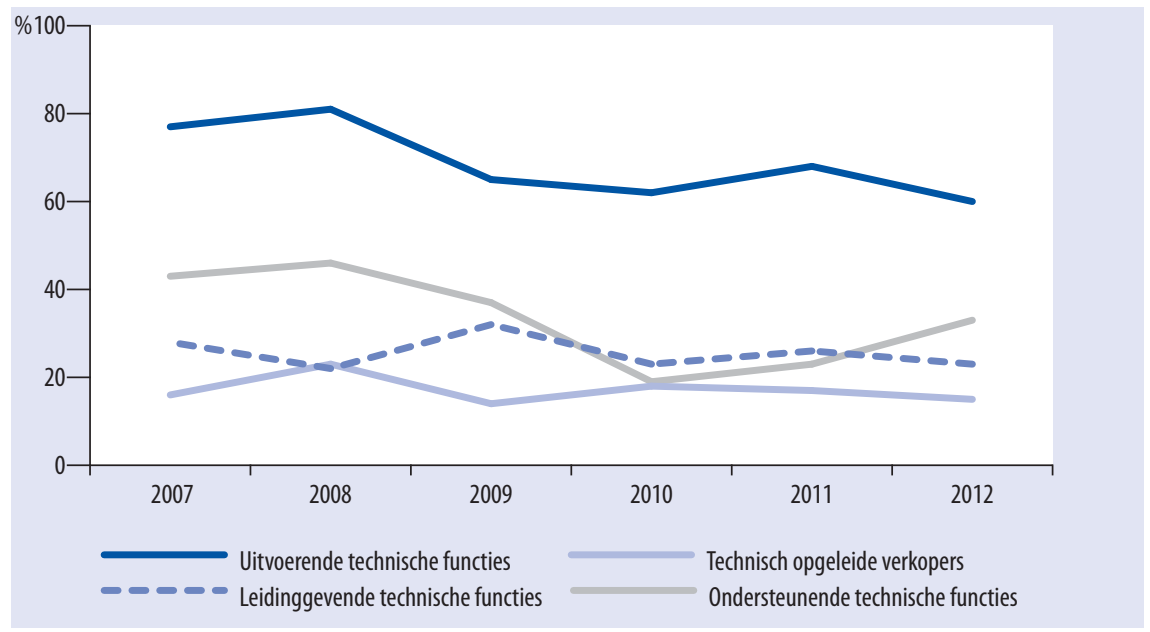

Bron: ROA, Arbeidsmarktmonitor Metalektro, 2007-2012 


\section{Figuur 3.11}

Percentage bedrijven met problemen bij het vinden van technisch personeel per regio, naar beroepscategorie van de werknemer, 2012

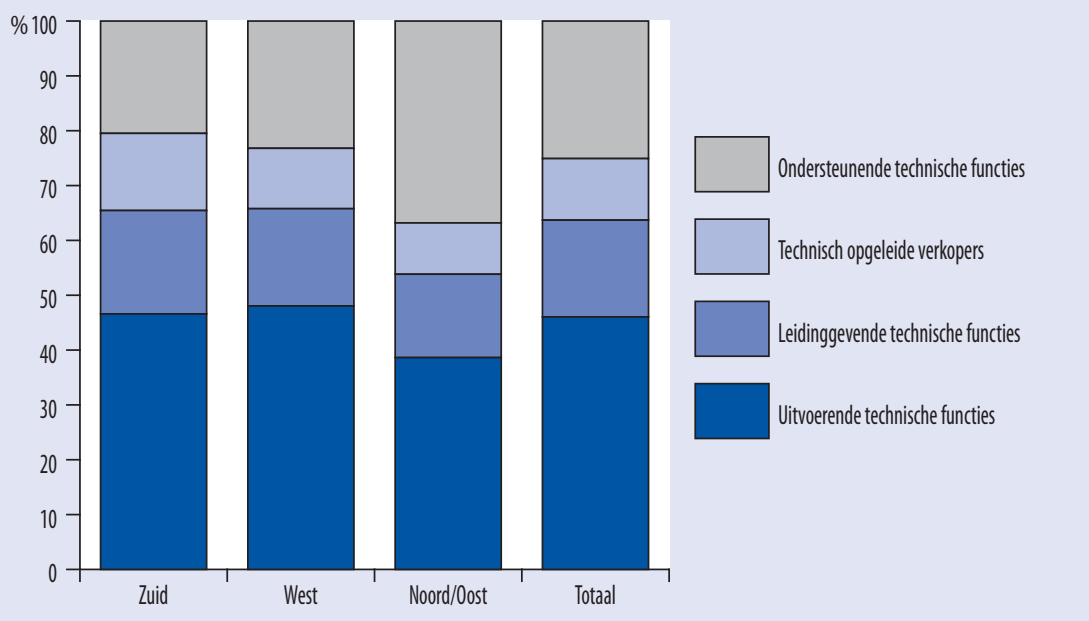

Bron: ROA Arbeidsmarktmonitor Metalektro, 2012

De bovenstaande drie figuren geven een goed beeld van de omvang en richting van de wervingsproblemen voor technici. De volgende figuren gaan in op de oorzaken en gevolgen van de wervingsproblemen alsmede op de maatregelen die de bedrijven nemen om de wervingsproblemen te beperken. Figuur 3.I2 toont wat metalektrobedrijven vanaf 20 Io als de belangrijkste oorzaken voor de wervingsproblemen zien. Al jaren blijkt het grootste probleem te zijn dat sollicitanten niet de juiste competenties hebben. Ook een tekortschietend aanbod van sollicitanten en een gebrek aan werkervaring bij sollicitanten worden door veel bedrijven genoemd als oorzaak voor hun wervingsproblemen. We zien sinds 2010 een lichte stijging in het percentage bedrijven dat aangeeft dat er te weinig aanbod vanuit de opleidingen komt en ook een sterke stijging van het percentage bedrijven dat aangeeft dat er te weinig mensen zijn met interesse in een technisch beroep. Deze twee ontwikkelingen bieden ondersteuning aan de al jaren klinkende roep om meer mensen te interesseren voor technische opleidingen en beroepen. 
Figuur 3.12

Belangrijkste oorzaken van de wervingsproblemen voor technisch personeel, 2010-2012

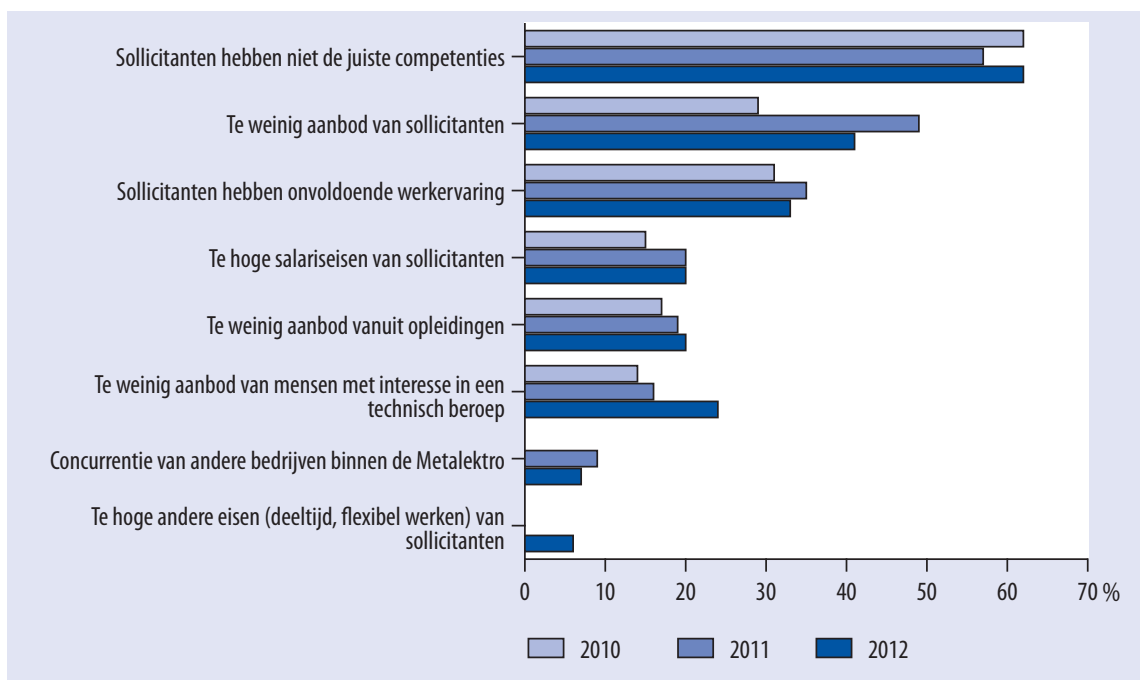

Bron: ROA, Arbeidsmarktmonitor Metalektro, 2010-2012

Noot: 'Concurrentie van andere bedrijven buiten de Metalektro' is eveneens als antwoordcategorie opgenomen, maar wordt door minder dan 5\% van de bedrijven genoemd. Voor het eerst is in 2012 ook de antwoordcategorie opgenomen dat sollicitanten te hoge andere eisen stellen (buiten salaris). Dit wordt door slechts $6 \%$ van de bedrijven genoemd als probleem bij de werving van technisch personeel.

De problemen die bedrijven ondervinden bij het werven van technici leiden ertoe dat een niet gering aantal vacatures voor langere tijd onvervuld blijft (zie paragraaf 3.2). Daarnaast toonde Figuur 3.9 dat 63\% van de metalektrobedrijven in 2012 in gemiddeld of veel problemen had bij het vinden van technisch personeel. Tabel 3.I laat zien wat in de jaren 20IO-20I2 de meest voorkomende gevolgen zijn van niet-ingevulde vacatures. De tabel laat duidelijk zien dat personeelstekorten veel schadelijke gevolgen hebben voor de metalektrobedrijven. Toegenomen werkdruk staat al jaren stevig op de eerste plaats van gevolgen van niet-ingevulde vacatures en wordt in 2012 door $70 \%$ van de bedrijven genoemd (in $201 \mathrm{I}$ nog door $88 \%$ ). Op de tweede plaats staat werk dat blijft liggen/gemiste deadlines, wat door $47 \%$ van de bedrijven wordt genoemd. Op de derde plaats staat sinds twee jaar dat niet-ingevulde vacatures leiden tot hogere kosten doordat werk moet worden uitbesteed. Daarnaast leidden niet-ingevulde vacatures in 2012 tot een verlies aan orders (4e plaats) en een vermindering van de kwaliteit van de productie (se plaats). 
Tabel 3.1

Top 5 gevolgen van niet-ingevulde vacatures voor bedrijven die met niet-ingevulde vacatures te maken hebben, 2010-2012

\begin{tabular}{|c|c|c|c|}
\hline & 2010 & 2011 & 2012 \\
\hline 1 & Toegenomen werkdruk (79\%) & Toegenomen werkdruk (88\%) & $\begin{array}{l}\text { Toegenomen } \\
\text { werkdruk (70\%) }\end{array}$ \\
\hline 2 & $\begin{array}{l}\text { Werk blijft liggen/deadlines } \\
\text { gemist (47\%) }\end{array}$ & $\begin{array}{l}\text { Werk blijft liggen/deadlines } \\
\text { gemist ( } 45 \%)\end{array}$ & $\begin{array}{l}\text { Werk blijft liggen/ } \\
\text { deadlines gemist } \\
(47 \%)\end{array}$ \\
\hline 3 & $\begin{array}{l}\text { Levertijden worden langer } \\
(31 \%)\end{array}$ & $\begin{array}{l}\text { Hogere kosten doordat werk } \\
\text { moet worden uitbesteed } \\
(29 \%)\end{array}$ & $\begin{array}{l}\text { Hogere kosten } \\
\text { doordat werk moet } \\
\text { worden uitbesteed } \\
(28 \%)\end{array}$ \\
\hline 4 & Verlies aan orders (21\%) & $\begin{array}{l}\text { Hogere wervings- of } \\
\text { opleidingskosten (24\%) }\end{array}$ & $\begin{array}{l}\text { Verlies aan orders } \\
(25 \%)\end{array}$ \\
\hline 5 & $\begin{array}{l}\text { Vermindering van de } \\
\text { kwaliteit van de productie } \\
(16 \%) / \text { Hogere kosten doordat } \\
\text { werk moet worden uitbesteed } \\
(16 \%)\end{array}$ & $\begin{array}{l}\text { Levertijden worden langer } \\
(20 \%)\end{array}$ & $\begin{array}{l}\text { Vermindering van } \\
\text { de kwaliteit van de } \\
\text { productie }(22 \%)\end{array}$ \\
\hline
\end{tabular}

De percentages in de top 5 tellen binnen een jaar niet op tot Ioo\%. Dat betekent dat veel bedrijven aangeven dat ze meerdere van deze gevolgen van niet-ingevulde vacatures gelijktijdig ondervinden. Dat maakt de noodzaak des te groter om zoveel mogelijk maatregelen te treffen om dit wervingsprobleem te verminderen. Welke aanpassingen in werving en selectie bedrijven het meeste maken en of deze aanpassingen als effectief worden beschouwd is af te lezen uit Figuur 3.13. Op de horizontale as is te zien welk percentage bedrijven een bepaalde aanpassing toepast. Anders dan in de jaarrapportage van vorig jaar, is dit jaar op de verticale as te zien welk percentage van de bedrijven die een bepaalde aanpassing toepassen, dit als (zeer) effectief beschouwen. 


\section{Figuur 3.13}

Percentage bedrijven naar aanpassingen in werving en selectie om met moeilijk vervulbare vacatures voor technisch personeel om te gaan, 2012

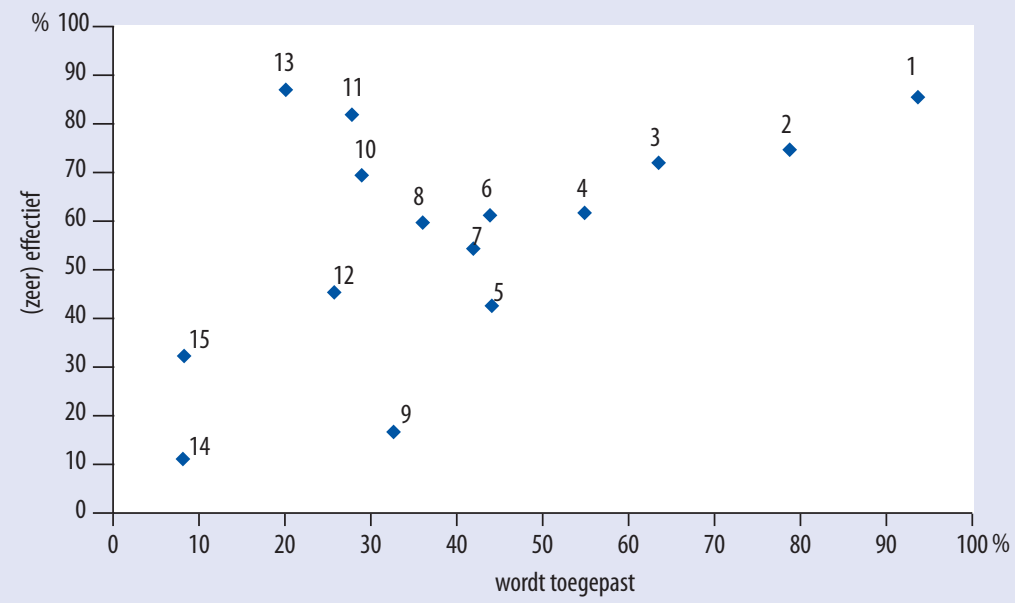

1. Inschakelen uitzend-, commerciële werving- en selectie- of detacheringsbureaus;

2. Aantrekken van mensen met minder ervaring

3. Bieden van goede loopbaanperspectieven;

4. Scholieren actiever benaderen;

5. Wervingsbonus voor het eigen personeel;

6. Aantrekken van anders opgeleiden (andere richting);

7. Aantrekken van lager opgeleiden (lager niveau);

8. Werven in het buitenland;

9. Inschakelen UWV WERKbedrijf (voormalig: (WI);

10. Competentiegericht werven;

11. Bieden van betere, $\mathrm{CAO}$ overstijgende arbeidsvoorwaarden;

12. Bieden van hoger salaris;

13. Collegiaal inlenen van personeel;

14. Inschakelen bureau voor arbeidsmarktcommunicatie;

15. Actiever benaderen van gedeeltelijk arbeidsongeschikten.

Bron: ROA, Arbeidsmarktmonitor Metalektro, 2012

Noot: Mogelijke aanpassingen, gerangschikt naar meest toegepast (horizontale as)

Het inschakelen van professionele externe ondersteuning in de vorm van uitzendbureaus, commerciële werving- en selectiebureaus en detacheringsbureaus wordt het meeste toegepast. Tachtig procent van de bedrijven die deze bureaus inschakelen vinden dit een effectieve aanpak. Op de tweede plaats komt het aantrekken van mensen met minder ervaring, wat door $77 \%$ van de bedrijven wordt gedaan en door bijna zeventig procent daarvan ook als effectief wordt beoordeeld. Het bieden van goede loopbaanperspectieven en het actiever benaderen van scholieren wordt door respectievelijk 62 en 54 procent van de bedrijven toegepast en door 67 en 58 procent van de bedrijven die dit doen effectief bevonden. De andere mogelijke aanpassingen aan het werving en selectiebeleid worden door minder dan de helft van de bedrijven toegepast. Dit is opmerkelijk omdat daar een aantal maatregelen bij zit die door de bedrijven die dit wél toepassen als effectief wordt beschouwd. 
Bijvoorbeeld het aantrekken van werknemers die een andere opleidingsrichting hebben dan eigenlijk werd gevraagd (punt 6). Dit wordt door $43 \%$ van de bedrijven toegepast en daarvan vindt $57 \%$ dit effectief of zeer effectief. $40 \%$ van de bedrijven trekt medewerkers met een lager niveau aan dan ze eigenlijk wilden en meer dan de helft daarvan vindt dit een effectieve of zeer effectieve methode om moeilijk vervulbare vacatures in te vullen. Het bieden van cao overstijgende arbeidsvoorwaarden is iets wat door 'slechts' $26 \%$ van de bedrijven wordt toegepast en staat daarmee op plaats II van I5. Toch wordt dit door ruim driekwart van de bedrijven die dit doen als effectief gezien. Dit is een hoge score op effectiviteit, maar wellicht dat het bieden van cao overstijgende arbeidsvoorwaarden financieel voor weinig bedrijven is weggelegd en dat deze maatregelen daardoor zo weinig worden toegepast. Ondanks dat, wijst dit erop dat met bovengemiddelde arbeidsvoorwaarden effectief geworven kan worden. Met welke arbeidsvoorwaarden deze bedrijven zich dan differentiëren is niet bekend, maar het gaat hier niet om het bieden van een hoger salaris, dat als aparte maatregel (punt I2) is opgenomen, maar minder wordt toegepast en ook minder effectief wordt gevonden. Dit wijst er op dat de cao overstijgende arbeidsvoorwaarden waarmee een deel van de bedrijven zo'n goede ervaringen hebben niet op salaris maar op andere voorwaarden betrekking hebben. Een andere maatregel die door weinig bedrijven wordt toegepast (I8\%) maar door $8 \mathrm{I} \%$ van die bedrijven effectief wordt gevonden, is het collegiaal inlenen van personeel. Dit is de hoogste effectiviteitsscore van alle maatregelen, maar vermoedelijk is het in de praktijk moeilijk om personeel collegiaal in te lenen, waardoor het maar weinig wordt toegepast. Maatregelen zoals het inschakelen van een bureau voor arbeidsmarktcommunicatie of het werven onder gedeeltelijk arbeidsongeschikten worden weinig toegepast en als ze worden toegepast maar door weinig bedrijven effectief gevonden. Het laatste opvallende punt is dat weliswaar een derde van de bedrijven het UWV inschakelt, maar dat dit door slechts $16 \%$ van die bedrijven effectief wordt gevonden. 


\section{Figuur 3.14}

Percentage bedrijven met interne aanpassingen om met moeilijk vervulbare vacatures voor technisch personeel om te gaan, 2012

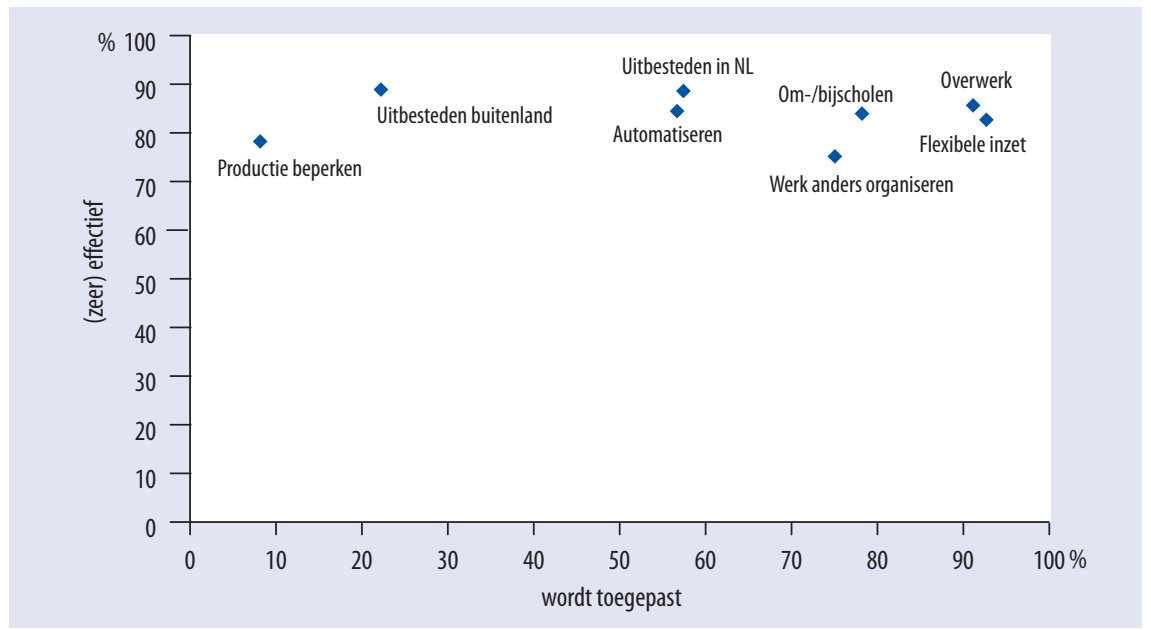

Bron: ROA, Arbeidsmarktmonitor Metalektro, 2012

Los van de aanpassingen die bedrijven in hun wervings- en selectiebeleid kunnen doorvoeren om het hoofd te bieden aan moeilijk vervulbare vacatures, kunnen ze ook ervoor kiezen om de interne bedrijfsvoering aan te passen aan het personeelstekort. Figuur 3.I4 toont hoeveel procent van de bedrijven met wervingsproblemen gebruik maken van de genoemde interne aanpassingen (horizontale as) en hoeveel procent van de bedrijven die zo'n aanpassing toepast, deze aanpassing als (zeer) effectief beschouwt. Alle maatregelen, of ze nou veel of weinig worden toegepast, worden in hoge mate als effectief beschouwd door de bedrijven die ze toepassen. Dit varieert van $75 \%$ voor de maatregelen 'aanpassen van de organisatie van het werk' tot $89 \%$ voor het uitbesteden van het werk binnen Nederland. Alle andere maatregelen zitten daar qua effectiviteit tussen. Gezien deze relatief kleine verschillen in effectiviteit, is het vooral interessant te kijken naar welke maatregelen het meeste worden toegepast. De meeste bedrijven proberen hun personeelstekorten op te vangen door flexibele inzet van het huidige personeel en overwerk, maar ook het om of bijscholen van huidige werknemers wordt door bijna $80 \%$ van de bedrijven genoemd en het anders organiseren van het werk door driekwart van de bedrijven. Daarna volgen automatiseren en het uitbesteden van werk binnen Nederland die door bijna 60\% van de bedrijven worden toegepast. Hekkensluiters zijn uitbesteden naar het buitenland en het beperken van de productie. Weinig bedrijven doen dit. Dit zijn vermoedelijk ook veel meer ingrijpende maatregelen dan de overige. 


\section{Competenties en opleidingsinspanningen}

In procenten van de totale loonsom, zijn metalektrobedrijven de laatste jaren minder uit gaan geven aan opleiding en training. In 2012 bedroeg dit gemiddeld $1,3 \%$. Trainingsuitgaven komen voor het grootste deel ten gunste van het personeel met een vaste aanstelling. Werkgevers lijken in 2012 met name bezuinigd te hebben op de trainingsdeelname van personeel met een tijdelijk dienstverband. Technici met een vaste aanstelling of die ingeleend werden ontvingen in 2012 juist iets vaker training dan in 20II. Trainingen zijn doorgaans vooral vaktechnisch gericht en worden in eerste instantie gevolgd met het oog op de uitoefening van de huidige functie. Het initiatief tot deelname aan de trainingen wordt veelal genomen door de direct leidinggevende of de beslissing om een training te gaan volgen vindt in onderling overleg plaats. Het komt echter nauwelijks vanuit de werknemer zelf.

Om de eigen betrokkenheid van werknemers bij hun competentieontwikkeling te vergroten, kaarten werkgevers dit vooral aan tijdens functioneringsgesprekken en proberen ze dit daarnaast door coachend leiderschap te stimuleren. De grootste belemmeringen die het opleiden van technici in de weg kunnen staan zijn tijd- en geldgebrek, maar er zijn ook veel werkgevers die op dit punt helemaal geen belemmeringen ervaren. Het niveau van de interne mobiliteit is in 2012 ongewijzigd gebleven. Verder wordt er de laatste jaren een toename waargenomen in het gebruik van diverse 'softere' instrumenten (gespreksvormen zoals bijvoorbeeld functioneringsgesprekken) die het loopbaanmanagement naar een hoger niveau moeten tillen, terwijl juist minder gebruik wordt gemaakt van de meer concrete HR-instrumenten. 


\subsection{Trainingsinspanningen}

Minder training voor tijdelijke medewerkers, training voor vast personeel zeer licht gestegen

Wanneer het trainen van werknemers wordt gezien als investering in menselijk kapitaal, dan zal een werkgever doorgaans eerder geneigd zijn om te investeren in medewerkers waarvoor de kans het grootst is dat de werkgever zijn investeringen kan terugverdienen. Dit betekent dat een werkgever met het oog op de terugverdientijd eerder in de ontwikkeling van een werknemer met een vaste aanstelling zal investeren dan in een werknemer met een tijdelijke aanstelling. Verder zal diezelfde werkgever vaker investeren in de ontwikkeling van zijn medewerkers als deze een tijdelijke aanstelling hebben dan dat deze worden ingeleend bij bijvoorbeeld uitzend- of detacheringsbureaus. Om deze theorie in de praktijk te kunnen testen wordt sinds 20 oro aan het werkgeverspanel gevraagd naar de trainings- en cursusdeelname van het technisch personeel per type dienstverband. Hiermee wordt bedoeld dat zij in het betreffende jaar minimaal één cursus of training hebben gevolgd. Dit betekent dat informeel leren, i.e. learning on the job, hier buiten beschouwing wordt gelaten.

Figuur 4.I geeft voor de periode 20IO-20I2 weer welk deel van het technisch personeel getraind werd. Evenals in de jaren ervoor, hebben werkgevers in 2012 vooral geïnvesteerd in technisch personeel met een vaste aanstelling. Volgens de werkgevers heeft in 2012 gemiddeld bijna de helft van het technisch personeel met een vaste aanstelling minimaal één cursus of training gevolgd. Dit is een lichte toename ten opzichte van $201 \mathrm{I}$ (+2\%-punt), maar nog altijd lager dan in 20 Io toen bijna zes op de Io technici met een vaste aanstelling getraind werden. Opvallend is dat werkgevers in 2012 met name bezuinigd lijken te hebben op de trainingsdeelname van het technisch personeel in tijdelijke loondienst. Terwijl in 2010 en 201 nog een kwart van het technisch personeel met een tijdelijk contract getraind werd, blijkt uit de figuur dat dit in 2012 behoorlijk is afgenomen (-7\%-punt). In 2012 volgde nog I $6 \%$ van deze tijdelijke arbeidskrachten minimaal één cursus of training. Deze afname van de trainingsdeelname van het technisch personeel in tijdelijke loondienst is vrijwel volledig toe te schrijven aan een sterke daling in West-Nederland. In 20 II volgde $30 \%$ van de technici in tijdelijke loondienst in het westen van het land minimaal één cursus of training en in 2012 nam dit met II\%-punt af tot $19 \%$.

De trainingsdeelname van oproepkrachten, uitzendkrachten en gedetacheerden is zoals verwacht het laagst van alle typen dienstverbanden. De trainingsdeelname onder ingeleende medewerkers in de jaren 20IO-20I2 verloopt volgens een zelfde patroon als onder vaste medewerkers. Voor beide groepen geldt namelijk dat de trainingsdeelname al in $201 \mathrm{I}$ was teruggeschroefd. In 2012 vindt er een zeer lichte stijging plaats (+I\%-punt) en wordt $7 \%$ van de medewerkers die door metalektrobedrijven worden ingeleend getraind. Dat metalektrobedrijven weinig investeren in de trainingsdeelname van ingeleend personeel is logisch als men weet dat metalektrobedrijven rede- 
lijk tevreden zijn over de aandacht die uitzend- en detacheringsbureaus zelf besteden aan het op peil houden van de competenties van flexwerkers. Dit bleek uit een van de stellingen die in 2012 in de arbeidsmarktmonitor aan de metalektrobedrijven is voorgelegd. ${ }^{6}$

\section{Figuur 4.1}

Gemiddelde trainings- en cursusdeelname van technisch personeel (\%) naar type dienstverband, 2010-2012

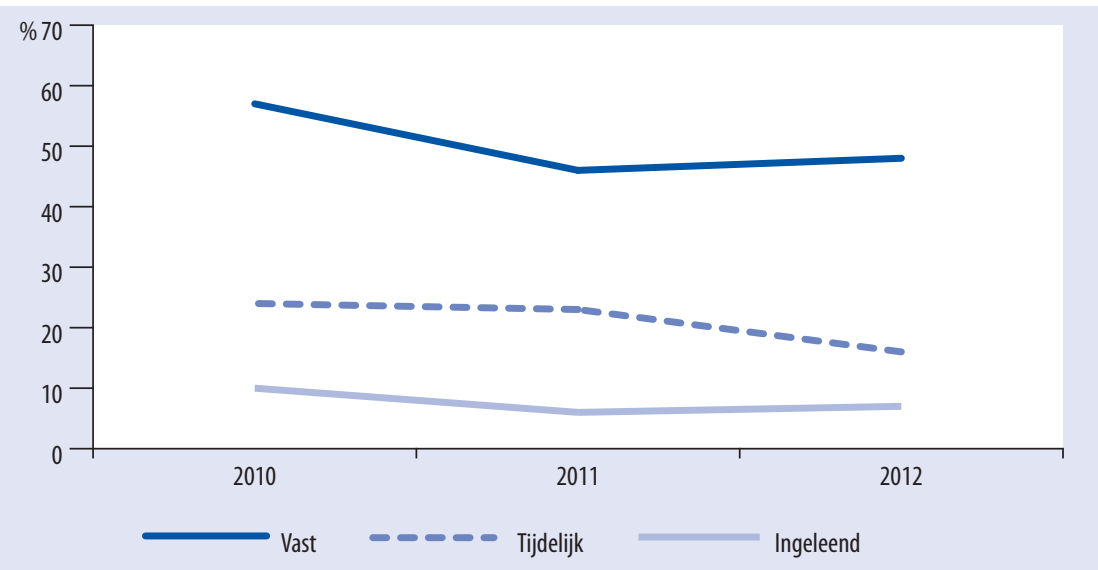

Bron: ROA, Arbeidsmarktmonitor Metalektro, 2010-2012

\section{Regionale verschillen: regio Noord/Oost blijft achter bij West en Zuid}

Figuur 4.2 geeft per regio de trainingsdeelname in 2012 weer van technisch geschoolde medewerkers naar contractvorm. Dit is een regionale uitsplitsing van de totale percentages voor trainingsdeelname in 2012 uit Figuur 4.I. Uit de figuur blijkt dat er in 2012 behoorlijke regionale verschillen bestaan met betrekking tot de trainingsdeelname van het technisch personeel. De regio Noord/Oost blijft qua trainingsdeelname van technisch personeel met een vaste of tijdelijke aanstelling achter bij de regio's West en Zuid. In de regio Noord/Oost wordt 35\% van het technisch personeel met een vast dienstverband getraind, terwijl dit in de regio's Zuid en West respectievelijk 55\% en $50 \%$ is. Verder blijkt dat in de regio Noord/Oost in 2012 gemiddeld IO\% van het technisch personeel in tijdelijke loondienst minimaal één cursus of training heeft gevolgd, terwijl dit in beide andere regio's bijna twee keer zoveel was. De trainingsdeelname van ingeleende technici bevindt zich in alle drie de regio's op een vergelijkbaar laag niveau.

6. Zie voor uitgebreide informatie de Quickscan van januari 20I3: http://www.ao-metalektro.nl/cms/publish/content/downloaddocument.asp?document_id=53I 


\section{Figuur 4.2}

Technisch personeel (\%) dat minimaal één cursus of training heeft gevolgd naar type dienstverband en regio, 2012

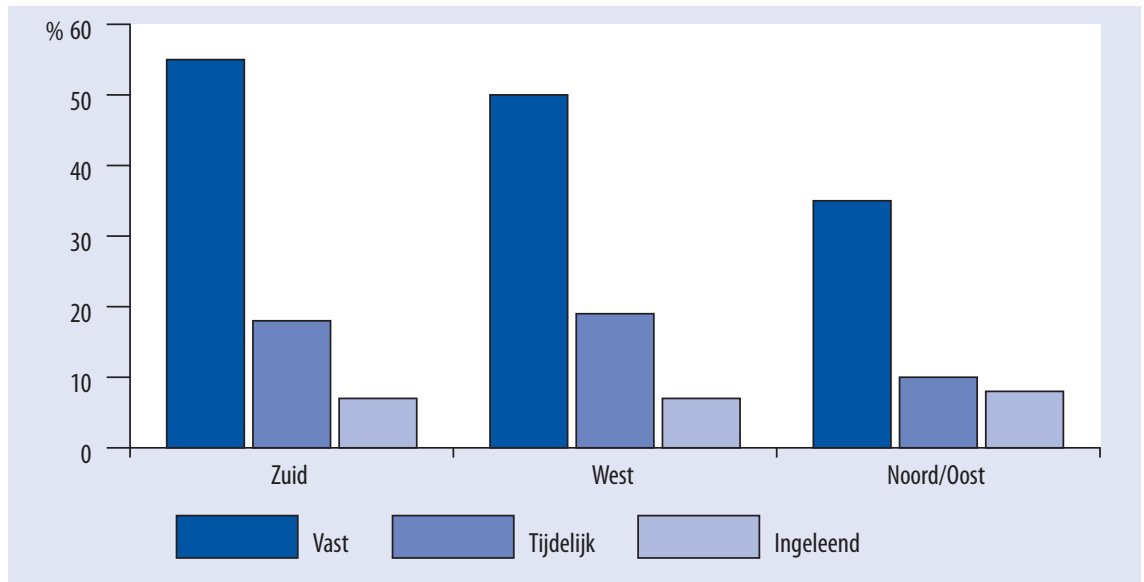

Bron: ROA, Arbeidsmarktmonitor Metalektro, 2012

\section{Verdere daling van opleidingsinvesteringen als percentage van de loonsom}

Misschien wel juist in economisch mindere tijden is het van belang dat bedrijven blijven investeren in het kennisniveau van hun personeel. Aangezien er dan minder productie is kan er soms meer tijd aan training besteed worden. Hier staat echter tegenover dat er tijdens de economische crisis bij veel bedrijven minder geld beschikbaar is. Sinds 2004 is aan het werkgeverspanel gevraagd hoe groot de totale outof-pocket kosten (als percentage van de loonsom) zijn die zij jaarlijks besteden aan cursussen en trainingen voor hun technisch personeel. De intrede van de economische crisis heeft dit percentage flink doen afnemen (Figuur 4.3). Metalektrobedrijven gaven in 2012 gemiddeld nog $1,3 \%$ van de loonsom uit aan directe kosten voor trainingen en cursussen van hun technisch personeel. Dit is iets lager dan in $201 \mathrm{I}$ toen bedrijven gemiddeld I, $5 \%$ van de loonsom aan directe trainingskosten besteedden. Dat de directe kosten als percentage van de loonsom de laatste jaren afnemen kan verschillende oorzaken hebben, maar dat de economische crisis hierbij een belangrijke rol speelt lijkt aannemelijk. Als bedrijven in zwaar weer verkeren zullen zij minder geld aan training spenderen. Wellicht kiezen zij er dan eerder voor om cursussen of trainingen in eigen huis aan te bieden. Zo kunnen de trainingskosten gedrukt worden, terwijl er toch geïnvesteerd wordt in het kennisniveau van de medewerkers.

Verder verschillen de directe trainingskosten als percentage van de loonsom per regio en bedrijfsgrootte. In het Westen vertegenwoordigen deze kosten I, 6\% van de loonsom, in het Zuiden I,3\% en in de regio Noord/Oost slechts o,8\%. Grote bedrijven besteden een groter percentage van de loonsom aan directe trainingskosten dan bedrijven uit het midden- en kleinbedrijf. Voor bedrijven met maximaal so werknemers bedragen 
de trainingskosten I,I\%, voor bedrijven van 5I-250 werknemers I, $3 \%$ en voor bedrijven met meer dan 25I werknemers $2,2 \%$ van de loonsom.

Figuur 4.3

Ontwikkeling gemiddelde totale opleidingskosten per bedrijf als percentage van de loonsom, 2004-2012

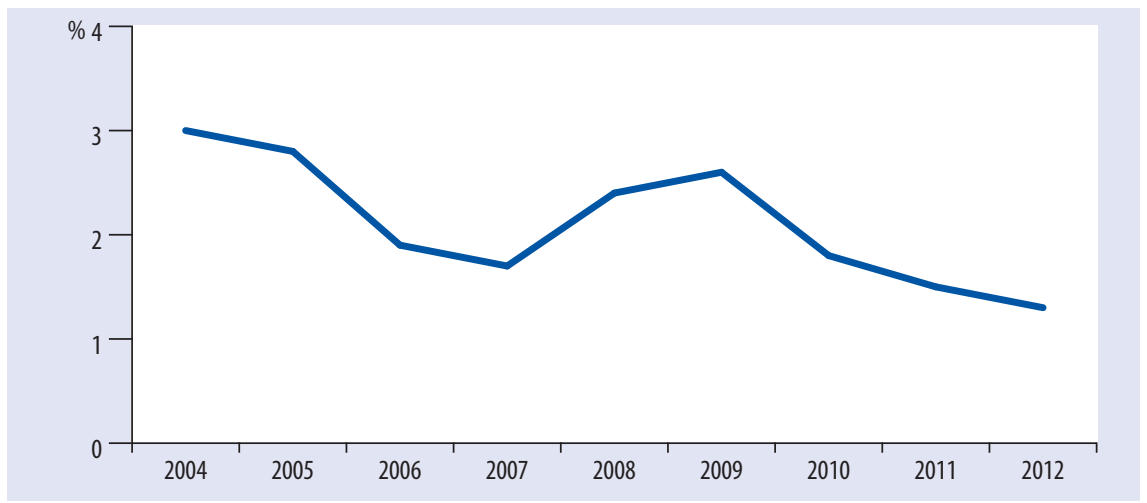

Bron: ROA, Arbeidsmarktmonitor Metalektro, 2004-2012

\section{Trainingen doorgaans gericht op uitoefening van de huidige functie}

In 2012 waren de cursussen en trainingen die door het technisch personeel gevolgd werden net als in 2oII primair gericht op hun huidige functie. Dit was het geval voor $77 \%$ van de gevolgde cursussen. Verder was $21 \%$ van de cursussen en trainingen van het technisch personeel weliswaar niet gericht op de huidige functie, maar op de verdere loopbaan binnen het eigen bedrijf. Deze trainingen zijn erop gericht om werknemers klaar te stomen voor een vervolgstap binnen het bedrijf, maar omdat deze gericht zijn op de iets langere termijn loopt de werkgever meer risico dat de werknemer tussentijds vertrekt. Hierdoor kunnen werkgevers terughoudender zijn om werknemers aan dergelijke cursussen te laten deelnemen. Hier staat tegenover dat bedrijven die juist wel durven te investeren in de opleiding van hun medewerkers voor de langere termijn, interessanter zijn voor (potentiële) medewerkers omdat zij zich bij dergelijke bedrijven beter kunnen ontwikkelen. Zo kunnen bedrijven zich profileren als aantrekkelijke werkgever en zich onderscheiden in de strijd om de schaarse groep technici waaruit de komende jaren geput kan worden.

De trainingsdeelname met het oog op een verdere loopbaan buiten het bedrijf was in 2012 opnieuw minimaal. Bij een gemiddeld bedrijf in de Metalektro was $2 \%$ van alle cursussen waar het technisch personeel aan deelnam gericht op de verdere loopbaan buiten het eigen bedrijf. Hoewel het voor afzonderlijke bedrijven niet interessant mag lijken om als het ware voor andere bedrijven op te leiden, is dit voor de ontwikkeling van de sector als geheel wel van wezenlijk belang. Zeker met het oog op de duurzame 
inzetbaarheid van het technisch personeel, vergroot laatstgenoemde training hun kansen op de externe arbeidsmarkt.

\section{Initiatief tot training veelal top-down of samen met werknemer genomen, zelden vanuit werknemer zelf}

Hoewel vaak gesteld wordt dat de ontwikkeling van het personeel een gedeelde verantwoordelijkheid is tussen zowel werkgever als werknemer is dit nog niet altijd terug te zien aan wie het initiatief neemt wanneer het gaat om trainingen en cursussen voor het technisch personeel (Figuur 4.4). Minder dan de helft van de bedrijven geeft aan dat een gezamenlijk initiatief het meest voorkomt. Bij gemiddeld een derde van de bedrijven is de direct leidinggevende doorgaans de initiator voor trainingsdeelname van het technisch personeel en bij I4\% wordt meestal het initiatief genomen door de HR-afdeling. In slechts 6\% van de bedrijven is de werknemer meestal zelf degene die initiatief toont en een verzoek tot trainingsdeelname indient. Niet bekend is of dit in algemene zin veroorzaakt wordt doordat werknemers zelf niet zo zeer geïnteresseerd zijn in scholing of dat zij terughoudend zijn om hun leidinggevende te vragen of zij een training of cursus mogen volgen, die het bedrijf hen niet aanbiedt.

\section{Figuur 4.4}

Initiatiefnemer(s) cursussen en trainingen voor het technisch personeel, 2012
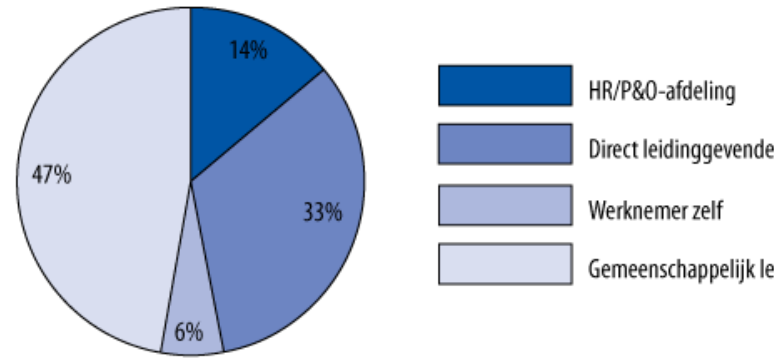

Werknemer zelf

Gemeenschappelijk leidinggevende/ werknemer

Bron: ROA, Arbeidsmarktmonitor Metalektro, 2012

Vergroten betrokkenheid werknemers vooral door functioneringsgesprekken en bevordering coachend leiderschap

Inhakend op het voorgaande, is ook aan werkgevers gevraagd wat er in hun bedrijfsvestiging wordt gedaan om de betrokkenheid van het technisch personeel bij hun eigen opleiding en ontwikkeling te vergroten. Figuur 4.5 zet mogelijke maatregelen op een rij die werkgevers kunnen nemen ter bevordering van de betrokkenheid van het technisch personeel bij hun eigen opleiding en ontwikkeling. In 2012 heeft maar II\% van de bedrijven geen activiteiten ontplooid om de eigen betrokkenheid van het tech- 
nisch personeel op dit vlak te stimuleren. Dit wijst er op dat er consensus bestaat over het feit dat medewerkers medeverantwoordelijk zijn voor hun eigen ontwikkeling. De overgrote meerderheid van de bedrijven heeft in 2012 immers wel actie ondernomen om de eigen betrokkenheid van medewerkers te stimuleren. Hierbij kan het gaan om één activiteit die zij vanuit dit oogpunt hebben toegepast, maar het is evengoed mogelijk dat zij meerdere activiteiten naast elkaar hebben ontplooid om de betrokkenheid van technici bij de eigen ontwikkeling te vergroten.

\section{Figuur 4.5}

Activiteiten ter stimulering van betrokkenheid van technisch personeel bij eigen opleiding en ontwikkeling, 2012

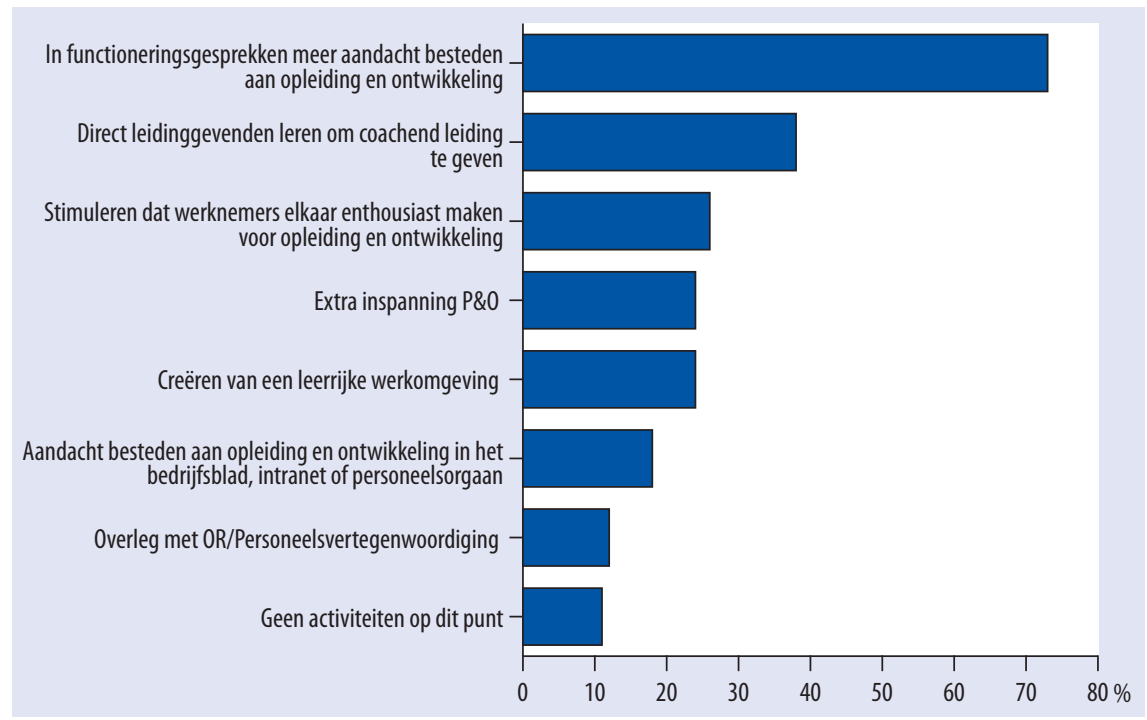

Bron: ROA, Arbeidsmarktmonitor Metalektro, 2012

Noot: Alleen die activiteiten zijn in de figuur opgenomen die door ten minste $10 \%$ van de werkgevers genoemd zijn.

In veel bedrijven lijkt hierbij een cruciale rol weggelegd voor functioneringsgesprekken die kunnen worden aangegrepen om onderwerpen als opleiding en ontwikkeling aan bod te laten komen. Bijna driekwart van de bedrijven trachtte de betrokkenheid van het technisch personeel in 2012 te vergroten door hier tijdens functioneringsgesprekken meer aandacht aan te besteden. Daarmee is dit veruit het vaakst genoemde instrument om de betrokkenheid bij de eigen opleiding en ontwikkeling van het technisch personeel te vergroten. Op behoorlijke afstand volgt een activiteit die is toegespitst op de direct leidinggevenden. Bij bijna vier op de tien bedrijven wordt aan direct leidinggevenden geleerd hoe zij op adequate wijze coachend leiding kunnen geven om een grotere betrokkenheid onder technici te bewerkstelligen. Drie andere activiteiten die door circa een kwart van de bedrijven worden ingezet ter bevordering van de betrokkenheid van het technisch personeel zijn: het stimuleren dat werkne- 
mers elkaar aansporen om actief bezig te zijn met hun eigen opleiding en ontwikkeling, het leveren van extra inspanningen door de $\mathrm{P} \& \mathrm{O}$-afdeling, en het creëren van een leerrijke werkomgeving.

\section{Veruit de meeste trainingen zijn vaktechnisch gericht}

Een ander belangrijk aspect van de opleidingsinspanningen in de Metalektro is het soort trainingen en cursussen dat door het technisch personeel gevolgd wordt. Figuur 4.6 laat zien op welke terreinen het technisch personeel in 2012 één of meerdere cursussen en trainingen heeft gevolgd. Daarnaast wordt de inhoud van de trainingen en cursussen in 2012 vergeleken met 20II. Allereerst valt op dat er in 2012 niet minder aan opleiding en training wordt gedaan, ondanks de dalende out-of-pocket uitgaven aan opleidingen (zie Figuur 4.3).

\section{Figuur 4.6}

Terreinen waarop technisch personeel aan cursus of training heeft deelgenomen, 2011-2012

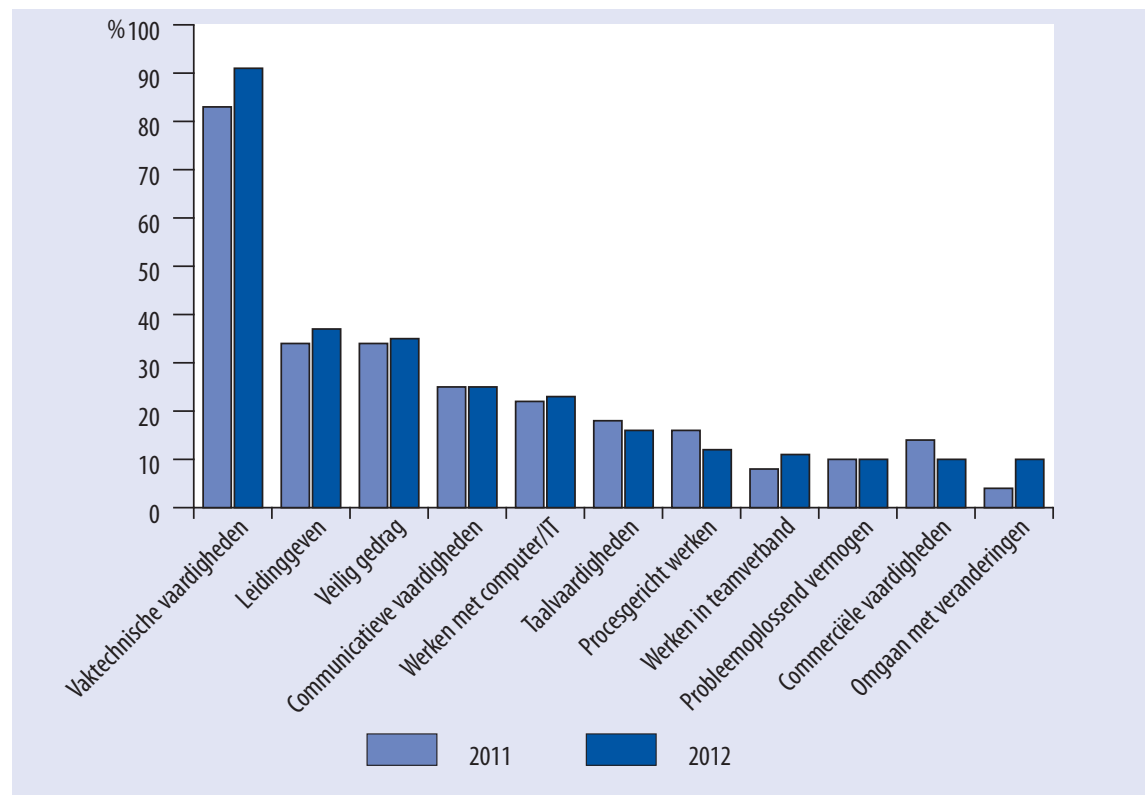

Bron: ROA, Arbeidsmarktmonitor Metalektro, 2011-2012

Noot: Alleen die cursussen die in 2012 door ten minste 10\% van de bedrijven genoemd werden zijn opgenomen in de figuur.

Hoewel verderop in deze rapportage uit Figuur 7.3 blijkt dat bedrijven verwachten dat er in 2013 meer nadruk zal komen te liggen op gedragsmatige competenties, blijkt dit nog niet uit de inhoud van de trainingen die in 2012 gevolgd werden (Figuur 4.6). In 
2012 lag nog altijd veruit de meeste nadruk op vakinhoudelijke trainingen.7 Rekening houdend met de eerdere bevinding dat trainingen in de Metalektro primair gericht zijn op de huidige functie ( $77 \%)$, is het dan weer minder verwonderlijk dat de ontwikkeling van vaktechnische vaardigheden in veel cursussen centraal staat. In meer dan negen van de tien bedrijven werden in 2012 door het technisch personeel trainingen gevolgd die gericht zijn op de ontwikkeling van vaktechnische vaardigheden. Dit is al jaren het meest gangbare type training voor technisch personeel, maar in 2012 is dit percentage verder gestegen. In vergelijking met $201 \mathrm{I}$ is het percentage technici dat een vakspecifieke training volgde met $8 \%$-punt gestegen en daarmee is dit de grootste stijging van alle typen cursussen.

Naast deze vakspecifieke cursussen was er in 2012 ook weer veel aandacht voor soft skills zoals leidinggeven en veilig gedrag. De deelname aan cursussen van deze aard is bovendien enigszins toegenomen ten opzichte van $201 \mathrm{I}$. Bij ruim een derde van de bedrijven heeft het technisch personeel dergelijke cursussen gevolgd. Andere populaire cursussen voor technici hebben betrekking op de ontwikkeling van communicatieve vaardigheden en ICT. Ook valt op dat in 2012 de deelname van technisch personeel aan cursussen gericht op het omgaan met veranderingen behoorlijk is toegenomen.

De hiervoor besproken cursussen waar het technisch personeel aan heeft deelgenomen hadden betrekking op de feitelijke deelname in de jaren 201 en 20I2. Aan de bedrijven is ook gevraagd op welke terreinen zij verwachten dat hun technisch personeel in 2013 cursussen of trainingen zal volgen. Bedrijven verwachtten in 2012 dat de cursusdeelname van het technisch personeel in 2013 op de meeste terreinen licht zal toenemen. Volgens de bedrijven zullen technici in 2013, in vergelijking met 20I2, met name vaker in staat gesteld worden om deel te nemen aan cursussen op het gebied van procesgericht werken (+10\%-punt) en veilig gedrag (+8\%-punt). De grootste daling wordt verwacht voor de deelname aan cursussen gericht op leidinggeven (-8\%-punt).

Vooral dit laatste wekt de aandacht, omdat juist het bevorderen van coachend leiderschap naar plaats drie gestegen is in de rangschikking van de speerpunten van het toekomstig personeelsbeleid (zie Hoofdstuk 7, Figuur 7.4). Bovendien zagen we eerder dat bij bijna vier op de tien bedrijven aan leidinggevenden wordt geleerd hoe zij op adequate wijze coachend leiding kunnen geven om een grotere betrokkenheid bij de eigen opleiding en ontwikkeling van technici te realiseren (Figuur 4.5). Men zou dus verwachten dat dit terug te zien zou zijn in een toename van cursussen gericht op leidinggeven. Een mogelijke verklaring voor deze ogenschijnlijke inconsistentie kan zijn dat het aanleren van coachend leiderschap bij leidinggevenden vaak gerealiseerd wordt door middel van informeel leren op de werkvloer en dus niet door formele

7. Deze schijnbare tegenstelling kan echter ook veroorzaakt worden door de vraagstelling bij de vraag over welke competenties zullen toenemen. Eén antwoordcategorie luidt daar immers 'gedragsmatige competenties worden belangrijker'. Dit betekent derhalve niet per definitie dat gedragsmatige competenties ook de meest belangrijke competenties zijn. 
cursussen. Hiervoor kunnen ervaren leidinggevenden worden ingezet die de minder ervaren leidinggevenden wegwijs maken op dit punt.

\section{Grootste belemmeringen bij opleiden zijn tijd en geld, maar er zijn ook veel bedrijven zonder belemmeringen}

Om de ontwikkeling van kennis en vaardigheden in de Metalektro te kunnen vergroten, is het een eerste vereiste om in kaart te brengen waar er in de praktijk belemmeringen worden ervaren. Pas wanneer bedrijven deze 'bottlenecks' concreet inzichtelijk hebben gemaakt, kunnen zij hier actie op ondernemen. Zo is het een feit dat cursussen soms veel geld kosten, maar bedrijven die cursussen te duur vinden kunnen wel naar andere mogelijkheden zoeken om de kennis en vaardigheden van hun personeel op peil te houden. Voor deze bedrijven zou het wellicht nuttig zijn om meer aandacht te besteden aan informele kennisoverdracht tussen medewerkers binnen de organisatie.

Figuur 4.7 geeft weer welke belemmerende factoren in 2012 door bedrijven ervaren werden bij de scholing van (een deel van) het technisch personeel. Een derde van de bedrijven ervaart in de praktijk geen belemmeringen bij de scholing van technici. Dit is vergelijkbaar met 20 II $(35 \%)$, maar beduidend meer dan in 2010 toen slechts een kwart van de bedrijven (26\%) geen belemmeringen zag. Gedurende de afgelopen vijf jaar wordt het tijdsaspect dat gepaard gaat met de deelname aan cursussen telkens het vaakst als struikelblok genoemd. Wanneer medewerkers onder werktijd een cursus volgen, betekent dit eenvoudigweg dat zij gedurende die periode niet productief inzetbaar zijn. In 2012 zien vier op de tien bedrijven het feit dat cursussen veel tijd kosten als belemmerende factor die de cursusdeelname van technici in de weg staat. Daarbij is de laatste jaren bovendien een stijgende trend zichtbaar in het percentage bedrijven dat het tijdsaspect als belemmering ziet.

Verder vinden veel bedrijven (28\%) dat cursussen dermate veel geld kosten dat zij de trainingsdeelname in de weg kunnen staan. Opvallend daarbij is dat grote bedrijven deze reden twee keer zo vaak noemen als bedrijven uit het midden- en kleinbedrijf. Grote bedrijven geven absoluut gezien weliswaar grotere bedragen uit aan training omdat er meer werknemers getraind worden. Daarom is het opvallend dat grote bedrijven toch beduidend vaker de cursuskosten als belemmerende factor noemen. Het percentage bedrijven dat hoge trainingskosten als belemmering ziet is vergelijkbaar met 20II, maar aanzienlijk hoger dan in 20 IO toen $17 \%$ de cursuskosten als belemmering aanwees.

Op de derde plek volgt de belemmering dat cursussen niet beschikbaar zijn in de regio waar de bedrijfsvestiging gelegen is. Hoewel de moeite die het kost om deel te nemen aan een cursus als investering gezien kan worden, wordt dit in sommige gevallen toch als belemmerende factor aangeduid. In 2012 werd dit door $17 \%$ van de bedrijven als 
belemmering gezien, tegenover slechts IO\% van de bedrijven in 2010 , maar $20 \%$ van de bedrijven in $201 \mathrm{I}$.

\section{Figuur 4.7}

Belemmerende factoren bij de scholing van het technisch personeel, 2012

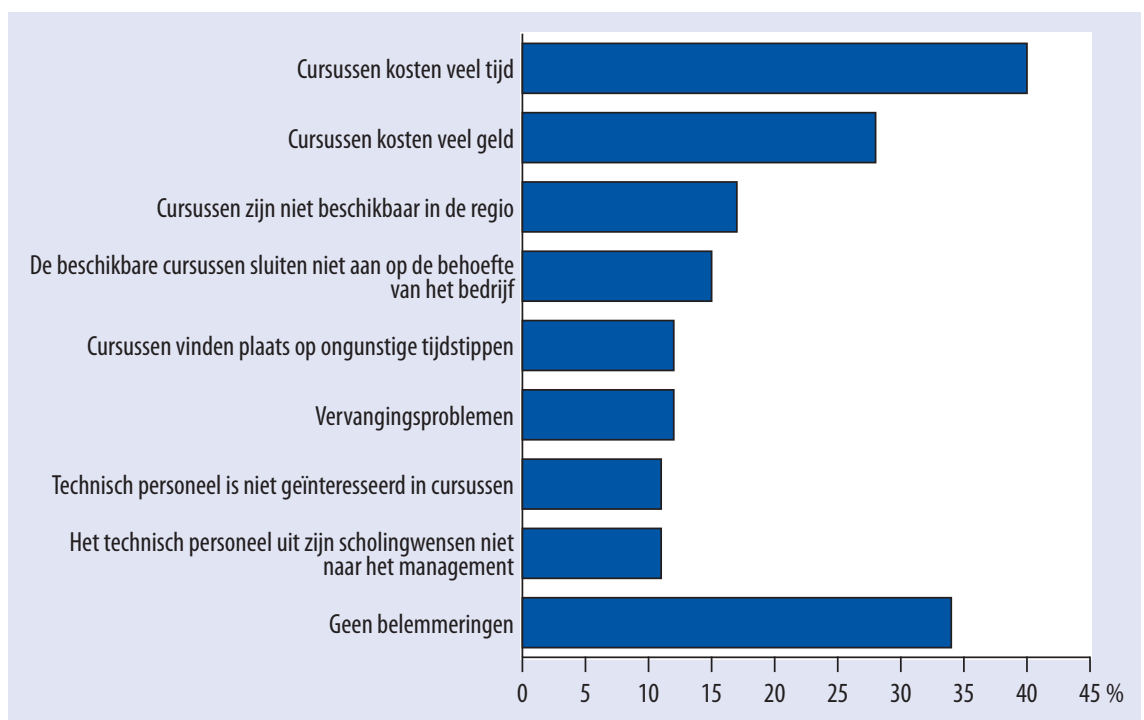

Bron: ROA, Arbeidsmarktmonitor Metalektro, 2012

\subsection{Niveau interne mobiliteit ongewijzigd in 2012}

De deelname van technisch personeel aan formele trainingen en cursussen is niet de enige manier om kennis en vaardigheden op peil te houden of verder te ontwikkelen. Veruit het grootste deel van de totale tijd die werknemers op hun werk aan leren besteden heeft betrekking op informeel leren. ${ }^{8}$ Door het technisch personeel mogelijkheden te bieden om intern door te stromen kan een werkgever faciliteren dat medewerkers meer tijd besteden aan taken waarvan zij leren. Loopbaanmogelijkheden binnen het bedrijf houden het werk uitdagend omdat het personeel zo in staat wordt gesteld om zich te blijven ontwikkelen. Hierbij kan zowel sprake zijn van horizontale doorstroom naar een baan op een vergelijkbaar functieniveau als van verticale doorstroom. Bij verticale doorstroom gaat het in de meeste gevallen om promotie naar een hogere functie, maar kan er ook sprake zijn van demotie waarbij medewerkers een andere functie op een lager niveau accepteren. In algemene zin kan interne mobiliteit er toe bijdragen dat medewerkers gemotiveerd blijven doordat zij competenties en

8. Borghans, L., Fouarge, D. \& de Grip, A. (20II), Een leven lang leren in Nederland, ROA-R-20II/5. 
vaardigheden kunnen ontwikkelen die hun loopbaanperspectief en duurzame inzetbaarheid verbeteren.

In nagenoeg de helft van de bedrijven was er in 2012 sprake van interne mobiliteit van technisch personeel. Dit is vergelijkbaar met het niveau in 20II, maar lager dan enkele jaren eerder. Zo was er in 2008 bijvoorbeeld nog bij 62\% van de bedrijven interne mobiliteit van technisch personeel. Bij de bedrijven waar in 2012 technisch personeel doorstroomde naar andere functies ging het hierbij gemiddeld om $5 \%$ van het totaal aantal werkzame technici binnen het bedrijf. Deze doorstroom van technisch personeel had in de meeste gevallen betrekking op doorstroom naar een andere technische functie. Wanneer de interne mobiliteit van technisch personeel wordt gedifferentieerd naar het niveau van de nieuwe functie, dan blijkt dat de helft ( $51 \%)$ van de technici die in 2012 intern doorstroomden promotie gemaakt heeft en $43 \%$ in een nieuwe functie op een vergelijkbaar niveau is gaan werken. De overige $7 \%$ van de interne mobiliteit van technici heeft betrekking op demotie.

\subsection{HR-instrumenten: Toename gebruik van diverse gespreksvormen ('soft'), minder gebruik van meer 'concrete' instrumenten}

In paragraaf 4.3 komen de HR-instrumenten aan bod die metalektrobedrijven inzetten bij het loopbaanmanagement van het technisch personeel. Onderstaande HR-instrumenten kunnen worden onderverdeeld in vier bredere categorieën:

a) de bepaling van het huidige competentieniveau van het technisch personeel (assessment);

b) het vastleggen van doelen en acties;

c) het volgen van scholing;

d) het opdoen van de gewenste werkervaring.

In Figuur 4.8 worden deze verschillende componenten van de loopbaanmanagementcyclus weergegeven, met daarbij de specifieke HR-instrumenten die bedrijven inzetten voor hun technisch personeel. Naast deze instrumenten, die bij een specifiek onderdeel van het loopbaanmanagement behoren, worden in de figuur nog twee algemene instrumenten weergegeven: loopbaanplanning en werkoverleg. Deze zijn breder toepasbaar en kunnen ter ondersteuning van alle vier de categorieën HR instrumenten ingezet worden. Figuur 4.8 geeft niet alleen de resultaten weer voor 20I2, maar ook die van 2010 en 20II. Dit om de cijfers voor 2012 beter te kunnen duiden en mogelijke trends te kunnen ontdekken. Hierna worden de resultaten per categorie toegelicht.

Zoals eerder aangegeven kunnen de HR-instrumenten 'loopbaanplanning' en 'werkoverleg' doorlopend worden ingezet bij het loopbaanmanagement voor het technisch personeel. In 2012 werd werkoverleg vooral veelvuldig ingezet ten behoeve van het loopbaanmanagement van technici. Dit was het geval in bijna negen op de tien bedrijven. Bovendien blijkt dat werkoverleg hiervoor in toenemende mate wordt ingezet, want 
in 2010 maakten zeven op de tien bedrijven gebruik van dit HR-instrument. Aan loopbaanplanning wordt in beduidend minder bedrijven gedaan en dit percentage neemt de laatste jaren bovendien af.

\section{Figuur 4.8}

HR-instrumenten die worden ingezet voor de meerderheid van het technisch personeel, 2010-2012

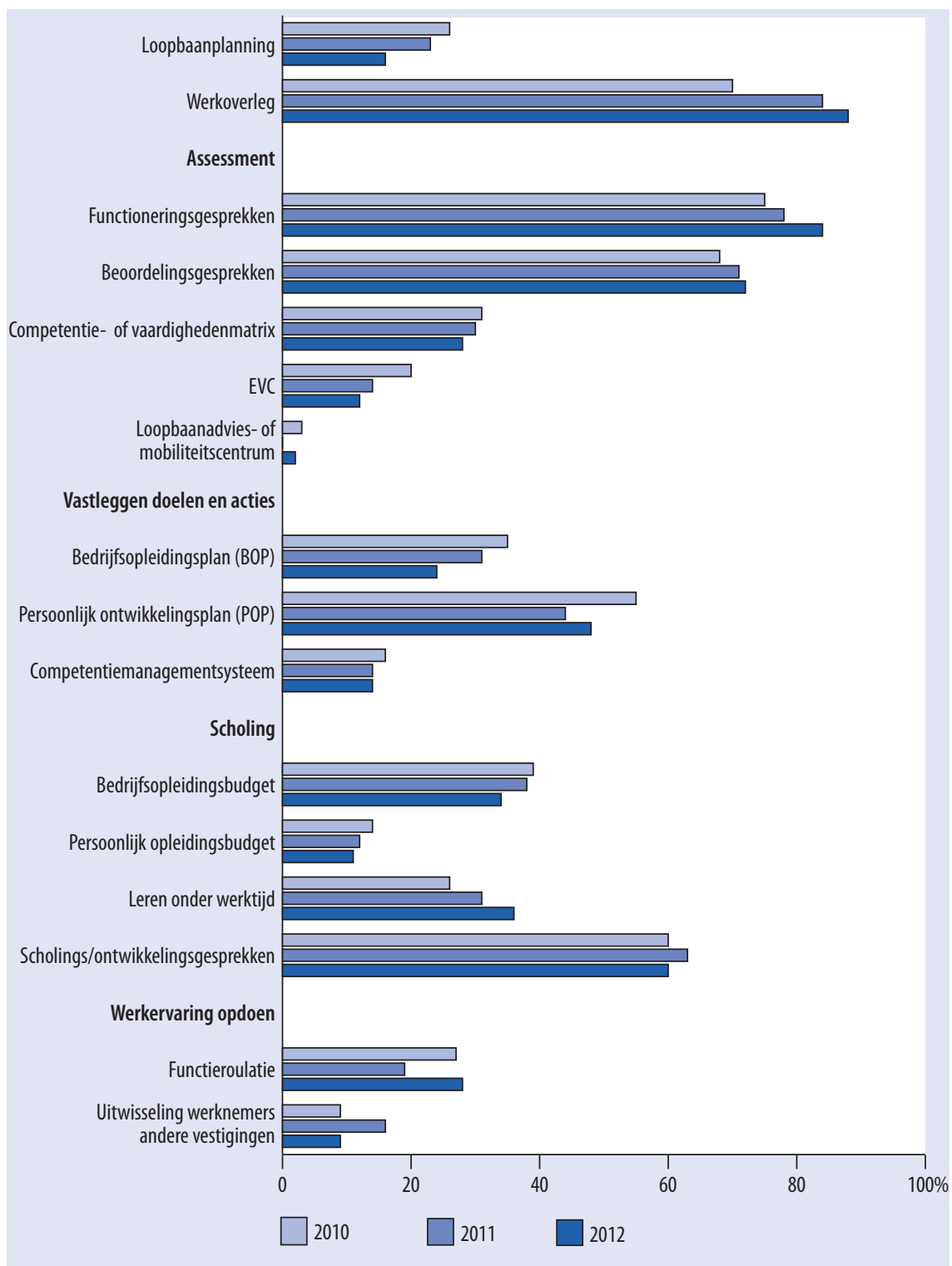

Bron: ROA, Arbeidsmarktmonitor Metalektro, 2010-2012 
Voor het vaststellen van het huidige competentieniveau van het technisch personeel (a) blijkt er sprake te zijn van een kentering bij het gebruik van de hiervoor ingezette HR-instrumenten. Relatief 'softe' gespreksvormen zoals functionerings- en beoordelingsgesprekken worden steeds vaker ingezet. Daarentegen lijken de concretere instrumenten zoals erkenning van verworven competenties (EVC) en het gebruik van competentie- of vaardighedenmatrices de voorbije jaren enigszins op hun retour te zijn.

Het vaststellen van doelen en acties (b) draagt er tijdens het loopbaanmanagement toe bij dat er achteraf geen misverstanden kunnen bestaan over de tussen werkgever en werknemer gemaakte afspraken. Bijna de helft van de bedrijven makkte in 2012 bij een meerderheid van het technisch personeel gebruik van een persoonlijk ontwikkelingsplan (POP). Uit de figuur blijkt verder dat de populariteit van het bedrijfsopleidingsplan (BOP) de laatste jaren afneemt.

Bij het faciliteren van de scholingsdeelname van het technisch personeel (c) maken bedrijven, evenals voorgaande jaren, het vaakst gebruik van scholings- of ontwikkelingsgesprekken. In 60\% van de bedrijven werden dergelijken gesprekken in 2012 gevoerd. Verder blijkt uit de figuur dat leren onder werktijd tussen 2010 en 2012 gestaag toegenomen is. Mogelijk investeren bedrijven die te kampen hebben met teruglopende productie in hun technisch personeel, zodat deze optimaal benut kunnen worden zodra de productie weer toeneemt. Ook kan het er op wijzen dat de upgrading van het werk in de Metalektro bijdraagt aan een leerrijk werkklimaat. Volgens de metalektrobedrijven wordt er de laatste jaren juist steeds minder gebruik gemakt van (formele) persoonlijke opleidingsbudgetten alsook bedrijfsopleidingsbudgetten.

De ontwikkeling van het technisch personeel kan tevens een flinke boost krijgen door hen relevante werkervaring op te laten doen (d). Hierbij spelen er twee tegengestelde ontwikkelingen. Allereerst bereikte het niveau van de functieroulatie van het technisch personeel in 20I2, na een dip in 20II, opnieuw het niveau van 20IO. In 2012 werd er bij bijna $30 \%$ van de bedrijven gebruik gemaakt van functieroulatie bij de technische functies. De uitwisseling van medewerkers met andere bedrijfsvestigingen bewandelde juist de omgekeerde weg. $\mathrm{Na}$ een vrij forse toename in $201 \mathrm{I}$ nam dit in 2012 weer af tot het lagere niveau van 2010.

\section{Tekstbox 4.1 Bij Siemens wordt job-rotation bij de aanstelling al verankerd}

Ook binnen Siemens is job-rotation een belangrijke HR pijler. Wouter Vlasblom - HR directeur van Siemens Nederland - geeft aan dat de doelstelling binnen Siemens is dat jaarlijks 10 procent van de medewerkers van baan of functie verandert. Dit wordt in de brede zin van het woord bedoeld, dus ook ontwikkeling binnen een functie of een promotie kan hiertoe gerekend worden. Hoe belangrijk dit is, komt al tot uiting zodra een nieuwe medewerker het bedrijf binnenkomt. Deze moet een job-rotation clausule ondertekenen bij zijn aanstellingsgesprek. Dit zorgt ervoor dat het werk uitdagend, en de medewerker flexibel blijft en dat iemand niet vastroest. 


\section{Technologische innovaties en organisatorische veranderingen}

In 2012 heeft $85 \%$ van alle metalektrobedrijven éen of meerdere technologische innovaties doorgevoerd. Hoewel dit een behoorlijk percentage is, verwachtten bedrijven in 2011 eigenlijk nog meer te innoveren op technologisch gebied. Hetzelfde geldt voor organisatorische vernieuwingen. Ook hier blijft het percentage bedrijven dat vernieuwd heeft in 2012 achter bij de verwachtingen. Desondanks heeft meer dan 30\% van de bedrijven er in 2012 voor gezorgd dat hun eigen technisch personeel variabeler inzetbaar is. Ook voor de komende jaren lijkt dit een populaire organisatorische vernieuwing. Bedrijven hebben met deze verandering als doel dat de productie flexibeler wordt.

In vergelijking met $20 I I$ is de behoefte aan breed inzetbaar technisch uitvoerend personeel toegenomen. Dit heeft met name te maken met schommelingen in de vraag en met vervanging tijdens afwezigheid. Ondanks deze toename in de behoefte, is ongeveer $65 \%$ van de bedrijven tevreden met de mate waarin hun personeel breed inzetbaar is. Met betrekking tot uitbestedingen is in 2012 een afname waargenomen. Bedrijven verwachten ook voor de komende jaren een daling in de uitbesteding van taken aan zowel bedrijven binnen als buiten Nederland. 


\subsection{Technologische innovaties voornamelijk gericht op verbeteringen bestaande producten en processen en nieuwe producten}

De eerste vorm van innovatie die in dit hoofdstuk besproken wordt is technologische innovatie. Technologische innovatie kan betrekking hebben op producten of processen. Beide vormen van innovatie zijn in de Metalektro belangrijk voor de concurrentiepositie van bedrijven. We gaan eerst even terug in de tijd. In 201 w werd over het algemeen iets meer geïnnoveerd op technologisch gebied dan in 20I0. $82 \%$ van de bedrijven gaf in $201 \mathrm{I}$ aan technologische innovaties te hebben doorgevoerd. Het gaat dan om productinnovaties ofwel procesinnovaties. In 2 oII verwachtte $94 \%$ van de bedrijven in het daaropvolgende jaar één of meerdere technologische innovaties door te voeren. In Figuur 5.I zien we de gerealiseerde technologische innovaties in 20I2. Bovendien tonen we op basis van de meting van $201 \mathrm{I}$ de toen voor 2012 verwachtte technologische innovaties.

\section{Figuur 5.1}

Gerealiseerde en verwachte technologische innovaties met betrekking tot 2012 (\% bedrijven)

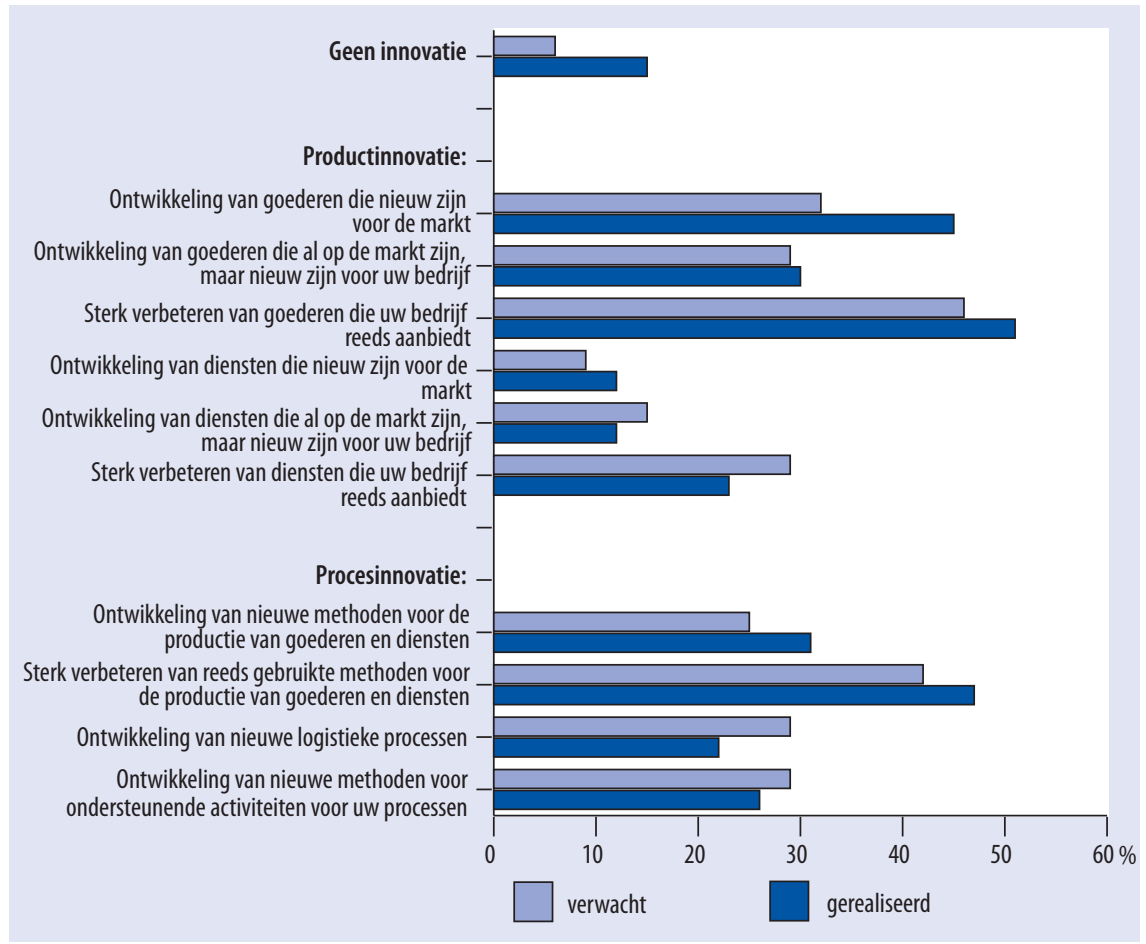

Bron: ROA, Arbeidsmarktmonitor Metalektro, 2011-2012

De donkerblauwe balken geven de gerealiseerde technologische innovaties in 2012 aan. $85 \%$ van alle bedrijven heeft minstens één technologische innovatie doorgevoerd. Het 
betreft hier - net als vorig jaar - vooral het verbeteren van reeds bestaande producten ( $51 \%)$, het verbeteren van reeds gebruikte methoden voor de productie $(47 \%)$ en het ontwikkelen van nieuwe producten (45\%). De focus van bedrijven lijkt hiermee zowel te liggen op consolidatie, het 'nog beter maken en doen van wat men al doet' alsmede op uitbreiding, met producten die nieuw zijn voor de markt.

De lichtblauwe balken geven de verwachtingen met betrekking tot technologische innovaties voor 2012 aan. Bedrijven hebben deze verwachtingen weergegeven in antwoord op de vragenlijsten van de Arbeidsmarktmonitor Metalektro 20 II. Opvallend is dat in $201 \mathrm{I} 6 \%$ van de metalektrobedrijven voorspelden niet te innoveren in 20I2. Uiteindelijk blijkt dat $16 \%$ van de bedrijven in 2012 niet heeft geïnnoveerd. Voor productinnovatie geldt echter dat bedrijven over het algemeen vaker een innovatie hebben doorgevoerd dan zij in 201 mog voorspelden. Slechts twee van de in Figuur 5.I opgenomen productinnovaties zijn in 2012 minder vaak doorgevoerd dan van tevoren werd verwacht. Het betreft hier het sterk verbeteren van diensten die het bedrijf reeds aanbiedt en de ontwikkeling van diensten die al op de markt zijn, maar nieuw zijn voor het bedrijf. Alle andere vormen van productinnovaties zijn in 2012 vaker doorgevoerd dan in $201 \mathrm{I}$ verwacht werd. Ook bij procesinnovaties zijn er twee innovaties die beduidend vaker zijn doorgevoerd dan werd verwacht. Het betreft hier innovaties die betrekking hebben op de productiemethoden. De innovaties die zich richten op processen zijn minder vaak doorgevoerd dan werd voorspeld.

Zoals we in Figuur 5.I zagen, verschillen de verwachte en gerealiseerde innovaties over het jaar 2012 nogal eens. Terwijl in $201194 \%$ van de bedrijven verwachtte in 2012 minstens één technologische innovatie door te voeren, bleek er in 2012 maar door $85 \%$ van de bedrijven te zijn geïnnoveerd. In deze paragraaf gaan we op bedrijfsniveau kijken of er binnen een en hetzelfde bedrijf inderdaad een discrepantie is tussen verwachte en gerealiseerde technologische innovaties. Dit wordt gedaan op basis van paneldata. Er blijken II2 bedrijven meegedaan te hebben aan zowel de meting in 20 II als aan de meting in 2012.9 Van deze II2 bedrijven, hebben Ioo bedrijven zowel de vragen over verwachte technologische innovaties in 2012 als de vragen over de gerealiseerde innovaties in 2012 beantwoord.

Tabel 5.1

Verwachte en gerealiseerde innovaties met betrekking tot 2012 (\%)

\begin{tabular}{|c|c|c|c|}
\hline \multicolumn{4}{|c|}{ Gerealiseerde technologische innovaties in 2012} \\
\hline \multirow{3}{*}{$\begin{array}{l}\text { Verwachte technologische } \\
\text { innovaties voor } 2012\end{array}$} & & Ja & Nee \\
\hline & Ja & 73 & 13 \\
\hline & Nee & 10 & 4 \\
\hline
\end{tabular}

9. Het betreft hier meting I van $201 \mathrm{I}$ en meting 3 van 20I2. In deze metingen zijn vragen opgenomen over technologische ontwikkelingen met betrekking tot 2012 . 
In Tabel 5.I is een overzicht opgenomen van de bedrijven waarover de verwachte en gerealiseerde technologische innovaties bekend zijn. $73 \%$ van de bedrijven gaf in 20 II aan een technologische innovatie te willen doen in 20I2, én hebben dit ook daadwerkelijk gedaan. $4 \%$ was niet van plan te innoveren en heeft dit ook niet gedaan. De andere $23 \%(10 \%+13 \%)$ heeft in 2012 anders gehandeld dan ze eerder verwachtten. IO\% van de bedrijven verwachtte in 20 II niet te gaan innoveren in 20I2, maar heeft dit toch gedaan. Daar staat tegenover dat $13 \%$ van de bedrijven verwachtte te gaan innoveren maar dit in 2012 uiteindelijk toch niet heeft gedaan.

Door middel van multivariate analyse hebben we geanalyseerd wat voor soort bedrijven een discrepantie hebben tussen hun verwachte en gerealiseerde innovaties met betrekking tot 20I2. Het blijkt dat bedrijven die in $201 \mathrm{I}$ vacatures voor technisch personeel hadden openstaan, minder vaak een verkeerde inschatting hadden van hun technologische innovaties in 2012 dan bedrijven die in $201 \mathrm{I}$ geen vacatures hadden. Ook de regio waarin een bedrijf opereert blijkt gerelateerd te zijn aan de discrepantie tussen verwachte en gerealiseerde technologische innovaties: bedrijven in het westen van het land hebben vaker een discrepantie tussen verwachte en gerealiseerde innovaties dan bedrijven in het Zuiden. De grootte van het bedrijf bleek echter geen rol te spelen in het verklaren van de discrepantie tussen verwachtingen en realisatie.

\subsection{Organisatorische innovaties}

Naast technologische innovaties zijn ook organisatorische vernieuwingen relevant voor het behoud van de concurrentiepositie van bedrijven ${ }^{\text {Io }}$. Het voornaamste doel van organisatorische vernieuwingen is het verbeteren van de bedrijfsprestaties en het ontplooien van de talenten van medewerkers. Het betreft vooral veranderingen op het gebied van organisatie en management, het menselijk kapitaal van het bedrijf en nieuwe vormen van samenwerking in de bedrijfsomgeving. We gaan nu achtereenvolgens in op dit soort veranderingen zoals die hebben plaatsgevonden in 2012 in de Metalektro.

\section{Organisatie en management in 2012: Focus op variabele inzet van het eigen technisch personeel}

Veranderingen die betrekking hebben op de manier waarop het werk wordt georganiseerd, wie waarvoor verantwoordelijk is en hoe het bedrijf door het management geleid wordt, omvatten de eerste vorm van organisatorische innovaties.

In de eerste jaren van de crisis 2008 en 2009 werden er beduidend meer organisatorische veranderingen doorgevoerd, voornamelijk wat betreft organisatie en management. De

Io. Uit het Jaarrapport over 20 II bleek dat technologische en organisatorische vernieuwingen vaak hand in hand gaan. Bedrijven met organisatorische vernieuwingen hebben technologische innovaties en deze zijn bovendien meer vernieuwend. Zie Arbeidsmarktmonitor Metalelektro 2OII (ROA-R-20I2/I). 
afname van de hoeveelheid werk maakte het voor bedrijven mogelijk om aanpassingen in de werking en structuur van het bedrijf door te voeren. Na deze piekjaren wat betreft organisatorische vernieuwingen, was het niet verrassend dat in $201 \mathrm{I}$ het aantal veranderingen op het gebied van organisatie en management een stuk lager uitviel. Het percentage bedrijven dat bijvoorbeeld aangaf het aantal managementlagen te hebben teruggebracht, halveerde. Voor 2012 voorspelden de bedrijven echter weer meer vernieuwingen op het gebied van organisatie en management. Slechts 30\% van de bedrijven gaf in $201 \mathrm{I}$ aan dat zij in 2012 helemaal geen organisatorische vernieuwing verwachtten. Een grote meerderheid van $70 \%$ verwachtte dus in 2012 iets aan organisatorische vernieuwing te doen. Het betrof hier hoofdzakelijk het bevorderen van het werken in teamverband en het variabel inzetten van het eigen technisch personeel.

In Figuur 5.2 kunnen we zien of bedrijven in 2012 inderdaad hebben besloten tot meer veranderingen in de organisatie en het management van het bedrijf dan in 20II. Dit blijkt niet het geval te zijn. In plaats van de voorspelde grote meerderheid van $70 \%$ van de bedrijven, heeft een kleine meerderheid van $58 \%$ daadwerkelijk vernieuwd op het gebied van organisatie en management. Dit is te zien aan de $42 \%$ bedrijven die aangeven 'géén verandering' te hebben doorgevoerd. De meeste organisatorische innovaties hadden betrekking op het variabel inzetten van het eigen technisch personeel $(34 \%)$. In vergelijking tot 20 II is deze vernieuwing vaker toegepast. Toen innoveerde maar $22 \%$ van de bedrijven op dit terrein. Drie andere vernieuwingen die in 2012 door meer dan IO\% van de bedrijven zijn doorgevoerd waren: projectmatig werken $(\mathrm{I} 7 \%)$, werken in teams (I4\%) en externe samenwerking (I $\%$ ). Hoewel er over het algemeen regionale verschillen zijn in het doorvoeren van organisatorische veranderingen, is het opvallend dat in het Westen beduidend vaker taakintegratie over afdelingen is doorgevoerd dan in de andere regio's.

\section{Figuur 5.2}

Organisatorische innovaties geïmplementeerd (\% bedrijven), 2012

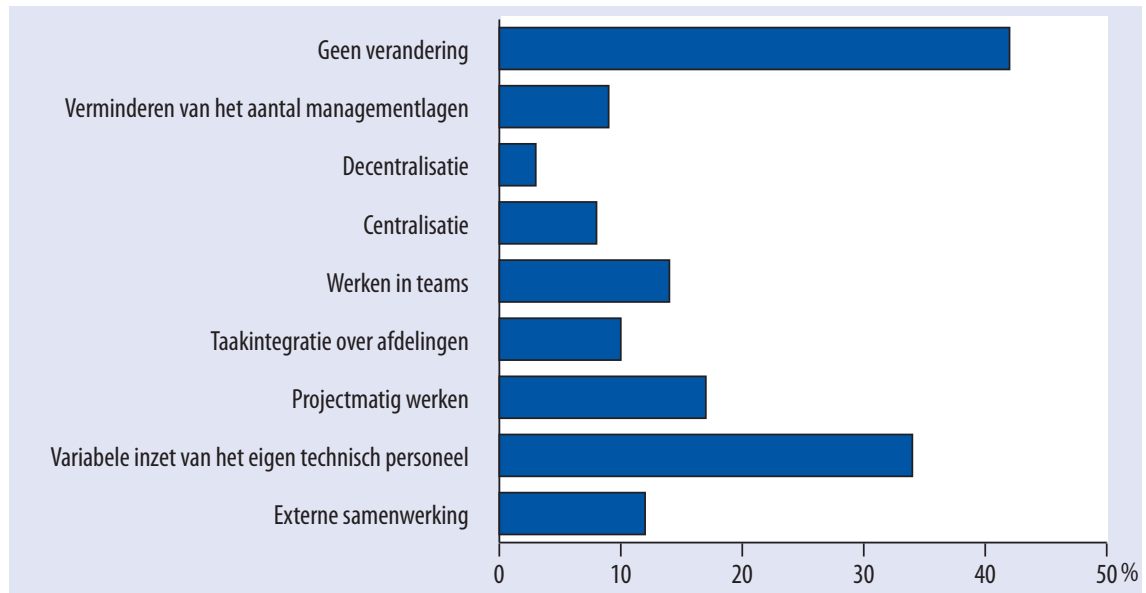

Bron: ROA, Arbeidsmarktmonitor Metalektro, 2012 
In Figuur 5.3 wordt het percentage bedrijven dat een organisatorische verandering heeft geïmplementeerd voor kleine, middelgrote en grote bedrijven weergegeven. Hieruit maken we op dat kleine bedrijven (o-50 medewerkers) over het algemeen vaker geen enkele organisatorische vernieuwing hebben geïmplementeerd dan grotere bedrijven. De helft van de kleine bedrijven heeft in 2012 geen organisatorische veranderingen doorgevoerd. De kleine bedrijven die wel een organisatorische verandering hebben doorgevoerd hebben vooral besloten hun eigen technisch personeel variabel in te zetten. Middelgrote en grote bedrijven hebben vrijwel hetzelfde vernieuwingspercentage: ongeveer $35 \%$ van de middelgrote en grote bedrijven heeft in 2012 geen organisatorische verandering doorgevoerd. Er blijkt wel een verschil in het type innovatie tussen middelgrote en grote bedrijven: het variabel inzetten van eigen technisch personeel is door meer dan $40 \%$ van de middelgrote bedrijven doorgevoerd. Dit is nog geen $30 \%$ voor de grote bedrijven. Grote bedrijven hebben daarentegen vaker een verandering doorgevoerd in de externe samenwerking en hebben vaker activiteiten gecentraliseerd dan middelgrote bedrijven.

\section{Figuur 5.3}

Organisatorische innovaties geïmplementeerd naar bedrijfsgrootte (\% bedrijven), 2012

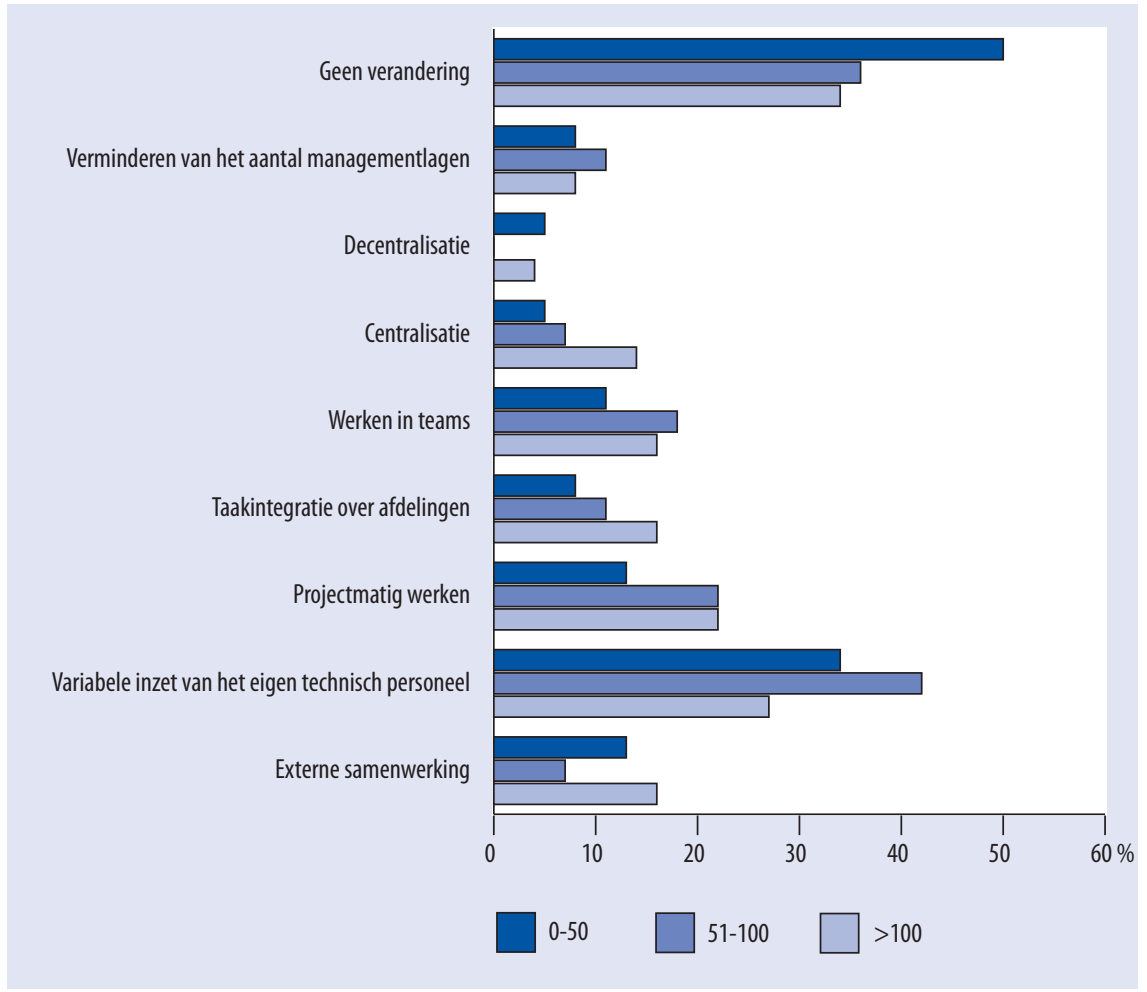

Bron: ROA, Arbeidsmarktmonitor Metalektro, 2012 
De veranderingen die zijn geïmplementeerd, blijken over het algemeen volgens plan te zijn verlopen. De uitzondering hierop vormt de takintegratie over afdelingen. Dit is te zien in Figuur 5.4. Minder dan de helft van de bedrijven die takintegratie over afdelingen heeft ingevoerd geeft aan dat de verandering volgens plan is verlopen. Voor alle andere organisatorische vernieuwingen geldt dat minstens de helft van de bedrijven die de desbetreffende vernieuwing hebben doorgevoerd aangeeft dat dit volgens plan is verlopen. Het verminderen van het aantal managementlagen (94\%) en het decentraliseren (IO०\%) of centraliseren (77\%) van de activiteiten lopen het vaakst volgens plan.

\section{Figuur 5.4}

Evaluatie van geïmplementeerde organisatorische innovaties (\% bedrijven die de desbetreffende innovaties volgens plan hebben doorgevoerd), 2012

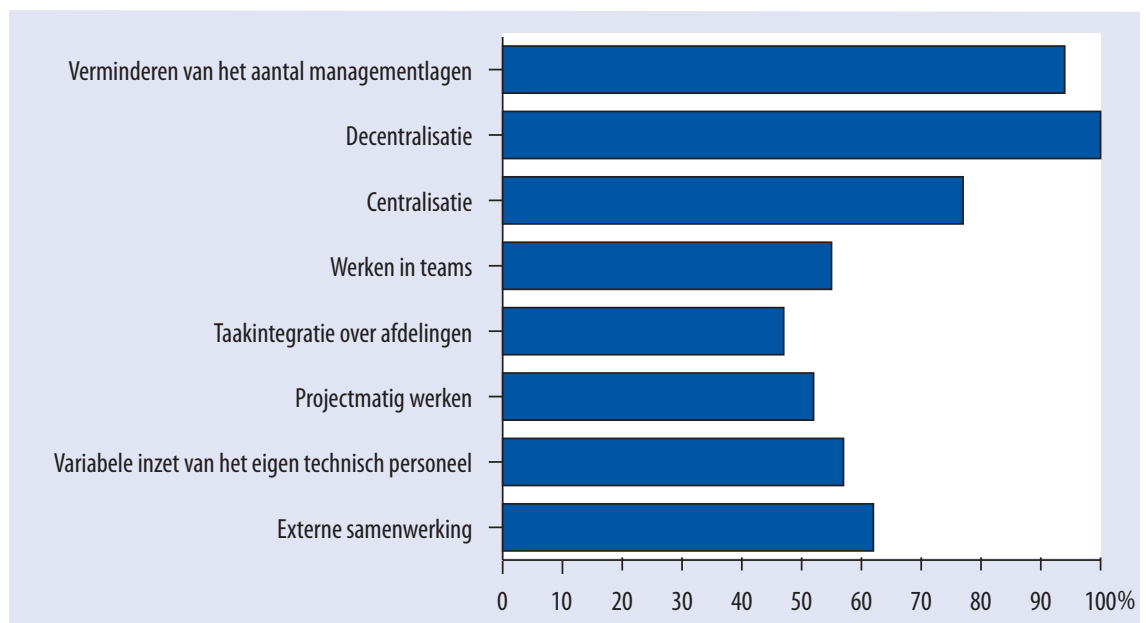

Bron: ROA, Arbeidsmarktmonitor Metalektro, 2012

\section{Organisatie en management in de toekomst: Focus blijft op variabele inzet eigen technisch personeel}

In Figuur 5.5 zien we de geplande organisatorische innovaties voor de komende vijf jaar. Uit de figuur komt naar voren dat het percentage bedrijven dat het eigen technisch personeel variabel wil gaan inzetten nog verder stijgt. Al in 2013 wil $38 \%$ van de bedrijven deze organisatorische innovatie invoeren. Dit in tegenstelling tot het verminderen van het aantal managementlagen, dat de komende jaren verder in populariteit lijkt af te nemen. Deze afname in populariteit is waarschijnlijk het gevolg van de beperkte mogelijkheid die bedrijven nog hebben om de managementlagen verder te verminderen. Waarschijnlijk is het aantal managementlagen de afgelopen jaren al tot een minimum gedaald. Terwijl in $20129 \%$ van de bedrijven het aantal managementlagen heeft teruggebracht (zie Figuur 5.2), verwacht slechts 6\% dit in 2013 te doen. In de jaren 20I4-20I7 neemt dit percentage nog verder af tot $4 \%$ van de 
bedrijven. Ook het invoeren van teamwerk lijkt in alle bedrijven waarvoor dit relevant is al te zijn geïmplementeerd. In de periode 20I4-20I7 verwacht slechts 5\% van de bedrijven tot meer teamwerk te komen. In 2012 heeft nog I4\% deze vorm van werken ingevoerd (zie Figuur 5.2).

Figuur 5.5

Geplande organisatorische innovaties voor de komende vijf jaar (\% bedrijven)

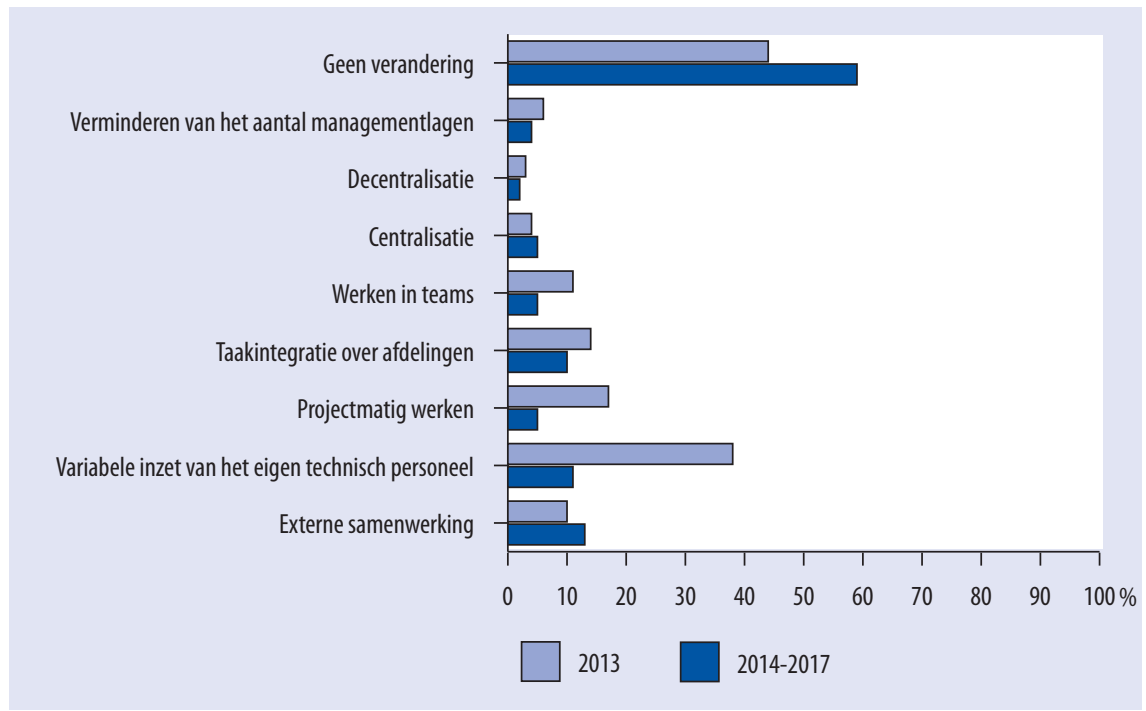

Bron: ROA, Arbeidsmarktmonitor Metalektro, 2012

In Figuur 5.6 wordt een overzicht gegeven van de hoofddoelen van de vier organisatorische innovaties die bedrijven het meest aangeven te implementeren in 20I3. Het betreft de variabele inzet van het eigen technisch personeel, projectmatig werken, taakintegratie over de afdelingen en het werken in teams. Opvallend is dat de hoofddoelen van deze voorgenomen vernieuwingen sterk uiteenlopen. De meeste bedrijven die aangeven in 2013 hun eigen technisch personeel variabel te willen gaan inzetten doen dit om flexibilisering van de productie te bewerkstelligen (47\%). Een ander doel, het verbeteren van de kwaliteit van de producten, speelt voornamelijk bij de andere organisatorische veranderingen een grote rol. Bedrijven die aangeven in 2013 projectmatig te willen gaan werken, doen dit met name om de kwaliteit van hun producten te verbeteren $(47 \%)$. De taakintegratie over de afdelingen heeft daarentegen voornamelijk als doel om productiviteitsstijging te realiseren (47\% van de bedrijven). Ook de variabele inzet van het eigen technisch personeel moet in relatief veel bedrijven bijdragen aan een productiviteitsstijging (30\%). Bovendien is het invoeren van taakintegratie over de afdelingen de enige vernieuwing waarbij ook wel eens als hoofddoel genoemd wordt dat de werkgever er op de arbeidsmarkt aantrekkelijker van wordt. Met het werken in teams worden drie hoofddoelen beoogd die min of meer even vaak door bedrijven genoemd worden. Het gaat hier om het bewerkstelligen van een 
hogere productiviteit per werknemer (24\%), een kwalitatief hoogwaardigere werkgelegenheid (34\%) en een kwaliteitsverbetering van de producten (30\%). Uit Figuur 5.6 blijkt dus dat om verschillende doelen te bereiken, ook daadwerkelijk verschillende organisatorische innovaties vereist zijn.

\section{Figuur 5.6}

Hoofddoel van geplande organisatorische innovaties in 2013 (\% bedrijven die de desbetreffende verandering in 2013 willen doorvoeren)

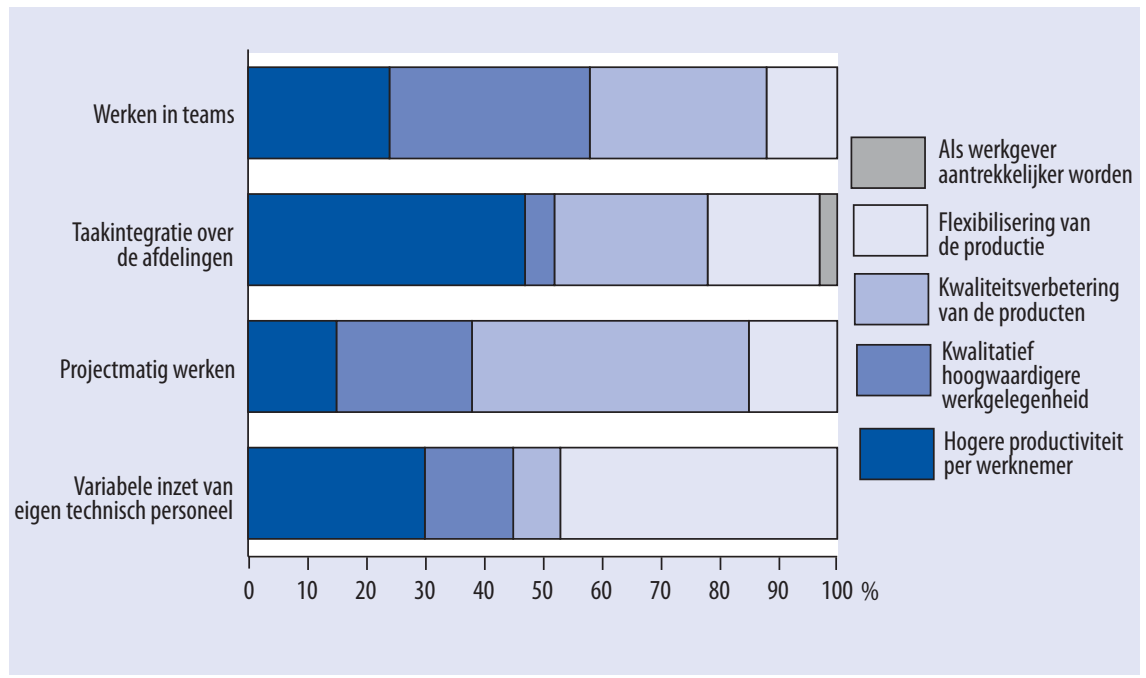

Bron: ROA, Arbeidsmarktmonitor Metalektro, 2012

\section{Veranderingen in menselijk kapitaal: Sterk stijgende behoefte aan breed inzetbare uitvoerende technici}

Vernieuwingen van het menselijk kapitaal van bedrijven hebben als doel (I) dat het menselijk kapitaal binnen bedrijven beter benut wordt en (2) dat het menselijk kapitaal an sich verder ontwikkeld wordt. Omdat in Hoofdstuk 4 al op dit laatste is ingegaan, beperken we ons hier tot de eerst genoemde vorm van vernieuwing. Meer in het bijzonder wordt hier ingegaan op de behoefte en beschikbaarheid van breed inzetbaar personeel. Hoewel de meeste medewerkers binnen de Metalektro gespecialiseerde vaardigheden en kennis hebben, blijkt er de laatste jaren toch ook duidelijk behoefte te zijn aan mensen die breder inzetbaar zijn. Met name tijdens de crisisjaren bleken bedrijven een grote behoefte te hebben aan mensen met een brede basis. In Figuur 5.7 is de ontwikkeling in de behoefte aan breed inzetbaar technisch personeel sinds 2008 weergegeven. ${ }^{\text {II }}$

II. De antwoordcategorieën bij de vraag naar de behoefte aan breed inzetbaar personeel zijn sinds 20 IO enigszins aangepast. In 2008 en 2009 waren de antwoordcategorieën: vaak, af en toe, zelden en nooit. Sinds 2010 zijn de antwoordcategorieën: in zeer sterkte mate, in sterke mate, in beperkte mate, in zeer beperkte mate. 
Figuur 5.7

Ontwikkeling van behoefte aan breed inzetbaar technisch personeel (\% bedrijven), 2008-2012

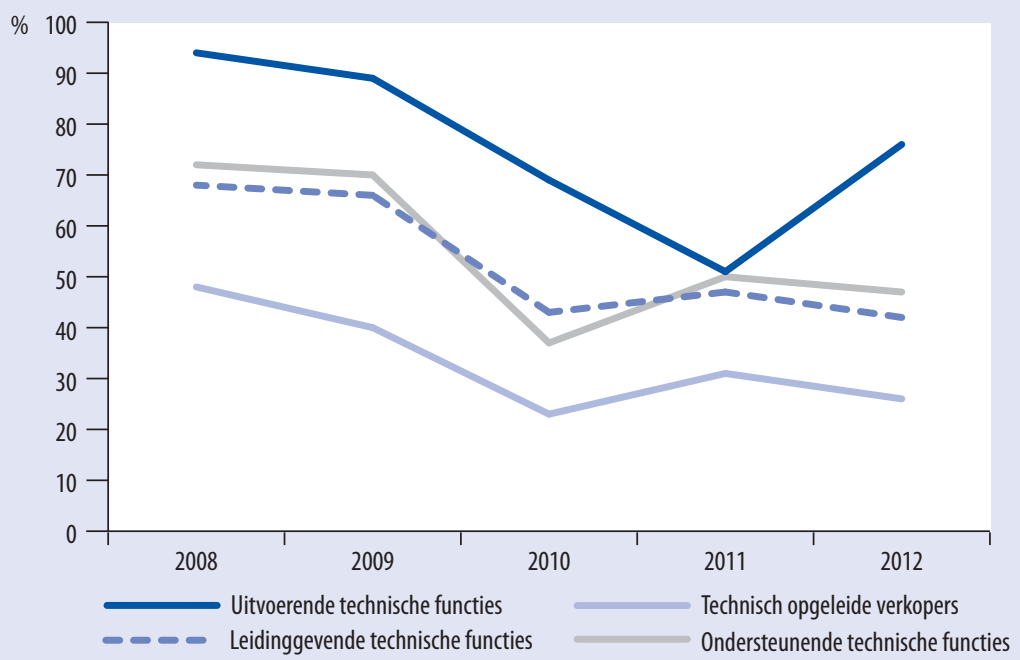

Bron: ROA, Arbeidsmarktmonitor Metalektro, 2008-2012

De figuur laat zien dat de behoefte aan breed inzetbaar technisch personeel in de eerste crisisjaren een stuk hoger lag dan in 20I0. Rond de $90 \%$ van alle bedrijven gaf in 2008 en 2009 aan geregeld behoefte te hebben aan breed inzetbaar uitvoerend technisch personeel. Ook onder de leidinggevende technische functies en technisch opgeleide verkopers was er een behoefte aan breed inzetbaar personeel (ongeveer bij $70 \%$ van de bedrijven). In 2010 zakte voor alle functiecategorieën de behoefte aan breed inzetbaar technisch personeel. Echter sinds 20 Io neemt de behoefte aan breed georiënteerde werknemers met ondersteunende technische functies weer toe. De behoefte aan breed inzetbaar uitvoerend technisch personeel is sinds $20 \mathrm{II}$ ook weer aangetrokken. Ruim drie van de vier bedrijven geeft aan in (zeer) sterke mate behoefte te hebben aan breed inzetbaar personeel in deze functiecategorie. Dit alles wijst er op dat een groot deel van de Metalektro een structurele behoefte heeft aan breed inzetbare technici, terwijl de behoefte bij $20 \%$ van de bedrijven vooral manifest wordt in een laagconjunctuur waarin het bedrijf medewerkers moet afstoten, waardoor een deel van de werkzaamheden door anderen moet worden overgenomen. De behoefte aan breed inzetbaar leidinggevend technisch personeel en technische opgeleide verkopers is stabiel sinds 2010 .

In Figuur 5.8 wordt nader aangegeven waar de behoefte tot breed inzetbare uitvoerende technici vandaan komt. De figuur laat het percentage bedrijven zien dat in 2012 een bepaalde reden aangeeft voor de behoefte aan breed inzetbaar personeel. Bijna 70\% van de bedrijven heeft breed inzetbare uitvoerende technici nodig om schommelingen in de bedrijfsdrukte op te vangen. Al sinds 2005 zijn schommelingen in de bedrijfs- 
drukte de hoofdreden achter de behoefte aan breed inzetbare uitvoerende technici. Door middel van breed inzetbaar personeel kunnen de conjuncturele schommelingen dus door het personeel opgevangen worden. Maar ook de vervanging van collega's tijdens afwezigheid door bijvoorbeeld verlof en ziekte wordt door meer dan 50\% van de bedrijven aangegeven als reden voor de behoefte aan breed inzetbaar uitvoerend personeel. Andere redenen die door minimaal één op de vier bedrijven genoemd in 2012 zijn; product- en/of procesvernieuwingen (4I\%), aantrekkelijker maken van de functies $(39 \%)$ en vergrijzing van het personeelsbestand $(28 \%)$.

Figuur 5.8

Redenen voor behoefte aan breed inzetbare uitvoerende technici, 2012

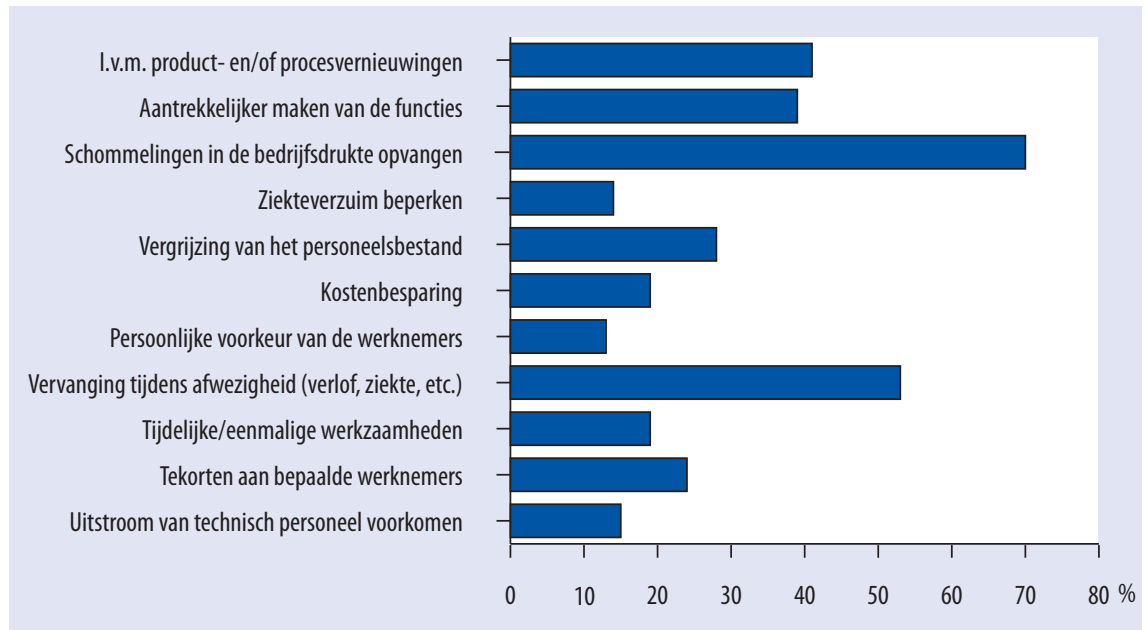

Bron: ROA, Arbeidsmarktmonitor Metalektro, 2012

Bedrijven hebben dus een aanzienlijke behoefte aan breed inzetbaar personeel, maar hebben ze ook de beschikking over genoeg van deze 'duizendpoten'? Zoals te zien is in Figuur 5.9 hebben bedrijven met name problemen met het breed inzetten van uitvoerende technici. Voor één derde van de bedrijven geldt dat het personeel onvoldoende breed inzetbaar is. Met andere woorden, binnen deze bedrijven is de behoefte aan breed inzetbare uitvoerende technici groter dan de beschikbaarheid ervan. Van het uitvoerend technisch personeel wordt dus verlangd dat zij hun kennis en vaardigheden uitbreiden op een manier die hen geschikt makkt voor een breder takenpakket. ${ }^{12}$ Voor de andere functiecategorieën binnen de Metalektro blijkt de discrepantie tussen de behoefte aan breed inzetbaar personeel en de beschikbaarheid hiervan stukken kleiner. Zo geeft respectievelijk $84 \%$ en $89 \%$ van de bedrijven aan dat hun personeel in leidinggevende en ondersteunende niet-technische functies voldoende breed inzetbaar is.

I2. Uit Figuur 4.9 blijkt dat bijna 30\% van de bedrijven taakroulatie toepast voor het technisch personeel. Dit is een manier om het technisch uitvoerend personeel breed inzetbaar te maken. 
Figuur 5.9

Verhouding tussen behoefte en beschikbaarheid breed inzetbaar personeel, 2012

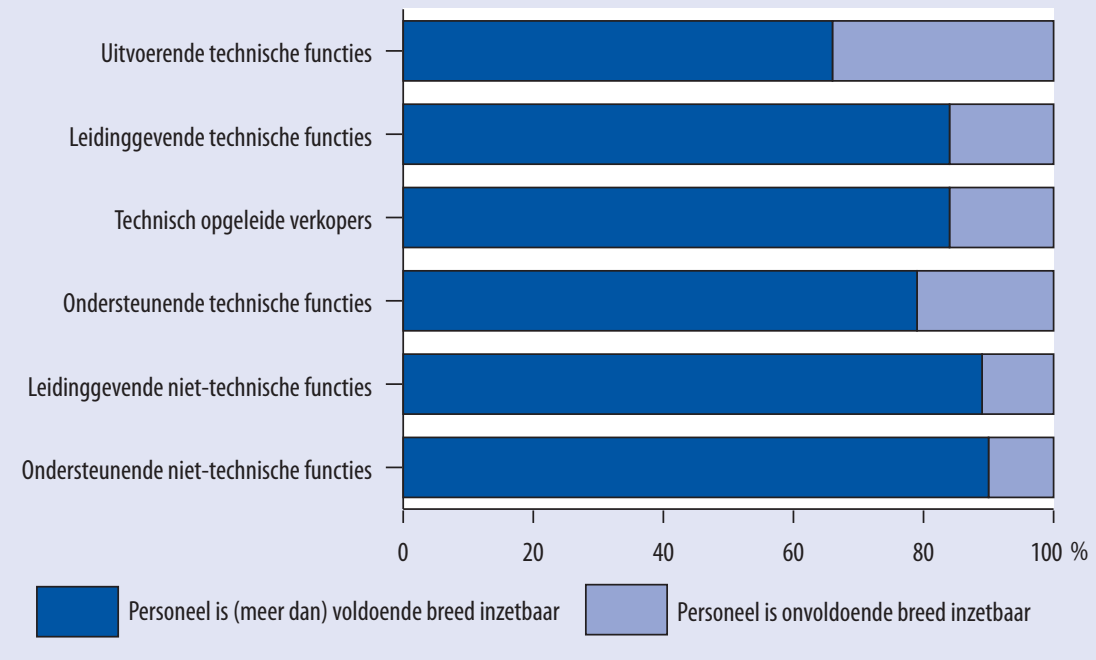

Bron: ROA, Arbeidsmarktmonitor Metalektro, 2012

\section{Externe samenwerking: Veel samenwerking binnen de sector, afname in uitbestedingen}

Organisatorische vernieuwingen beperken zich niet tot de interne organisatie en het ontwikkelen en benutten van het menselijk kapitaal dat in het bedrijf beschikbaar is. Bedrijven ontlenen immers hun bestaansrecht aan wat zij voor hun omgeving kunnen betekenen. Vernieuwingen in de externe samenwerking hebben betrekking op nieuwe vormen van samenwerking in de bedrijfsomgeving. Het kan dan gaan om allianties met andere bedrijven, maar ook om samenwerking met leveranciers, klanten en kennisorganisaties. Ook het intensiveren van externe betrekkingen of het veranderen van de manier waarop samenwerking plaatsvindt, biedt ruimte voor vernieuwingen.

Uit Figuur 5.Io is te zien dat er met name sprake is van externe samenwerking met andere bedrijven binnen de Metalektro sector en binnen de keten, bijvoorbeeld met klanten. Met het onderwijs wordt veel minder samengewerkt. Minder dan 30\% van de bedrijven werkt samen met een hogeschool/universiteit, een kennisinstituut of andere onderwijsinstellingen. Zoals we eerder in Figuur 5.2 zagen zit er momenteel ook weinig dynamiek in de externe samenwerking. Zo is slechts I2\% van de metalektrobedrijven in 2012 een nieuwe externe samenwerking aangegaan. 
Figuur 5.10

Vormen van externe samenwerking in 2012 (\% bedrijven)

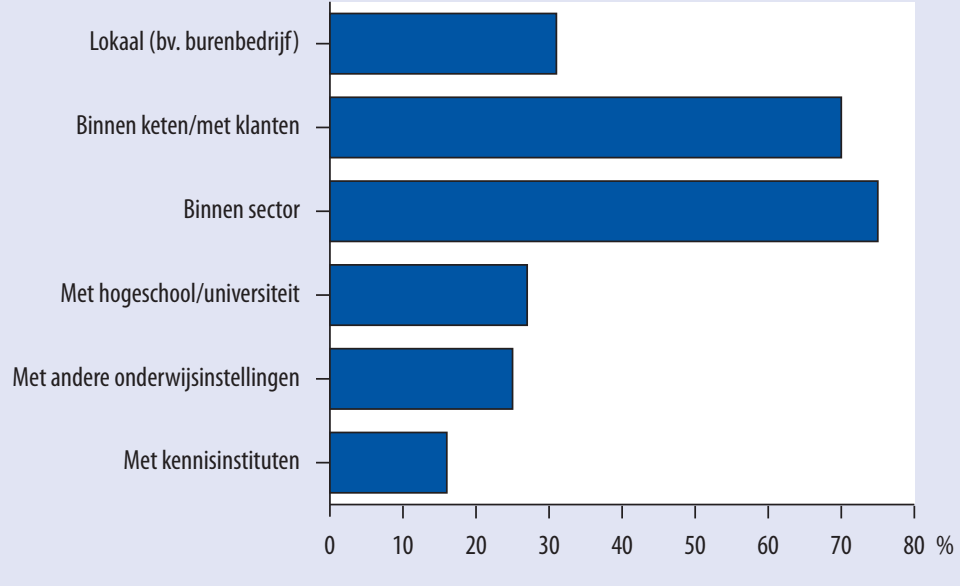

Bron: ROA, Arbeidsmarktmonitor Metalektro, 2012

We gaan nu kort in op een specifieke vorm van externe samenwerking: uitbesteding. Door uitbesteding is er automatisch sprake van een nauwe samenwerking tussen twee bedrijven. Uitbesteding kan zowel binnen als buiten Nederland plaatsvinden. De Figuren 5.II en 5.I2 laten de ontwikkeling van de geplande uitbestedingsactiviteiten voor de komende vijf jaar in de Metalektro zien. Uit de figuren valt af te lezen hoeveel procent van de metalektrobedrijven de komende jaren een afname of een toename in de uitbesteding van verschillende soorten activiteiten verwachten. Over het algemeen zien we dat de uitbesteding van activiteiten zowel binnen als buiten Nederland in de komende vijf jaar lijkt af te nemen.

Figuur 5.II laat zien dat meer dan één op de tien bedrijven verwacht minder productieactiviteiten en minder ondersteunende activiteiten uit te besteden aan andere bedrijven binnen Nederland. Er is geen sprake van een verschuiving van de uitbesteding van Nederlandse naar buitenlandse bedrijven want er zijn maar weinig bedrijven die een toename van de uitbesteding van deze activiteiten naar buitenlandse bedrijven verwachten (zie Figuur 5.I2).

De verwachte terugloop van de uitbesteding binnen de sector kan verschillende oorzaken hebben. Met name de afname in het uitbesteden van productieactiviteiten kan wijzen op pessimistische verwachtingen voor de omzetontwikkeling in de komende jaren. Als er minder vraag is naar producten, dan kan het terughalen van eerder uitbestede productieactiviteiten ervoor zorgen dat minder personeel zonder werk komt te zitten. Het kan echter ook zo zijn dat bedrijven simpelweg niet tevreden waren met de eerdere uitbesteding en dat zij liever weer zelf de verantwoordelijk nemen voor deze activiteiten. 


\section{Figuur 5.11}

Verwachte verandering in uitbesteding van activiteiten binnen Nederland in de komende vijf jaar

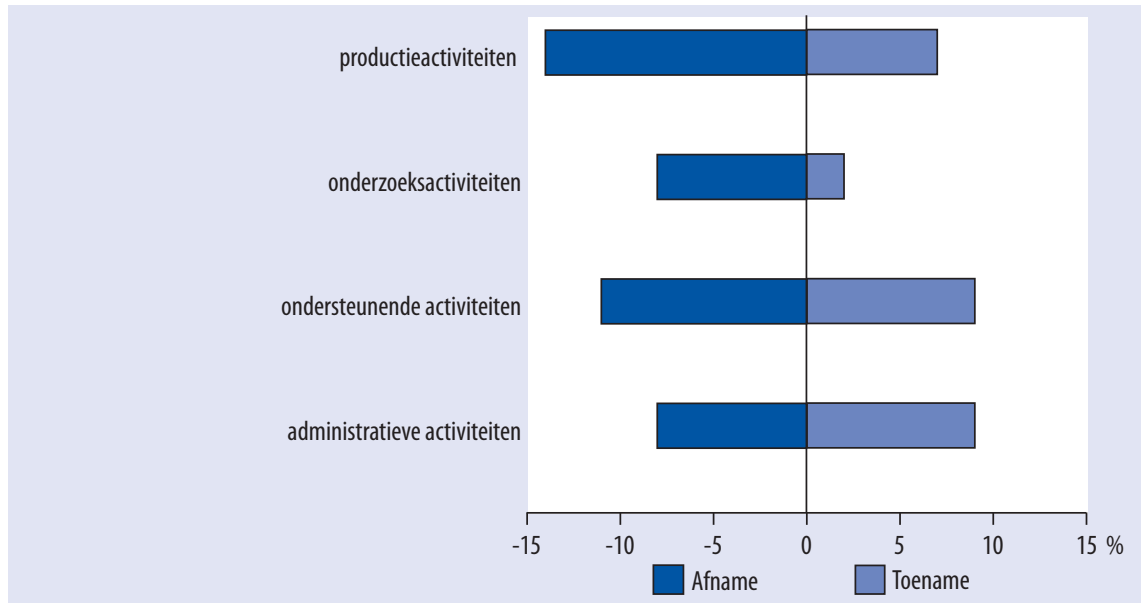

Bron: ROA, Arbeidsmarktmonitor Metalektro, 2012

\section{Figuur 5.12}

Verwachte verandering in uitbesteding van activiteiten buiten Nederland in de komende vijf jaar

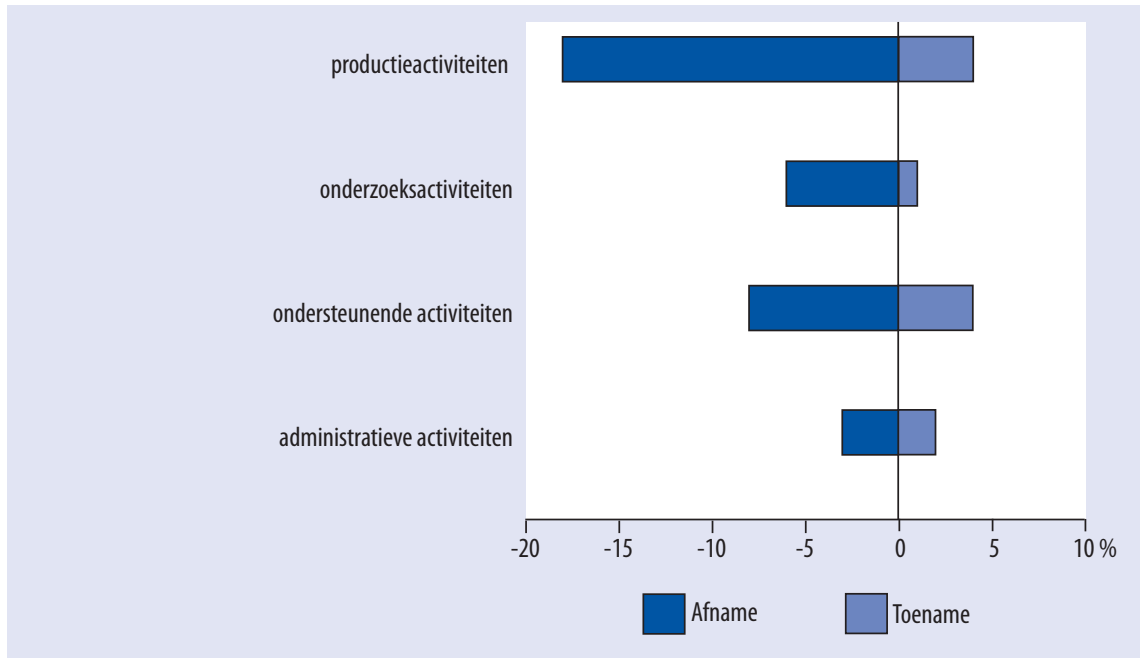

Bron: ROA, Arbeidsmarktmonitor Metalektro, 2012 


\section{Pensionering: verwachtingen en uitdagingen}

De Metalektro heeft te maken met vergrijzing van haar personeel. Echter, dit is niet terug te zien in de verwachte pensioenuitstroom. Er is namelijk al een aantal jaar een dalende trend in het percentage werknemers dat volgens de bedrijven de komende vijf jaar met pensioen gaat. Verrassend genoeg zijn de verwachte problemen met betrekking tot het vervangen van uittredend personeel de afgelopen jaren niet afgenomen. Sinds 2010 schommelt het percentage bedrijuen dat veel vervangingsproblemen verwacht rond de $30 \%$.

Bedrijven zijn in 2012 bewust bezig geweest om deze problemen te beperken. Meer dan 7 van de Io bedrijven heeft minimaal één HR instrument ingezet om hun personeel duurzaam inzetbaar te houden. Instrumenten die betrekking hebben op het menselijk kapitaal van de huidige werknemers zijn duidelijk het meest populair. Ook het aantrekken van nieuw personeel wordt door veel bedrijven gezien als een manier om de verwachte vervangingsproblemen in toom te houden. Het is daarom belangrijk dat er voldoende instroom van schoolverlaters is. 


\subsection{Onderschatten metalektrobedrijven de aanstaande pensioneringen?}

Zoals de meeste sectoren, heeft ook de Metalektro te maken met een vergrijzing van haar personeelsbestand. De gemiddelde leeftijd van de werknemers stijgt en daarmee ook het percentage werknemers dat in afzienbare tijd met pensioen gaat. Tenminste, dat zou men verwachten. Echter, uit Figuur 6.I blijkt dat bedrijven sinds de intrede van de crisis in 2008 in afnemende mate verwachten dat hun personeel binnen vijf jaar met pensioen gaat. Vooral het verwachte percentage werknemers in uitvoerende technische functies dat in de komende vijf jaar met pensioen gaat is erg afgenomen. Terwijl bedrijven in 2008 nog dachten dat $9 \%$ van hun uitvoerend technisch personeel binnen vijf jaar met pensioen zou gaan, is dat nu slechts $4 \%$. Voor al het andere technische personeel wordt een nog lager pensioenpercentage verwacht voor de komende vijf jaar. Bedrijven verwachten dat $3 \%$ van de technische leidinggevenden binnen vijf jaar met pensioen gaan. Dit is een kleine stijging ten opzichte van vorig jaar (in 20II: $2 \%$ ). Het percentage technisch opgeleide verkopers dat binnen vijf jaar met pensioen gaat wordt even hoog geschat als vorig jaar, $2 \%$. Het laagst verwachte pensioenpercentage wordt geobserveerd onder de ondersteunde technische werknemers: de verwachtingen zijn dat slechts I op de Ioo werknemers de komende vijf jaar met pensioen gaat.

\section{Figuur 6.1}

Verwacht percentage medewerkers dat de komende vijf jaar met pensioen gaat per technische functiecategorie, 2005-2012

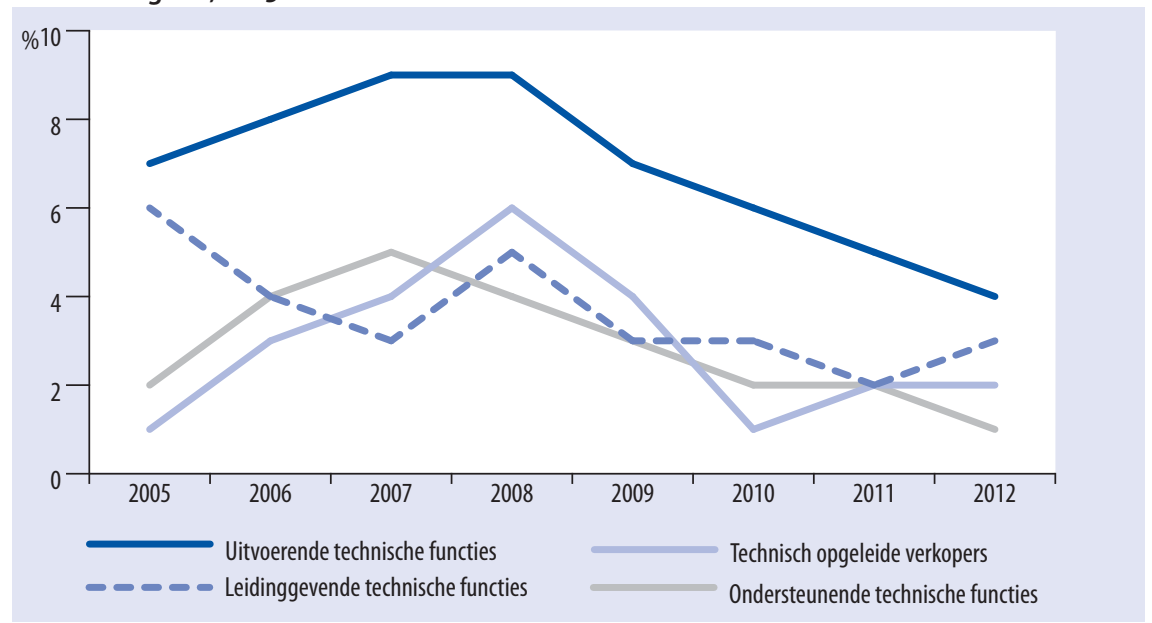

Bron: ROA, Arbeidsmarktmonitor Metalektro, 2005-2012

De observatie dat het percentage werknemers dat de komende vijf jaar met pensioen gaat al een aantal jaren daalt, terwijl de vergrijzing toeneemt, is contra intuïtief, maar kan verklaard worden door het naar achteren schuiven van de leeftijd waarop medewerkers met pensioen gaan. De bedrijven zijn de laatste jaren ook steeds meer gericht op duurzame inzetbaarheid, dit wil zeggen, het (productief) in dienst houden van 
relatief oudere werknemers (zie paragraaf 6.2). Dit is van groot belang, omdat oudere medewerkers door veranderingen in het pensioensysteem langer moeten doorwerken om de hoogte van hun pensioenuitkering in stand te houden of omdat de pensioengerechtigde leeftijd verandert. ${ }^{13}$ In beide gevallen is de verwachte uitstroom door pensionering lager omdat ouderen langer doorwerken en het moment van uittreding dus een aantal jaren naar achteren wordt geschoven. In combinatie met de huidige economische crisis ontneemt dit het zicht op de problematiek die zal ontstaan als de pensioenuitstroom de komende jaren zal toenemen.

Om een nog preciezer beeld te krijgen van de daadwerkelijke pensioneringspercentages in de komende jaren is inzicht in de leeftijdsverdeling van de Metalektrowerknemers noodzakelijk. Het percentage oudere werkenden in de sector geeft inzicht in de verwachtingen met betrekking tot de toekomstige personeelsuitstroom door pensionering. In Figuur 6.2 is op basis van de CBS Enquête beroepsbevolking (EBB) het percentage werkenden in de leeftijdscategorie 50-64 voor de Metalektro weergegeven sinds 2006 . We zien dat sinds 2006 het percentage ouderen is toegenomen. Terwijl in 2006 bijna $22 \%$ van de werkenden in de sector 50 jaar of ouder was, is dat percentage in $201 \mathrm{I}$ gestegen tot bijna $28 \%$. Ter vergelijking is in Figuur 6.2 ook het percentage ouderen in alle sectoren van de Nederlandse economie meegenomen. Ook hier is een duidelijke stijging zichtbaar. Opmerkelijk is wel dat het percentage ouderen over heel Nederland tot 20II hoger lag dan in de Metalektro. In 20II is het percentage ouderen echter voor het eerst hoger in de Metalektro dan gemiddeld in Nederland, wat overigens laat zien dat de metalektrobedrijven relatief succesvol zijn in het vasthouden van hun oudere personeel, maar aan de andere kant ook minder jongere medewerkers aantrekken.

13. Zie De Grip, Fouarge en Montizaan (2013) How sensitive are individual retirement expectations to raising the retirement age? ROA RM 2013/6. Hierin worden de laatste twee pensioenhervormingen in Nederland beschreven. Bovendien laten zij zien dat deze hervormingen inderdaad hebben geleid tot een toename in de verwachte pensioensleeftijd. 


\section{Figuur 6.2}

Percentage werkenden in de leeftijd 50-64 in de Metalektro en in alle sectoren in Nederland, 2006-2011

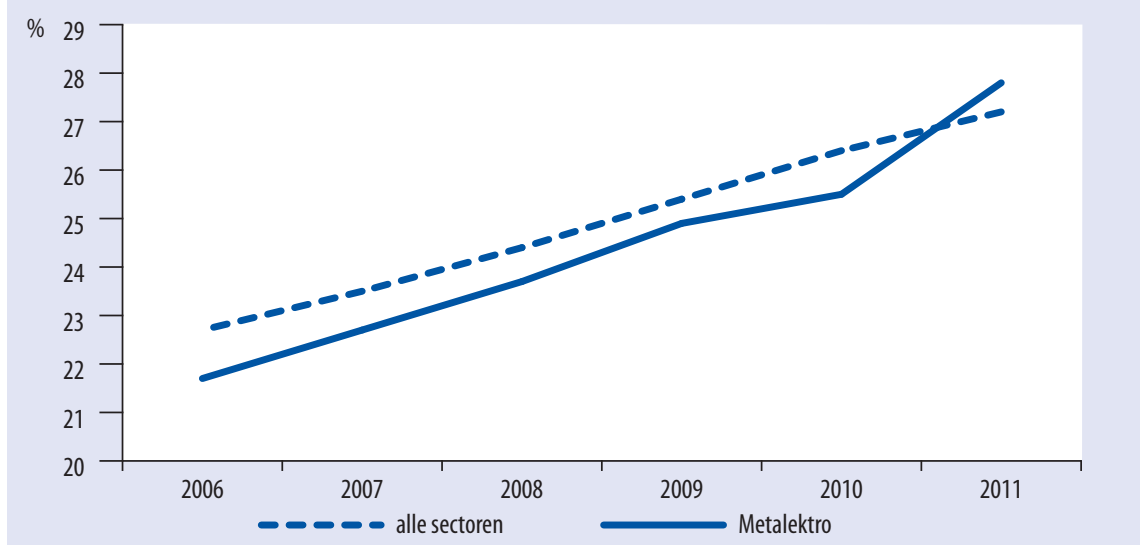

Bron: CBS, Enquête Beroepsbevolking (EBB), 2006-2011

Op basis van Figuur 6.2 is het dus te verwachten dat bedrijven in de Metalektro de komende jaren meer te maken krijgen met uitstroom vanwege pensionering. In hoeverre dit het geval is voor individuele bedrijven hangt natuurlijk af van de leeftijdsverdeling van het personeelsbestand op bedrijfsniveau. ${ }^{\mathrm{I}}$ Deze leeftijdsverdeling kan van vele factoren afhankelijk zijn. Zo blijkt uit Figuur 6.3 dat de leeftijdsverdeling verschillend is voor de verschillende sectoren binnen de Metalektro.

In Figuur 6.3 is het percentage ouderen per Metalektrosector weergegeven. In de basismetaal is het percentage ouderen al sinds 2006 het hoogst. Echter, sinds 2009 neemt het percentage ouderen in deze sector weer af. ${ }^{15}$ Voor de transportmiddelensector zien we een vergelijkbaar patroon. Voor bedrijven in deze sectoren is het dus goed mogelijk dat de uitstroom die zij verwachten door pensionering de laatste jaren is afgenomen. In de sectoren metaalproductie en elektrotechniek is het percentage ouderen sinds 2009 echter juist gestegen.

Zoals vermeld is een nadeel van het gebruik van de EBB data, dat niet te achterhalen valt wie in welk bedrijf werkzaam is en dat de data vooralsnog maar tot en met $201 \mathrm{I}$ beschikbaar zijn. Via het pensioenfonds van de Metalektro - PME - is deze informatie per bedrijf en voor 2012 echter wel verkregen. Door middel van deze data is het mogelijk om het percentage 55-59 en 60-64 jarigen voor 2012 in kaart te brengen. Dit is te zien in Figuur 6.4.

I4. Bovendien is het ook noodzakelijk te weten of het aantal werknemers binnen een bedrijf gelijk blijft. Als een bedrijf namelijk groeit en het aantal ouderen gelijk blijft, zal het percentage ouderen automatisch dalen en daardoor ook het verwachte percentage mensen dat met pensioen gaat.

15. In de basismetaal werken minder dan 30.000 werkenden. Daarom moeten deze gegevens met enige voorzichtigheid geïnterpreteerd worden. 
Figuur 6.3

Percentage werkenden in de leeftijd 50-64 in de verschillende Metalektrosectoren, 2006-2012

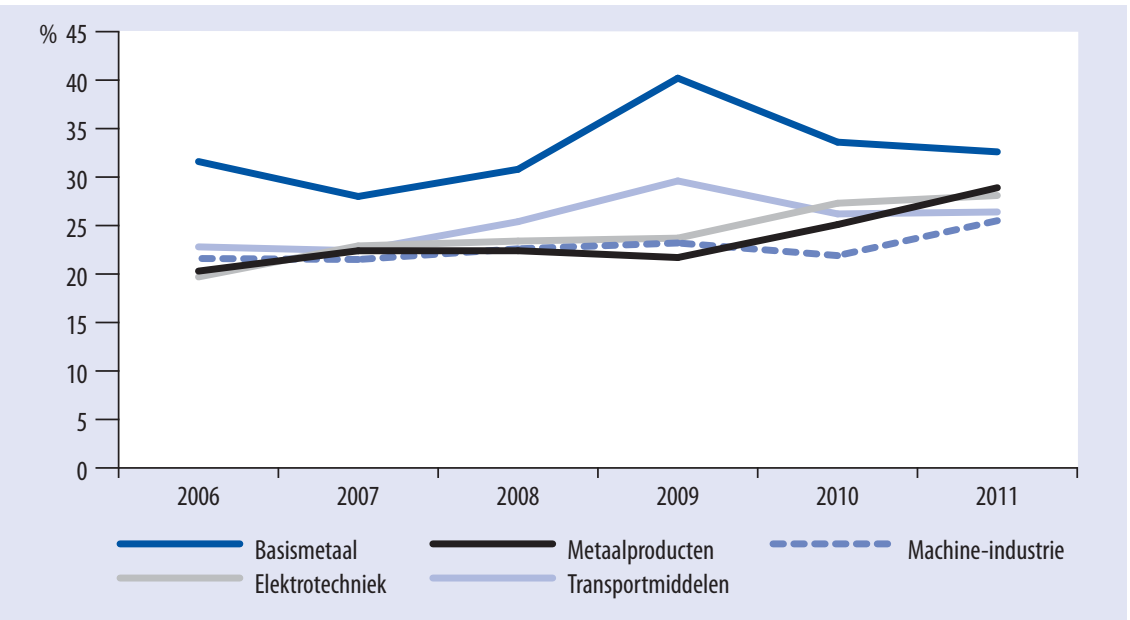

Bron: CBS, Enquête Beroepsbevolking (EBB), 2006-2011

Figuur 6.4

Gemiddeld percentage ouderen in de Metalektro, 2012

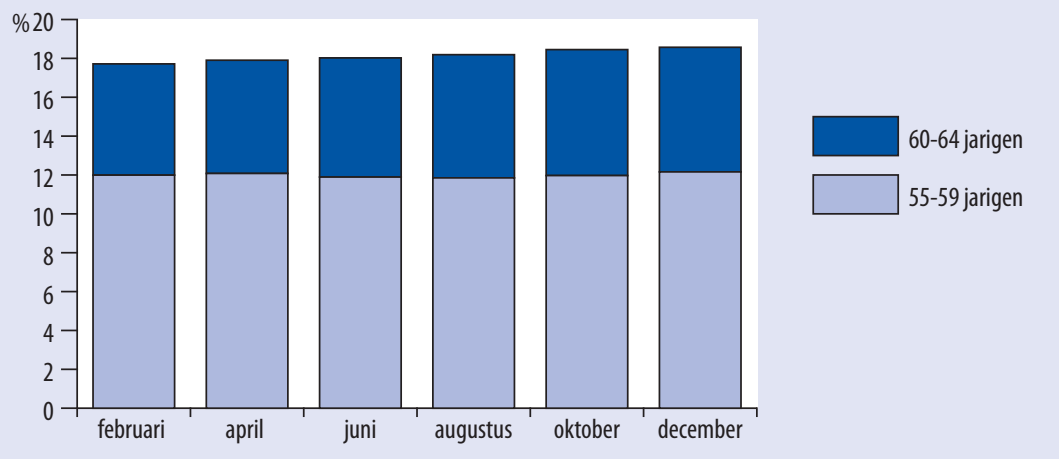

Bron: PME, 2012

Uit de figuur is op te maken dat in februari 2012 gemiddeld ruim 5\% van de medewerkers de leeftijd van 60 hebben bereikt. Dit percentage is in december 2012 tot ruim $6 \%$ opgelopen. Op basis van Figuur 6.4 kunnen we dus concluderen dat gemiddeld genomen minimaal $6 \%$ van de medewerkers binnen vijf jaar na 2012 met pensioen zullen gaan. Omdat het percentage medewerkers in de leeftijd van 55 tot 59 ongeveer $\mathrm{I} 2 \%$ is in $20 \mathrm{I} 2$ kan het percentage medewerkers dat met pensioen gaat in de vijf jaar na 2012 nog oplopen door vervroegde pensionering. $\mathrm{Al}$ met al is er dus een indicatie dat de metalektrobedrijven het verwachte pensioen percentage voor de komende vijf jaar onderschatten. 


\subsection{Vervangingsproblemen: verwacht en onverwacht}

Hoewel het verwachte percentage werknemers dat met pensioen gaat de komende vijf jaar is afgenomen, wil dit niet zeggen dat er nog geen problemen zijn om de mensen die met pensioen gaan, te vervangen. Naast de vergrijzing vindt namelijk ook een ontgroening van de samenleving plaats. Dit wil zeggen dat er steeds minder jonge mensen zijn, dus minder mensen die vanuit het onderwijs doorstromen naar de arbeidsmarkt. Dit wordt nog versterkt door de tekortschietende belangstelling voor het technisch onderwijs.

\section{Verwachte vervangingsproblemen}

Net als de voorgaande jaren is ook in 2012 aan bedrijven gevraagd naar de mate waarin zij de komende vijf jaar vervangingsproblemen verwachten door pensionering. In Figuur 6.5 wordt per technische functiecategorie het percentage bedrijven weergegeven dat aangeeft veel vervangingsproblemen te verwachten. Om een vergelijking te kunnen maken met de afgelopen jaren, is dit percentage vanaf 2007 meegenomen in de grafiek. In één oogopslag is te zien dat het percentage bedrijven dat in de komende vijf jaar veel vervangingsproblemen verwacht door pensionering in 2012 vrijwel gelijk is gebleven ten opzichte van 20II. Ondanks dat, zoals Figuur 6.I liet zien, het verwachte percentage mensen dat met pensioen gaat de afgelopen jaren is afgenomen worden er niet minder vervangingsproblemen verwacht.

Ongeveer 30\% van de bedrijven verwacht zelfs veel problemen bij het vervangen van het uitvoerend en leidinggevend technisch personeel dat met pensioen gaat. De verwachte problemen zijn duidelijk minder bij de technisch opgeleide verkopers en de ondersteunende technische functies. ${ }^{16}$ Ongeveer $15 \%$ van de bedrijven verwacht veel vervangingsproblemen voor deze functiecategorieën. De verwachte problemen bij de vervanging van technisch personeel zijn daarmee in 2012 nog steeds beduidend minder groot dan in 2007 en 2008 . Dit zal het gevolg zijn van de aanhoudende crisis, die ervoor zorgt dat bedrijven niet verwachten alle uitstroom als gevolg van pensionering te moeten vervangen en door het feit dat medewerkers enkele jaren later met pensioen gaan dan in het verleden.

I6. Hoogstwaarschijnlijk verwachten bedrijven minder problemen bij het vervangen van technisch opgeleide verkopers en de ondersteunende technische functies dan bij het vervangen van uitvoerende technische functies, omdat bedrijven al jaren de meeste wervingsproblemen ervaren voor de uitvoerende technische functies (zie Figuur 3.IO). In 2012 geeft $60 \%$ van de bedrijven aan problemen te hebben gehad om aan uitvoerende technici te komen. 


\section{Tekstbox 6.1 NedTrain anticipeert op toekomstige vervangingsvraag}

De tekorten aan technici die al jaren verwacht worden blijven tot op heden uit zegt Koen Sueters, Manager van de NedTrain TechniekFabriek. Hij wijdt dit aan een tweetal ontwikkelingen. Allereerst heeft de verhoging van de pensioensleeftijd naar 67 jaar gezorgd voor een vertraging van de uitstroom. Ten tweede heeft de economische crisis ervoor gezorgd dat (nog) niet alle gepensioneerden vervangen moeten worden door nieuwe medewerkers. Maar ook hier betekent uitstel geen afstel. Binnen NedTrain is de gemiddelde leeftijd van de 1400 monteurs 50 jaar en als gevolg daarvan gaat een grote golf medewerkers binnen afzienbare tijd met pensioen. $0 \mathrm{~m}$ voorbereid te zijn op het moment dat deze pensioneringsgolf aanbreekt en de economie weer is aangetrokken, leidt NedTrain nu al leerlingen op tot monteur via hun eigen bedrijfsschool de TechniekFabriek. Binnen de TechniekFabriek worden leerlingen in twee jaar tot monteur opgeleid. Deze tweejarige opleiding wordt afgesloten met een erkend diploma Mechatronica niveau 2 van ROC Twente en omvat daarnaast alle nodige stages en verder nog enkele NedTrain specifieke lesonderdelen. De opleiding wordt compleet door NedTrain betaald en biedt de afgestudeerden een baangarantie. Doordat de lessen zoveel mogelijk worden gegeven aan de hand van concrete voorbeelden uit het dagelijkse werk bij NedTrain, zijn afgestudeerden meteen volwaardig inzetbaar.

Als we Figuur 6.5 beter bekijken zien we echter toch kleine verschillen tussen de verwachting in $201 \mathrm{I}$ en 2012 . Het percentage bedrijven dat veel vervangingsproblemen verwacht voor het uitvoerend technisch personeel en technisch opgeleide verkopers is iets wat afgenomen tussen $201 \mathrm{I}$ en 20I2. Dit in tegenstelling tot het percentage bedrijven dat veel problemen verwacht in het vervangen van hun leidinggevend technisch en ondersteunend technisch personeel. De verwachte problemen voor deze laatstgenoemde twee functiecategorieën stijgen al sinds respectievelijk 20 Io en 2009 .

\section{Figuur 6.5}

Percentage bedrijven dat in komende 5 jaar veel vervangingsproblemen verwacht door pensionering, naar functiecategorie

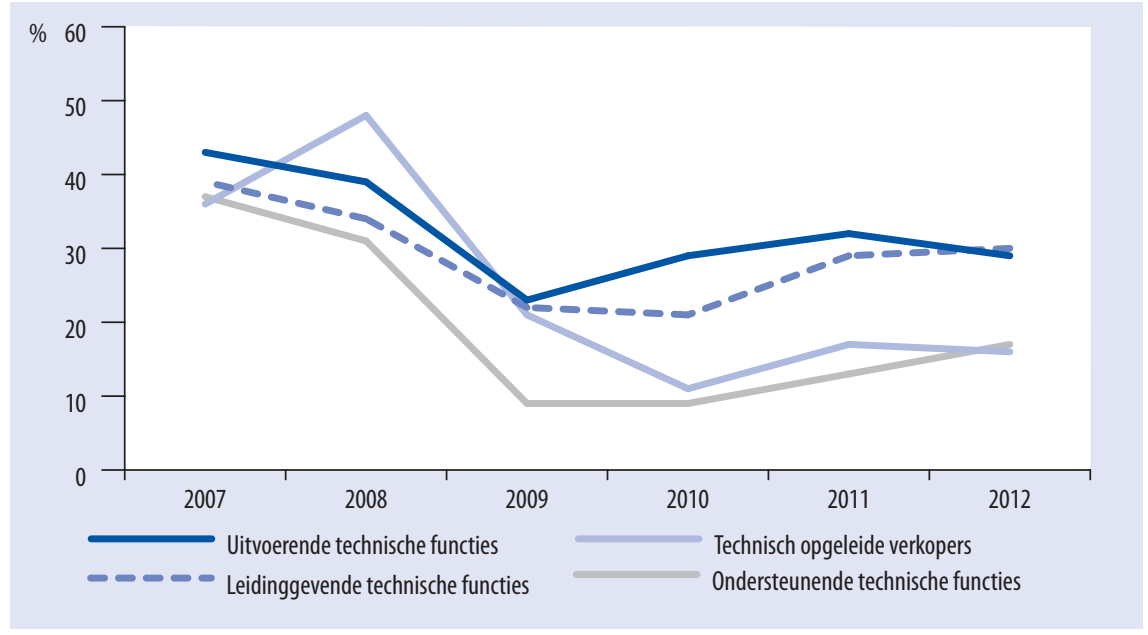

Bron: ROA, Arbeidsmarktmonitor Metalektro, 2007-2012 


\section{Van onderschatting pensioneringen tot additionele vervangingsproblemen}

Als vervanging van gepensioneerden nu en in de toekomst onderschat wordt kan dit de komende jaren leiden tot een onverwachte toename in het aantal moeilijk vervulbare vacatures als gevolg van pensioneringen. De gevolgen van moeilijk vervulbare vacatures waar bedrijven nu al mee kampen, worden door bedrijven op diverse manieren bestreden. Een van de meest populaire oplossingen heeft echter bij systematisch gebruik mogelijk gevolgen op de (middel)lange termijn. Meer dan de helft van alle bedrijven met moeilijk vervulbare vacatures blijkt vooral op het huidige personeel te steunen. ${ }^{17}$ In een poging met deze openstaande vacatures om te gaan wordt een beroep gedaan op het huidige personeel door middel van het draaien van overuren. Ruim $40 \%$ procent van de bedrijven met moeilijk vervulbare vacatures past deze interne aanpassing toe. ${ }^{\mathrm{I}}$ Hiermee is het laten draaien van overuren door technisch personeel de populairste interne maatregel onder bedrijven. Echter, internationale literatuur geeft aan dat het werken van overuren op termijn slecht is voor onder meer de baantevredenheid en gezondheid. ${ }^{19}$ Daardoor zien we dat mensen die langdurig overuren draaien vaker van werkgever wisselen en zelfs eerder met pensioen gaan. ${ }^{20}$ Dit kan leiden tot een vicieuze cirkel waarin allereerst moeilijk vervulbare vacatures leiden tot overuren onder het huidig personeel. Vervolgens kan dit leiden tot vervroegd pensioen of uittreding door ziekte wat wederom leidt tot (moeilijk vervulbare) vacatures. Het is daarom dubbel belangrijk dat bedrijven zich voorbereiden op de verwachte uitstroom van werknemers die met pensioen gaan. In de eerste plaats uit (direct) oogpunt van vervanging van de gepensioneerde en in de tweede plaats om het voorkomen van de vicieuze overwerk-cirkel die tot een additioneel vervangingsprobleem kan leiden.

\subsection{Meerderheid van metalektrobedrijven besteedt actief aandacht aan duurzame inzetbaarheid}

Naast het voorbereiden op toekomstige uitstroom, kunnen bedrijven zich ook richten op vertraging en spreiding van de pensioenuitstroom. Als oudere werknemers zich nog goed op hun plaats voelen binnen het bedrijf zullen zij over het algemeen minder snel met pensioen gaan. Bedrijven kunnen hier met hun HR beleid op inspelen. Om

I7. Uit Hoofdstuk 3 blijkt: I6\% van de bedrijven met moeilijk vervulbare vacatures past alleen interne maatregelen toe en $42 \%$ van alle bedrijven passen zowel interne maatregelen als ook maatregelen met betrekking tot werving en selectie toe.

I8. $58 \%$ van de bedrijven met moeilijk vervulbare vacatures past interne aanpassingen toe en daarvan geeft $73 \%$ aan deze openstaande vacatures op te vangen door het draaien van overuren onder het huidig technisch personeel.

19. Zie bijvoorbeeld: Kleppa et al. (2008) Working Overtime is Associated With Anxiety and Depression: The Hordaland Health Study, Journal of Occupational \& Environmental Medicine, Vol. 50(6): 658-666.

20. Zie bijvoorbeeld: Van den Berg et al. (20IO) Influence of Health and Work on Early Retirement, Journal of Occupational and Environmental Medicine, Vol. 52(6): 576-583. 
oudere werknemers langer aan het werk te houden is het van belang werknemers vitaal en inzetbaar te houden. Door het analyseren van de arbeidsbelasting en waar nodig het aanbieden van een aangepast takenpakket helpen werkgevers mee hun personeel vitaal te houden. Dat vitaliteit van het personeel niet onderschat wordt blijkt ook uit de HR speerpunten die bedrijven noemen: $30 \%$ van de bedrijven geeft aan dat het verminderen van ziekteverzuim één van de belangrijkste HR speerpunten in 2012 is. Om personeel productief inzetbaar te houden is een leven-lang-leren belangrijk, net als het aanbieden van functie- en taakroulatie en deeltijdpensionering. 65\% van de metalektrobedrijven gaf in 2012 aan HR beleid te voeren dat gericht is op het verbeteren van de duurzame inzetbaarheid van hun personeel. Dit is hoger dan de percentages bedrijven die in 2012 aangaven HR beleid te voeren ten behoeve van leeftijdsbewust personeelsbeleid (45\%) en levensfasebewust personeelsbeleid (33\%).

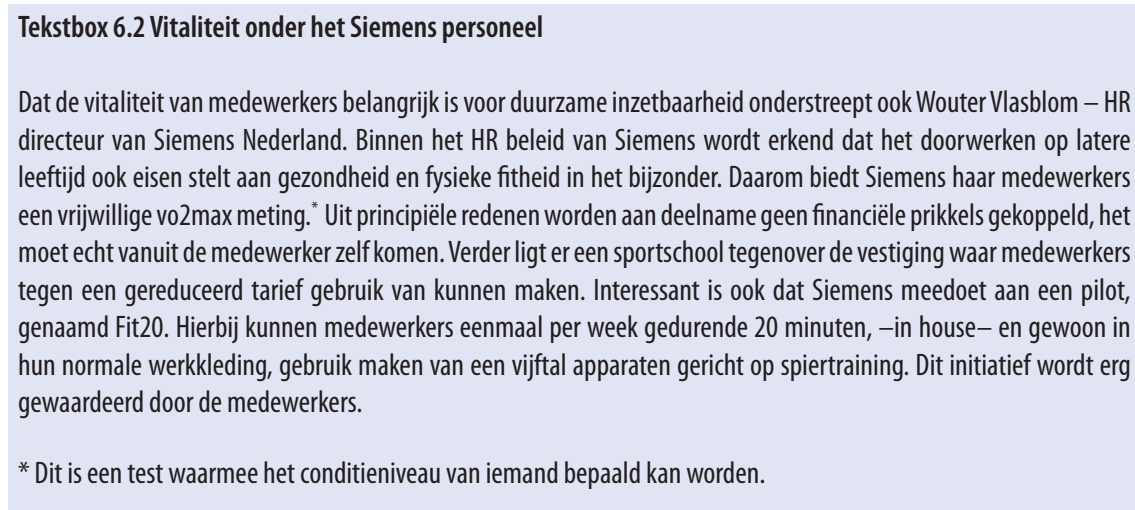

In Figuur 6.6 is een overzicht gegeven van active-ageing instrumenten, dat wil zeggen HR-instrumenten die bedrijven inzetten op het gebied van duurzame inzetbaarheid. Bijna alle bedrijven bieden opleidingsmogelijkheden aan. Dit draagt bij aan het productief houden van werknemers door middel van een leven-lang-leren. Meer dan $70 \%$ van de bedrijven is daarnaast ook bezig om op één of meerdere manieren hun personeel vitaal te houden. In deze context worden vaak de mogelijkheden aangeboden om werk te doen waarbij de focus ligt op het overdragen van kennis en om (gedeeltelijk) ander werk te verrichten (respectievelijk 78\% en $70 \%$ ). 


\section{Figuur 6.6}

Aangeboden HR-instrumenten met betrekking tot duurzame inzetbaarheid (\% bedrijven), 2012

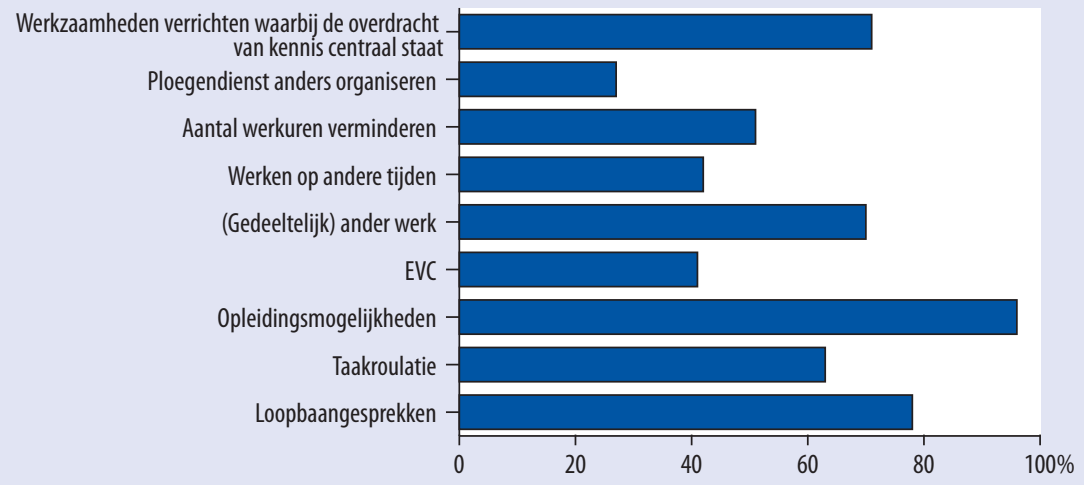

Bron: ROA, Arbeidsmarktmonitor Metalektro, 2012

In Figuur 6.7 vindt $\mathrm{u}$ het percentage bedrijven dat deze HR instrumenten relatief vaker inzet voor hun personeel dat ouder of jonger is dan 45 jaar. Meer dan $20 \%$ van de bedrijven geeft aan dat ze de mogelijkheid voor het uitvoeren van (gedeeltelijk) ander werk en het uitvoeren van werkzaamheden waarbij de overdracht van kennis centraal staat, vaker inzetten voor oudere werknemers. Ook het verminderen van het aantal werkuren komt bij IO\% van de bedrijven vaker voor onder werknemers boven de 45 jaar.

\section{Figuur 6.7}

Inzet van HR-instrumenten naar leeftijdsklasse (\% bedrijven), 2012

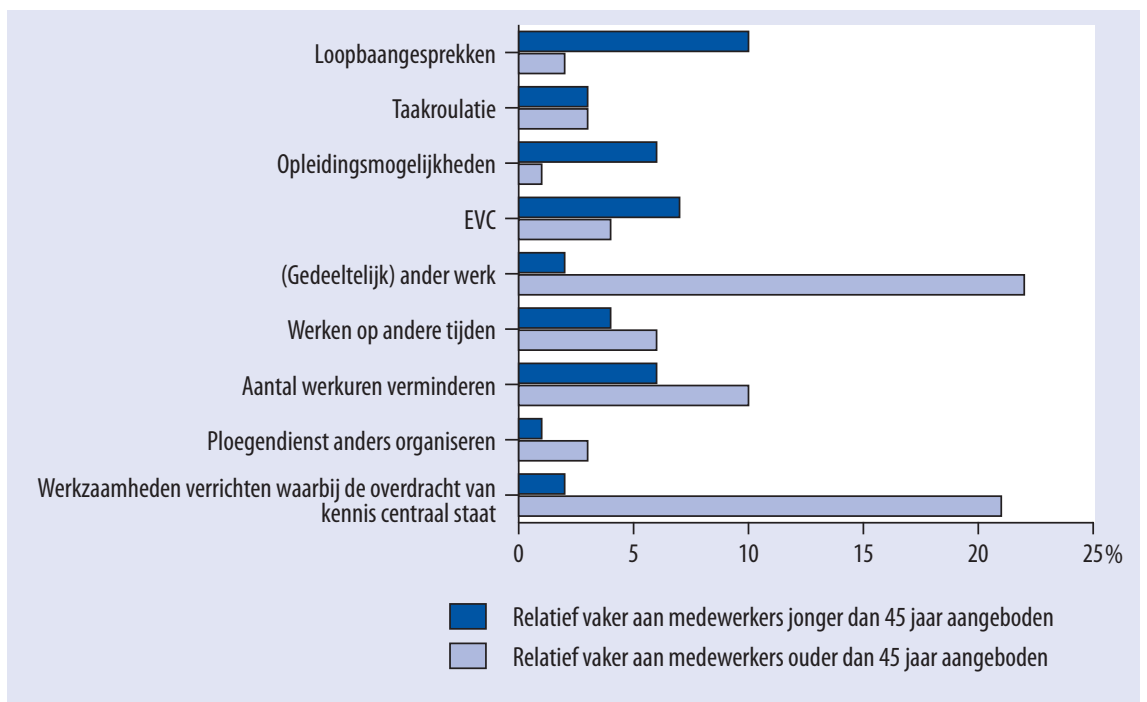

Bron: ROA, Arbeidsmarktmonitor Metalektro, 2012 
Hoewel bedrijven in de Metalektro niet zo vaak aanbieden om ploegendiensten anders te organiseren of op andere tijden te werken, worden deze twee maatregelen áls ze worden aangeboden vaker aangeboden aan oudere werknemers. HR maatregelen die meer betrekking hebben op opleiden en loopbaanontwikkeling worden daarentegen vaker aangeboden aan werknemers onder de 45 jaar.

\subsection{Grote regionale verschillen in aanpak vervangingsproblemen}

De in paragraaf 6.I beschreven bevindingen uit zowel het werkgeverspanel Metalektro 2012 als ook uit relevante internationale literatuur, wijzen er dus op dat bedrijven daadwerkelijk aan de slag moeten om vervangingsvraagproblemen voor te zijn. Zoals uit Figuur 6.6 blijkt wordt door middel van active-ageing instrumenten al gewerkt aan duurzame inzetbaarheid van het personeel. Echter, dit soort HR instrumenten kunnen alleen de verwachte vervangingsproblemen vertragen of spreiden, maar niet geheel oplossen. In deze paragraaf bekijken we andere maatregelen die metalektrobedrijven toepassen of willen gaan toepassen om grote vervangingsproblemen voor te zijn.

Uit het werkgeverspanel Metalektro blijkt dat ondanks grote verwachte vervangingsproblemen, er in Zuid- en Noordoost Nederland aanmerkelijk minder metalektrobedrijven momenteel al maatregelen hiertegen nemen dan in West-Nederland. Terwijl landelijk gezien in 2007 en 2008 zeven van de tien bedrijven maatregelen nam om de verwachte problemen met betrekking tot de vervangingsvraag te beperken, gaven in 2011 nog maar zes van de tien bedrijven aan dit soort maatregelen te treffen. In 2012 geeft wederom bijna zeven van de tien bedrijven aan dat zij reeds maatregelen nemen. Daarmee is het percentage bedrijven dat nu al bezig is de vervangingsvraag op te vangen weer gelijk aan het niveau van 2007 en 2008. Dit percentage is echter erg afhankelijk van de regio. Terwijl in West-Nederland 95\% van de bedrijven nu al maatregelen neemt om de vervangingsproblemen te beperken, is dit percentage in het Zuiden en het Noordoosten van het land slechts circa 50\%. ${ }^{21}$

In Figuur 6.8 wordt weergeven om welke maatregelen het precies gaat. Zoals uit hoofdstuk 4 en paragraaf 6.2 al bleek, investeren veel bedrijven in het menselijk kapitaal van hun huidige medewerkers. Uit Figuur 6.8 blijkt dat dit soort investeringen in het menselijk kapitaal ook ingezet worden om problemen met de vervangingsvraag van gepensioneerde technici te beperken. Het gaat hierbij om drie HR-maatregelen:

- Werknemers breed inzetbaar maken door taakroulatie (62\% van de bedrijven)

- Carrièreplanning van de werknemers stimuleren (40\% van de bedrijven)

- Het huidige personeel om- of bijscholen (50\% van de bedrijven)

2I. Dit lijkt niet te maken te hebben met de verwachte problemen met de vervangingsvraag. De verwachte problemen in het westen zijn niet anders dan die in andere delen van het land. 
Maar een nog groter percentage bedrijven probeert door het aantrekken van nieuwe werknemers de verwachte vervangingsproblematiek te beperken. Het gaat hier om het aannemen van schoolverlaters (47\%), het aannemen en zelf opleiden van nieuwe werknemers $(72 \%)$ en het aannemen van nieuw en goed opgeleide werknemers $(66 \%)$. Een beduidend kleiner percentage bedrijven werft tijdelijk extra personeel met als doel problemen met de vervangingsvraag van gepensioneerde technici te beperken $(20 \%)$. Nog minder populair is het verplaatsen van een deel van de productie naar het binnen- of buitenland. Er zijn maar weinig bedrijven die het verplaatsen van (een gedeelte van) de productie zien als een oplossing voor de problemen met de vervangingsvraag van gepensioneerde technici.

\section{Figuur 6.8}

HR-maatregelen om problemen met de vervangingsvraag van gepensioneerde technici te beperken (\% bedrijven), 2010-2012

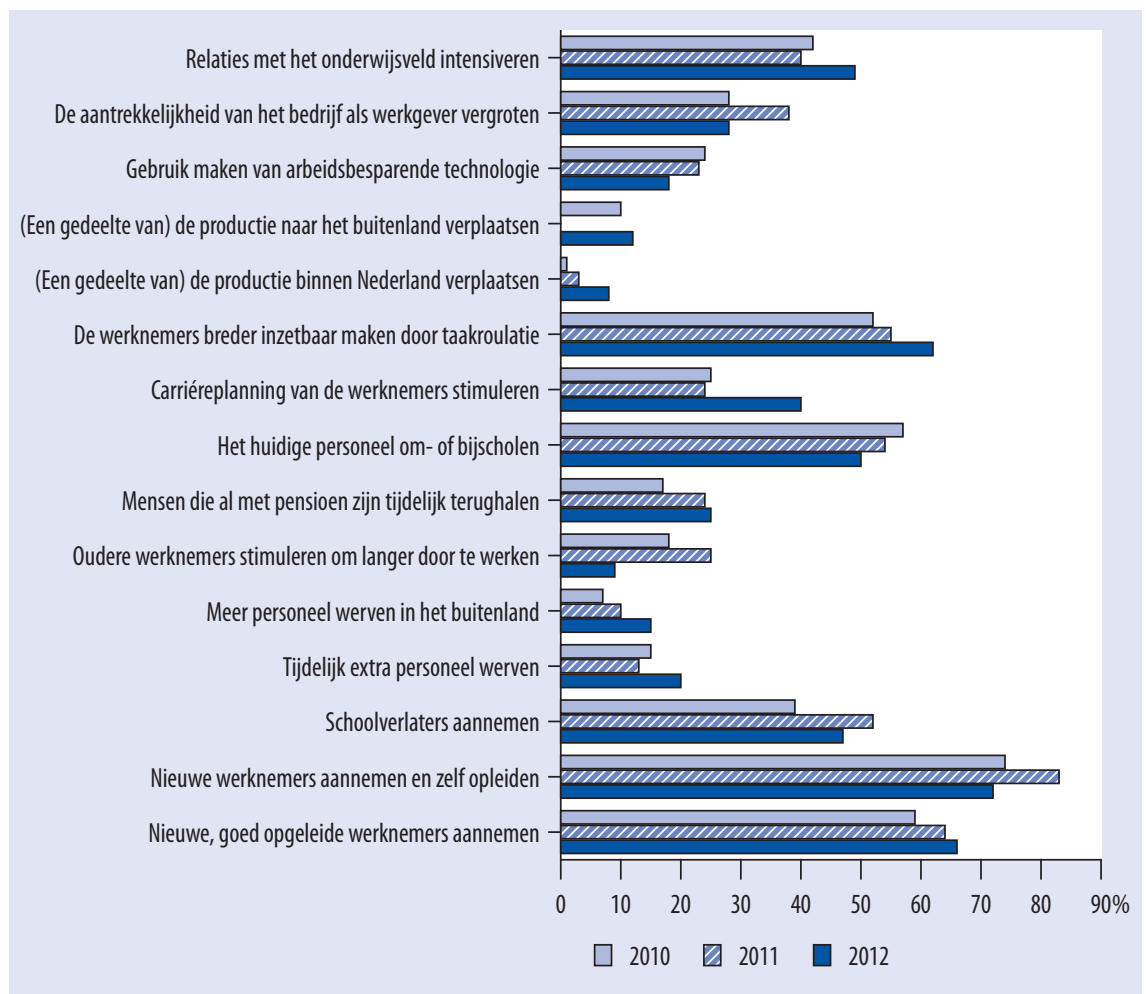

Bron: ROA, Arbeidsmarktmonitor Metalektro, 2010-2012 


\section{De Metalektro in de toekomst}

Verwachtingen van bedrijven wijzen erop dat werkgelegenheidsdaling uit de tweede helft van 2012 zal doorzetten in de eerste helft van 20I3. Voor specifieke functies zal er desondanks op de middellange tot lange termijn een aanzienlijk tekort ontstaan. Bedrijven verwachten dat technische functies in de toekomst meer allround zullen worden en dat meer verantwoordelijkheden zullen verschuiven naar technische functies op een lager niveau. Dit gaat gepaard met een toename van het belang van gedragsmatige competenties van medewerkers. Het is dan ook niet verbazend dat bedrijven hun personeelsbeleid in de toekomst vooral richten op het vergroten van de inzetbaarheid van hun personeel alsmede op het terugdringen van het verzuim. Om dit te realiseren wil men vooral met de medewerkers praten en afspraken maken in de vorm van functioneringsgesprekken, werkoverleg, beoordelingsgesprekken en persoonlijke ontwikkelplannen. Daarnaast zet ruim een derde van de bedrijven functieroulatie in als concreet middel om het personeelsbeleid vorm te geven. 


\subsection{Tot midden 2013 lijkt de werkgelegenheid in de Metalektro licht te dalen}

In Hoofdstuk 2 is te zien dat er ondanks de tegenzittende economische ontwikkelingen in 2012 in de Metalektro een lichte groei in de werkgelegenheid heeft plaatsgevonden. Dit was vooral te danken aan een positieve ontwikkeling in de eerste helft van 2012. De tweede helft van het jaar toonde een licht dalende werkgelegenheid. Hoe zet deze ontwikkeling zich door in 20I3? Figuur 7.I geeft de korte termijn werkgelegenheidsverwachting weer van metalektrobedrijven. Tijdens de vierde meting van 2012 is aan de bedrijven gevraagd voor de vier genoemde indicatoren aan te geven of deze in de eerste helft van 2013 zullen afnemen, gelijk blijven of toenemen. Voor alle indicatoren geldt dat veruit het grootste percentage bedrijven verwacht dat er geen veranderingen zullen optreden. Om een inschatting te maken van de korte termijn ontwikkelingen richten we ons op de bedrijven die aangeven een afname of toename te verwachten. Het percentage bedrijven dat verwacht dat de uitstroom zal toenemen is iets groter dan het percentage bedrijven dat verwacht dat de uitstroom zal afnemen. In totaliteit wijst dit alles op een verwachte netto uitstroom, met andere woorden: een negatieve werkgelegenheidsontwikkeling. Bij de instroom zijn de verschillen iets groter. Het percentage bedrijven dat verwacht dat de instroom zal toenemen is duidelijk kleiner dan het percentage bedrijven dat verwacht dat de instroom zal afnemen. Dit duidt op een verwachte netto daling in de instroom en daarmee wederom een negatief effect op de werkgelegenheid. Gevraagd naar hun verwachtingen voor de totale werkgelegenheid in hun bedrijf, zijn er eveneens meer bedrijven die krimp verwachten dan bedrijven die een toename in de werkgelegenheid verwachten. Hetzelfde geldt voor de verwachtingen over de vacatures.

Figuur 7.1

Verwachte werkgelegenheidsontwikkeling tot en met juni 2013

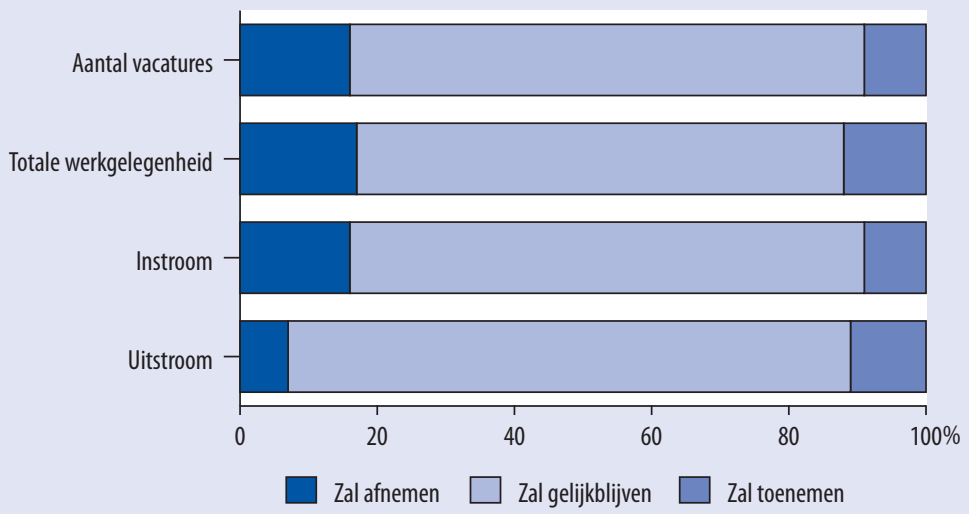

Bron: ROA, Arbeidsmarktmonitor Metalektro, 2012

Om nu al de conclusie te trekken dat dit alles wijst op een verwachte daling in werkgelegenheid in de sector is nog te vroeg. Het zou in het uiterste geval namelijk zo kunnen 
zijn dat alle bedrijven die verwachten dat hun totale werkgelegenheid zal afnemen kleine bedrijven zijn en dat alle bedrijven die verwachten dat hun werkgelegenheid zal toenemen grote bedrijven zijn. Dan zouden deze grote groeiende bedrijven, hoewel minder in aantal, waarschijnlijk een grotere impact hebben op de totale werkgelegenheid dan de vele krimpende kleine bedrijven. In Figuur 7.2 onderzoeken we dit in meer detail. Figuur 7.2 toont de verwachte werkgelegenheidsontwikkeling naar grootteklasse. We maken onderscheid tussen MKB bedrijven (<250 medewerkers) en grote bedrijven (250+ medewerkers).

Onder MKB bedrijven verwacht 73\% dat de werkgelegenheid in hun bedrijf gelijk blijft, $\mathrm{I} 6 \%$ verwacht een afname en $\mathrm{II} \%$ verwacht een toename. Er zijn dus meer MKB bedrijven die verwachten dat de werkgelegenheid daalt dan stijgt. Het percentage grote bedrijven dat verwacht dat de werkgelegenheid gelijk blijft is een stuk kleiner dan bij de MKB bedrijven, namelijk 57\%. Een daling in de werkgelegenheid wordt verwacht door $2 \mathrm{I} \%$ van de grote bedrijven, maar daar staat tegenover dat $22 \%$ van de grote bedrijven verwacht dat de werkgelegenheid in hun bedrijf zal toenemen. Onder grote bedrijven is het aantal bedrijven dat een toename en een afname van de werkgelegenheid verwachten dus bijna gelijk. De verwachte effecten van MKB en grote bedrijven bij elkaar opgeteld zijn er, zoals in Figuur 7.I te zien is, nog altijd meer bedrijven die een daling in hun werkgelegenheid verwachten dan bedrijven die een stijging verwachten, maar de opsplitsing naar grootteklasse laat zien dat er tussen MBK bedrijven en grote bedrijven een verschil in verwachte dynamiek is.

Als we de verwachtingen uit figuren 7.I en 7.2 met betrekking tot uitstroom, instroom, werkgelegenheid en vacatures overzien, lijkt het er toch op dat de licht dalende werkgelegenheid die heeft ingezet in de tweede helft van 2012 in de eerste helft van 2013 zal doorzetten.

\section{Figuur 7.2}

Verwachte werkgelegenheidsontwikkelingen naar bedrijfsgrootte tot en met juni 2013

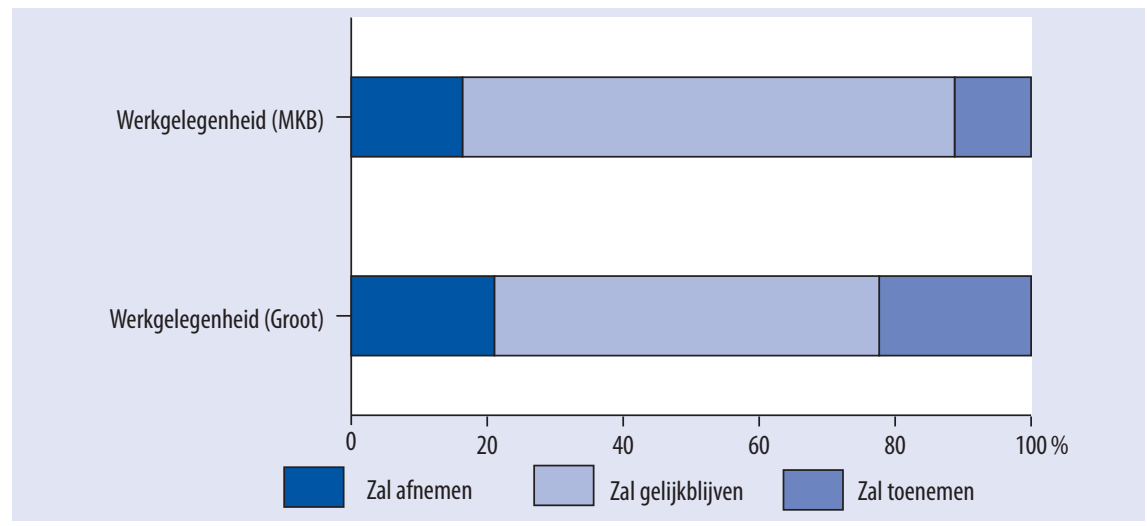

Bron: ROA, Arbeidsmarktmonitor Metalektro, 2012 


\subsection{Op de middellange termijn worden tekorten verwacht voor specifieke kwalificatiegebieden}

Hoewel de verwachtingen voor de korte termijn ontwikkelingen voor de sector als geheel op een kleine daling in de werkgelegenheid wijzen, zijn er zoals ook in Hoofdstuk 3 te zien is nog altijd veel bedrijven die moeite hebben om vacatures te vervullen met geschikte medewerkers. Dit is consistent met het beeld dat uit ROA prognoses voor 2016 naar voren komt. ${ }^{22}$ Hierin worden namelijk tekorten verwacht voor medewerkers met diverse technische achtergronden. Wanneer deze tekorten zich precies zullen openbaren is moeilijk aan te geven. Dit hangt natuurlijk sterk samen met de macro-economische en sectorale ontwikkelingen.

Tabel 7.I toont voor de technische opleidingen die voor de Metalektro belangrijk zijn de omvang van het verwachte tekort ten opzichte van het totaal aantal werkenden in Nederland met de desbetreffende opleidingsachtergrond. Daarnaast toont de tabel met hoeveel procent de arbeidsmarktinstroom vanuit de opleidingen zou moeten stijgen om het verwachte tekort te neutraliseren. We bespreken hieronder een aantal kwalificaties.

Tabel 7.1

Prognose van tekort als percentage van totaal aantal werkenden per opleidingsrichting 2016

\begin{tabular}{lcc|} 
& Tekort als $\%$ van werkenden & Verhogen instroom vanuit opleidingen? \\
\hline VMBO metaal & $22 \%$ & $221 \%$ \\
\hline VMB0 elektrotechniek & $14 \%$ & $94 \%$ \\
$\begin{array}{l}\text { MBO werktuigbouw en } \\
\text { mechanische techniek }\end{array}$ & $22 \%$ & $96 \%$ \\
\hline $\begin{array}{l}\text { MBO fijnmechanische } \\
\text { techniek }\end{array}$ & $18 \%$ & $42 \%$ \\
\hline MBO elektrotechniek & $16 \%$ & $25 \%$ \\
\hline MBO procestechniek & $-11 \%$ & \\
& & $20 \%$ \\
\hline HBO werktuigbouwkunde & $17 \%$ & $63 \%$ \\
\hline HBO elektrotechniek & $16 \%$ & \\
\hline
\end{tabular}

Bron: ROA, Arbeidsmarkt naar opleiding en beroep tot 2016.

Voor MBO werktuigbouw en mechanische techniek is het verwachte tekort voor 2016 $22 \%$. Op basis van de verwachte instroom vanuit opleidingen tot 2016 is af te leiden dat de instroom bijna zou moeten verdubbelen om het verwachte tekort teniet te doen. Voor MBO elektrotechniek is het verwachte tekort voor 2016 I6\%. Vanuit deze opleiding worden naar verhouding echter meer instromers verwacht op de arbeidsmarkt, waardoor verhoging van deze instroom met een kwart het verwachte tekort al kan tegengaan.

22. De Arbeidsmarkt naar opleiding en beroep tot 20I6. ROA-R-20II/8, Maastricht. 
Tekstbox 7.1 Anticyclisch mensen aantrekken met het oog op toekomstige tekorten; de afwegingen bij NedTrain en Siemens

In het voorbeeld van NedTrain in paragraaf 6.2 was al te zien dat zij, ondanks het uitblijven van grote tekorten op dit moment, al met het oog op de toekomst investeren in het opleiden van jonge mensen tot de technici die ze straks nodig hebben. Koen Sueters, manager van de NedTrain TechniekFabriek geeft aan waarom ze daarvoor kiezen, maar ook dat dit op korte termijn voor uitdagingen zorgt: "Ondanks dat we nu eigenlijk meer mensen hebben dan waarvoor werk is, gaan we anticyclisch door met de TechniekFabriek. Als de pensioneringsgolf aanbreekt en daarbij ook de economie weer is aangetrokken, moeten we voorbereid zijn. Dat is wat we met lange termijn denken bedoelen. Als we daar nu niet al op inspelen, krijgen we straks echt een probleem om de trein op de rails te krijgen. Door de baangarantie moeten we nu diegenen die van de TechFabriek afstuderen een baan geven, wat op dit moment dus bovenformatief moet gebeuren. Tja, dat is op korte termijn even een uitdaging, maar op de lange termijn is dit het concept waar we in geloven en wat volgens ons goed werkt om in onze toekomstige personeelsbehoefte te kunnen voorzien."

Bij Siemens Nederland is vanuit HR perspectief ook nadrukkelijk oog voor de optie om anticyclisch personeelsbeleid te voeren, maar daarbij wordt wel een belangrijke kanttekening geplaatst vanuit corporate oogpunt. Wouter Vlasblom - HR directeur van Siemens Nederland zeg daarover:

"Vanuit HR perspectief zou je op dit moment, nu je praktisch kunt kiezen uit de beste schoolverlaters, meer jonge talenten binnen willen halen. Dit zou HR doelstellingen, die zich veelal op de lange termijn bewegen, helpen te behalen. Denk hierbij aan een bepaald streven voor een gemiddelde leeftijd binnen het bedrijf. Echter, vanuit corporate oogpunt wordt gestuurd op head-count en wordt gewerkt met centrale budgeten. Hierdoor kun je niet altijd zoveel jonge talenten aantrekken als je vanuit HMR perspectief misschien zou willen met het oog op de toekomst. Dit leidt soms tot discussies. Naarmate er minder vacatures zijn leidt dit tot een groter spanningsveld."

\subsection{Technische functies zullen meer allround worden en meer verantwoordelijkheden omvatten}

In de Hoofdstukken 5 en 6 is al aan bod gekomen welke organisatorische veranderingen Metalektro bedrijven voor de komende jaren verwachten. Door veel bedrijven wordt aangegeven dat de komende jaren onder meer wordt ingezet op variabele inzetbaarheid van medewerkers, taakroulatie en projectmatig werken. Dit heeft gevolgen voor de eisen die aan technisch personeel worden gesteld. Aan de bedrijven is daarom gevraagd aan te geven of ze de komende vijf jaar veranderingen verwachten in de functies van het technisch personeel en welke veranderingen dit dan zijn. Men kon meerdere antwoorden tegelijk aanvinken. In Figuur 7.3 zijn de resultaten weergegeven en vergeleken met de antwoorden die in $201 \mathrm{I}$ en 2010 werden gegeven. Een stijgend percentage van de bedrijven (46\%) geeft aan dat ze de komende jaren geen veranderingen verwachten in de functies van hun technisch personeel. De meerderheid van bedrijven verwacht dus wel een of meerdere veranderingen de komende jaren. Meer dan de helft van de bedrijven verwacht dat technische functies meer allround zullen worden en dat meer verantwoordelijkheden in de technische functies op een lager niveau in de organisatie komen te liggen. Deze beide ontwikkelingen vragen een bredere inzetbaarheid van de medewerkers. Een ruime meerderheid van 
de bedrijven verwacht ook nog altijd dat gedragsmatige competenties belangrijker worden, ondanks dat dit percentage een paar procenten is gedaald ten opzichte van voorgaande jaren. Deze ontwikkelingen samen maken dat technische functies veeleisender zullen worden.

\section{Figuur 7.3}

Verwachte veranderingen in de functies van het technisch personeel in de komende 5 jaar (\% bedrijven).

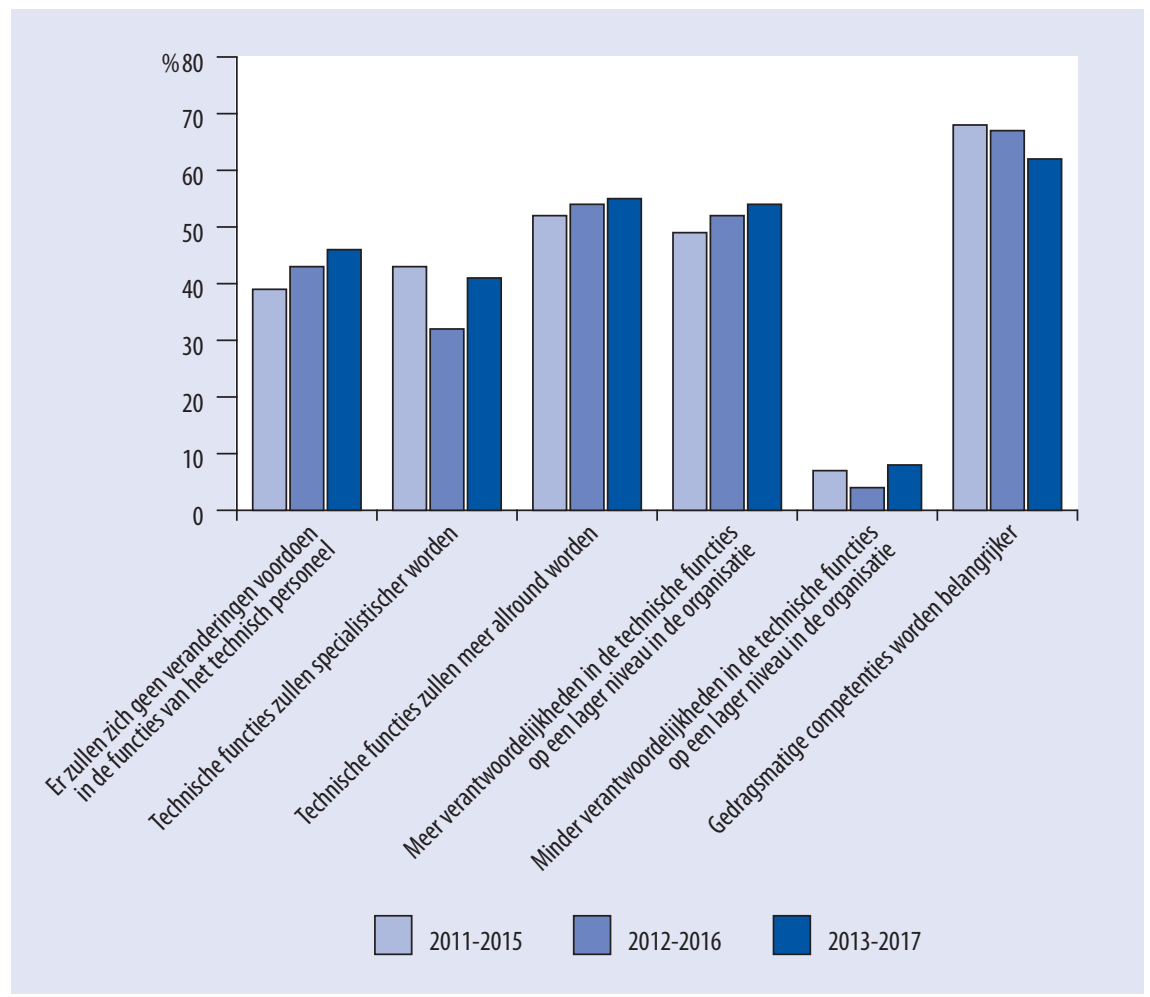

Bron: ROA, Arbeidsmarktmonitor Metalektro, 2010-2012

Tekstbox 7.2 Randstad Techniek constateert dat ook aan uitzendkrachten steeds hogere eisen worden gesteld.

De verwachte veranderingen in technische functies die metalektrobedrijven voor de komende jaren voorzien leiden niet alleen tot toenemende eisen aan hun eigen personeel. 0ok wanneer bedrijven flexibele krachten inhuren worden er steeds hogere eisen aan deze krachten gesteld. Dit wordt onderstreept door Klaas Trienekens en Carlo Hurkmans, respectievelijk loopbaanadviseur en intercedent technisch personeel bij Randstad Techniek in Eindhoven. Zij ervaren in de praktijk dat er in toenemende mate een hoger niveau van flexibele krachten gevraagd wordt. Waar vroeger voor bepaalde functies volstaan kon worden met lager opgeleide flexibele krachten, worden tegenwoordig al snel personen gevraagd met mbo+ niveau. Dit is volgens Klaas Trienekens en Carlo Hurkmans grotendeels ingegeven door technologische veranderingen die een steeds hoger niveau van de flexibele krachten vereisen. 


\subsection{Bevorderen van inzetbaarheid en verminderen van verzuim zijn grote speerpunten $\mathrm{t} / \mathrm{m} 2017$}

Diverse van de hierboven besproken verwachte veranderingen in functies stellen hogere eisen aan de brede inzetbaarheid van medewerkers. Geheel in lijn hiermee is dan ook dat een ruime meerderheid van bedrijven in de Metalektro aangeeft dat het bevorderen van de inzetbaarheid van het personeel een speerpunt is van het personeelsbeleid. Dit is te zien in Figuur 7.4. Andere speerpunten die de top vijf van meeste genoemde speerpunten completeren zijn het verminderen van verzuim, het bevorderen van coachend leiderschap, leeftijdsbewust personeelsbeleid en het stimuleren van cursusdeelname. Zowel het bevorderen van de inzetbaarheid van het personeel, als het verminderen van verzuim staan al jaren bovenaan de lijst met speerpunten. Bij Siemens Nederland is het ziekteverzuim slechts $1,9 \%$. In tekstbox 7.3 staat een deel van hun aanpak beschreven.

\section{Figuur 7.4}

Toekomstige speerpunten personeelsbeleid van bedrijven (\%)

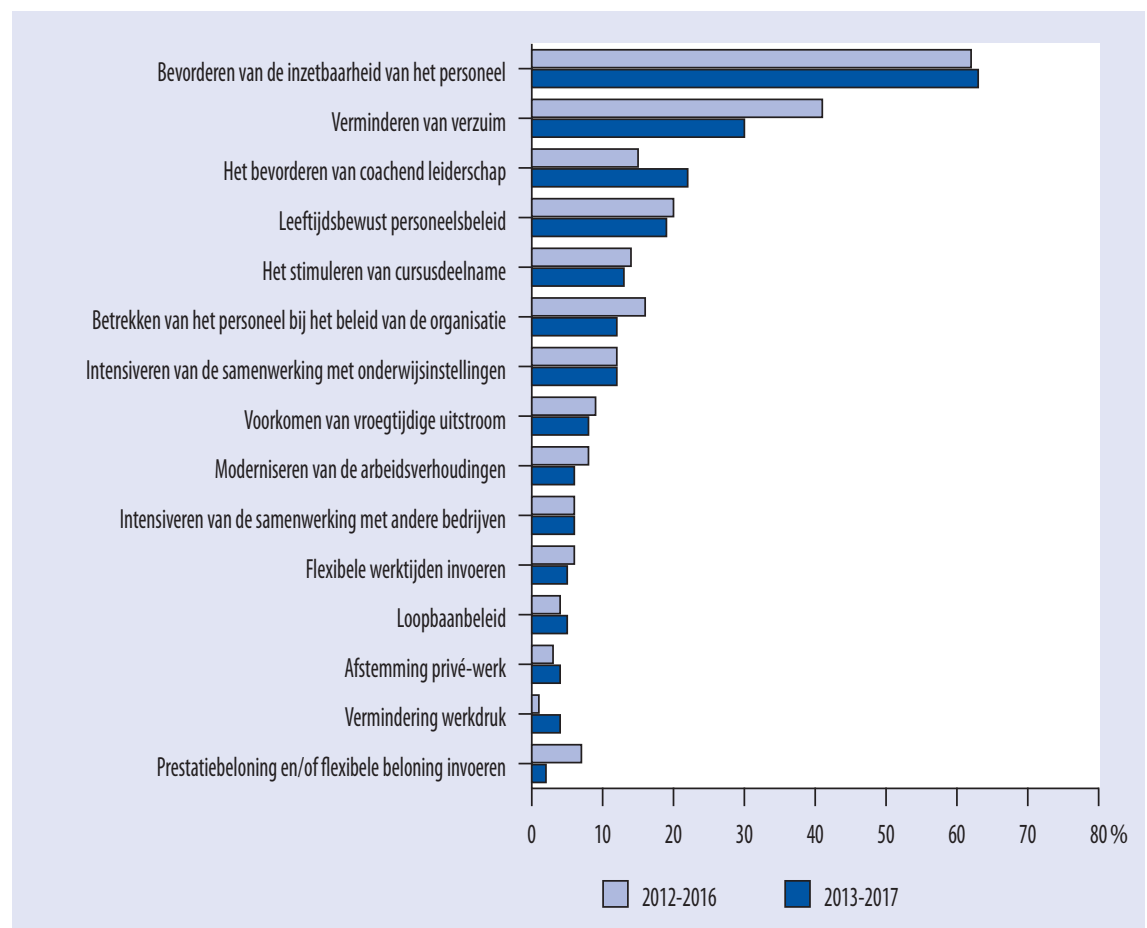

Bron: ROA, Arbeidsmarktmonitor Metalektro, 2011-2012 


\section{Tekstbox 7.3 Een laag ziekteverzuim: een voorbeeld van een van de maatregelen van Siemens Nederland}

Zeer opvallend is het lage ziekteverzuimcijfer binnen Siemens Nederland. Op dit moment is het verzuimpercentage slechts 1,9\% en dalende, aldus Wouter Vlasblom - HR directeur van Siemens Nederland. Dit wordt toegeschreven aan het motivatiebeleid en aan preventie. Het management is hiervoor verantwoordelijk gemaakt. Het begint met de manier van ziekmelden, een mailtje naar het secretariaat volstaat niet. Je dient ook je manager telefonisch op de hoogte te stellen en vragen te beantwoorden als 'hoe lang denk je afwezig te zijn?'. Is een medewerker langer dan een week ziek dan moet hij een vragenformulier invullen en hetzelfde geldt voor de manager. De vragen die aan de manager worden gesteld, zijn van dien aard dat hij telefonisch met de zieke in contact moet treden om te weten wat hij moet invullen. Het zoveel mogelijk voorkomen van ziekteverzuim is belangrijk, omdat berekend is dat een verzuimcijfer van $1 \%$ de organisatie zo'n 1 tot 1,5 miljoen euro kost op jaarbasis, afhankelijk van welke kosten meegenomen worden.

Tot slot merken we bij Figuur 7.4 op dat het bevorderen van coachend leiderschap sterk aan populariteit heeft gewonnen en daarmee ten opzichte van vorig jaar de derde plaats heeft overgenomen van leeftijdsbewust personeelsbeleid. Andere verschuivingen in de antwoord categorieën zijn minimaal.

Figuur 7.5 toont de HR instrumenten waarmee bedrijven de toekomstige speerpunten willen realiseren. Het meest populaire HR instrument dat wordt ingezet om de HR speerpunten te bereiken blijft het voeren van functioneringsgesprekken. Het voeren van werkoverleg en beoordelingsgesprekken blijven ook onverminderd belangrijk voor bedrijven als HR instrument, waarbij bedrijven in 2012 net iets vaker voor werkoverleg kiezen dan voor beoordelingsgesprekken, vergeleken met 20II. Ook andere ontwikkelingen vallen op. Er is ten opzichte van vorig jaar een toename van het percentage bedrijven dat scholings/ontwikkelingsgesprekken, het gebruik van persoonlijke ontwikkelingsplannen, bedrijfsopleidingsplan, leren onder werktijd en bedrijfsopleidingsbudget als HR instrument noemt om de speerpunten van het personeelsbeleid te realiseren. Al deze HR instrumenten hebben gemeen dat ze (sterk) gerelateerd zijn aan scholing. Dit signaleert het belang dat bedrijven hechten aan opleiding en ontwikkeling, ondanks dat in Hoofdstuk 4 is terug te zien dat de gemiddelde bestedingen van metalektrobedrijven aan opleidingen al jaren dalen. In dit verband is ook de stijging in het percentage bedrijven dat op functieroulatie inzet interessant. Dit kan een creatieve oplossing zijn om met minder scholingskosten toch medewerkers te scholen. Door middel van functieroulatie kunnen medewerkers namelijk nieuwe taken leren en kennis opdoen. Door hier meer op in te zetten kunnen bedrijven bewerkstelligen dat hun medewerkers zich ontwikkelen en in nieuwe competenties bekwamen, ondanks de dalende bestedingen aan opleiding en scholing. 
Figuur 7.5

HR Instrumenten t.b.v. het bereiken van toekomstige speerpunten (\% bedrijven), 2011-2012

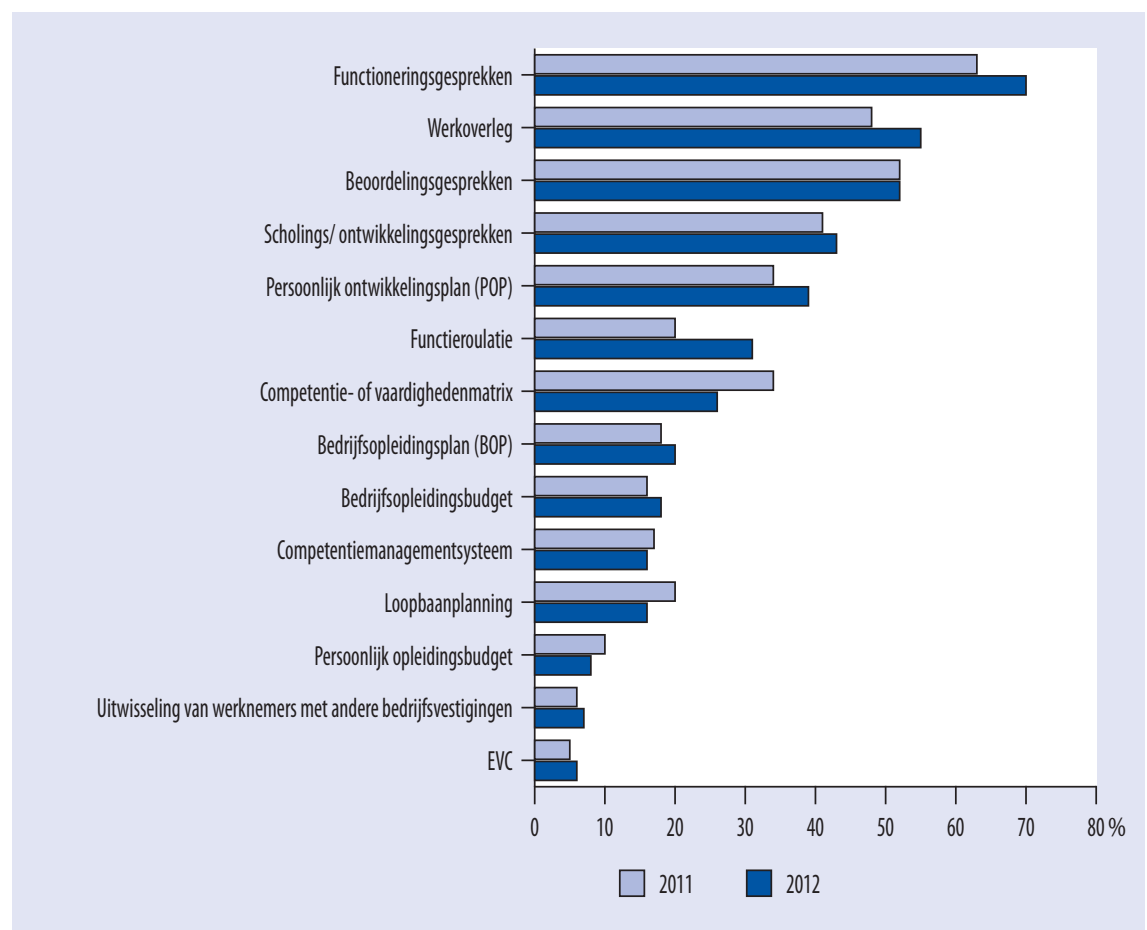

Bron: ROA, Arbeidsmarktmonitor Metalektro, 2011-2012

Precies een derde van de bedrijven verwacht tussen 2013 en 2017 geen knelpunten bij het realiseren van de toekomstige HR speerpunten (Figuur 7.6). Een ruime meerderheid van tweederde van de bedrijven verwacht hierbij dus wel knelpunten. Het probleem dat het vaakst verwacht wordt is dat het personeel moeilijk met veranderingen kan omgaan. Ook verwachten relatief veel bedrijven dat de flexibiliteit van het personeel tekort schiet. Over het kennisniveau van de medewerkers maakt een vijfde van de bedrijven zich zorgen. Opvallend is de grote stijging in het percentage bedrijven dat aangeeft dat er te weinig budget beschikbaar is om de speerpunten van het HR beleid te realiseren. Dit knelpunt speelt met deze stijging ineens weer een grotere rol dan de achterblijvende investeringsbereidheid en veranderingsmotivatie van het personeel, welke stabiel zijn rond de $15 \%$. Dit laat zien dat door het voortduren van de economische crisis de budgettaire problemen belangrijker worden dan de problemen die op de houding van het personeel betrekking hebben. 


\section{Figuur 7.6}

Verwachte knelpunten bij het realiseren van toekomstige speerpunten (\% bedrijven)

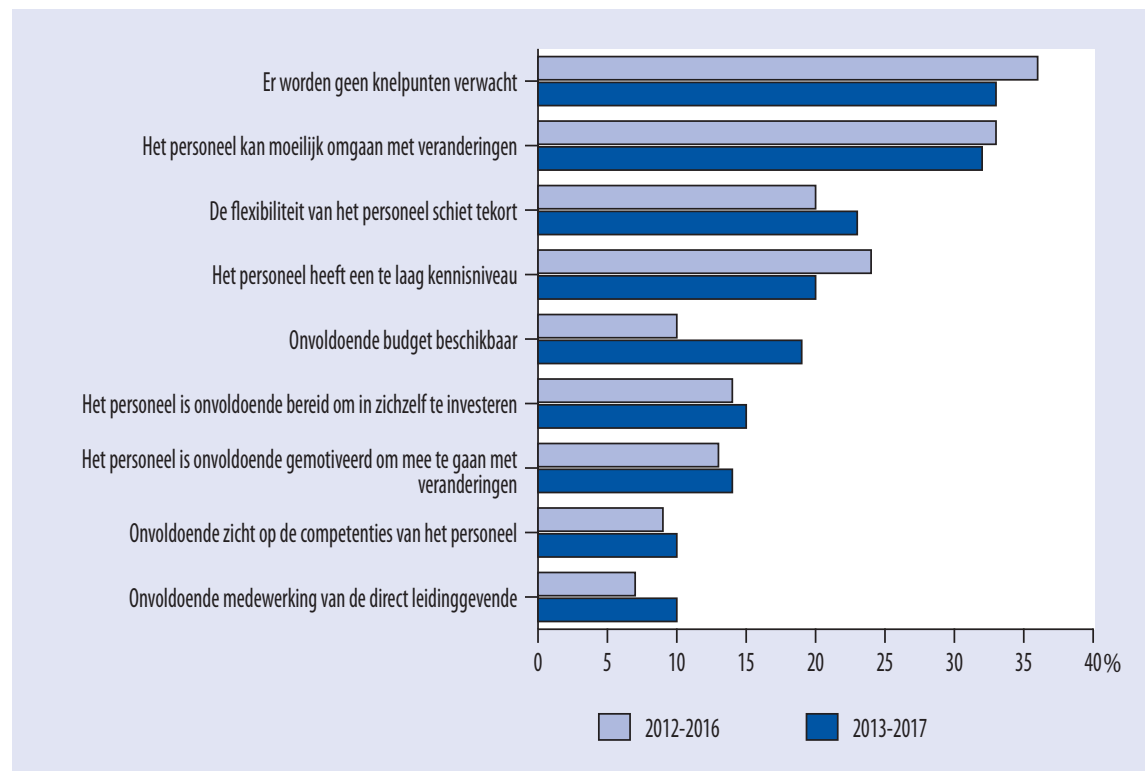

Bron: ROA, Arbeidsmarktmonitor Metalektro, 2011-2012 


\section{Agenda voor de Toekomst}

Het arbeidsmarktbeleid en innovatiegedrag van metalektrobedrijven richt zich in deze economisch woelige tijden voornamelijk op het consolideren van kernactiviteiten met een kern van eigen medewerkers. Van die medewerkers wordt steeds meer een brede en flexibele inzetbaarheid verwacht. Daardoor is in veel metalektrobedrijven de vraag naar breed inzetbare (technische) medewerkers groter dan het aanbod. Dit brengt wel het gevaar met zich mee dat men teveel van medewerkers vraagt. Het feit dat de privé-werk balans en de werkdruk laag scoren als $H R$ speerpunten geeft aan dat veel metalektrobedrijven hier nog weinig aandacht voor hebben. De uitdaging is om op duurzame wijze het aanbod van breed en flexibel inzetbare medewerkers te vergroten. 


\subsection{Inleiding}

De Agenda voor de Toekomst vormt ieder jaar het sluitstuk van de jaarrapportage van de Arbeidsmarktmonitor Metalektro. Dat er ieder jaar weer een Agenda voor de Toekomst wordt opgesteld betekent niet dat de oude agenda niet meer relevant is. Sectoraal arbeidsmarktbeleid en personeelsbeleid op bedrijfsniveau zijn per definitie zaken waarvan men de koers voor een langere termijn moet uitzetten. In de Agenda voor de Toekomst van vorig jaar werd de koers gedetailleerd uitgezet aan de hand van een human capital strategie bestaande uit diverse koop- en maakstrategieën, waaronder: een lange-termijn visie op personeelsbehoefte, wervingsbeleid, loopbaanmanagement, opleidingsbeleid, duurzame inzetbaarheid en sociale innovatie. De lange termijn relevantie van deze koers blijft van kracht, maar dat neemt niet weg dat de ontwikkelingen in 2012 op de korte termijn stuurcorrecties nodig maken om op de lange termijn koers te blijven. De recente ontwikkelingen worden in paragrafen 8.2 en 8.3 geschetst. Paragraaf 8.2 gaat meer in op lange termijn trends, terwijl paragraaf 8.3 in gaat op het HR beleid dat metalektrobedrijven in 2012 gevoerd hebben en in de toekomst verwachten te voeren. In paragraaf 8.4 geven we aan tot welke nieuwe uitdaging de ontwikkelingen uit 2012 hebben geleid. In paragraaf 8.5 besteden we aandacht aan de beleidsterreinen die relevant zijn om de stuurcorrecties te maken en aan de nieuwe uitdaging het hoofd te bieden.

\subsection{Ontwikkelingen die de achtergrond vormen}

In de voorgaande hoofdstukken van dit rapport is onder meer te zien dat de werkgelegenheid in de Metalektro al jaren langzaam daalt (Figuur I.5). Er zijn wel korte periodes waarin de werkgelegenheid tijdelijk toeneemt, zoals in 2007 en 2008 en ook de eerste helft van 2012, maar de dalende trend wordt hierdoor niet gebroken. In de tweede helft van 2012 daalde de werkgelegenheid weer en ook de verwachtingen van bedrijven voor de nabije toekomst wijzen niet op groei (paragraaf 7.I). Daarbij daalde in ieder kwartaal van 2012 de omzet.

Op de middellange tot lange termijn zullen daarnaast nog twee uitdagingen tot wasdom komen: de vergrijzing en de tekorten aan specifiek gekwalificeerde technici. Bedrijven zullen de uitstroom van ouderen op moeten vangen zonder dat het menselijk kapitaal -de kennis en ervaring van deze medewerkers- verloren gaat en zonder dat de continuïteit van de bedrijfsvoering in gevaar komt. Daarnaast zijn er nu voor bepaalde functies al vacatures waarvoor de geschikte kandidaat maar moeilijk tot zeer moeilijk te vinden is. Hoewel de symptomen van deze tekorten door de economische crisis momenteel aan het zicht onttrokken worden, is de fundamentele oorzaak van de tekorten nog niet weggenomen: de discrepantie tussen vraag en aanbod van bepaalde typen technisch opgeleiden. Wanneer precies en in welke hevigheid de effecten van de vergrijzing en tekorten voelbaar zullen worden is moeilijk te voorspellen. Dit hangt ook af van de maatregelen die bedrijven nu al treffen. Herstel van de omzet, de aanko- 
mende vergrijzing en tekorten aan personeel zijn dus drie belangrijke uitdagingen die direct verband houden met de continuïteit van de bedrijfsvoering in veel metalektrobedrijven.

\subsection{Consolidatie op kernactiviteiten en kern van vaste medewerkers}

Vooral de tweede helft van 2012 was een zware periode voor de Metalektro. Toch was er in deze tweede helft van het jaar in verschillende functies nog sprake van werkgelegenheidsgroei (instroom>uitstroom), voornamelijk voor uitvoerende en leidinggevende technische functies en engineering en R\&D personeel (Figuur 2.6). Dit zijn de medewerkers die doorgaans het dichtst bij het primaire proces van het bedrijf staan en die verantwoordelijk zijn voor product- en procesinnovatie. Het lijkt er dus op dat bedrijven ervoor kiezen om enerzijds de personele bezetting rondom de kernactiviteiten te bewaken en deze kernactiviteiten daarnaast te versterken, wellicht met het oog op het op korte termijn verbeteren van het in 2012 zwaar getroffen bedrijfsresultaat. De netto instroom van $\mathrm{R} \& \mathrm{D}$ personeel kan in samenhang worden gezien met Figuur 5.I, waarin te zien is dat het sterk verbeteren van bestaande producten en productiemethoden in 2012 de meest populaire typen innovatie waren, gevolgd door de ontwikkeling van nieuwe producten. Dit blijven volgens de bedrijven de komende jaren ook de voornaamste typen van innovatie. Met de ontwikkeling van nieuwe producten zullen bedrijven op de middellange en lange termijn hun omzet in de steigers willen zetten.

Daarnaast werd de flexibele schil in 2012 verder afgebouwd. Met name de grootste groepen flexibele krachten, flexibel ingehuurde uitvoerende technici en ondersteunende technici werden verkleind (Figuur 2.9). Afbouw van de flexibele schil betekent automatisch dat het werk dat hieruit overblijft onder werknemers met een vast contract wordt verdeeld. Hoofdstuk 3 liet daarbij zien dat het aantal vacatures in 2012 daalde en dat onvervulde vacatures voornamelijk opgevangen werden door zittende medewerkers flexibel in te zetten of overuren te laten draaien. Deze strategieën om met onvervulde vacatures om te gaan en de flexibele schil af te bouwen, wijzen er duidelijk op dat bedrijven teruggrijpen op hun vaste kern van medewerkers. Ook dit is een beweging die te kenschetsen is als consolidatie; terug naar de kern van vaste werknemers en die vaste kern aan het werk houden.

Voor de nabije toekomst verwachten bedrijven eveneens minder uitbestedingen van werkzaamheden binnen Nederland of naar het buitenland (Figuren 5.II en 5.I2). Dit kan ook gezien worden als het afbouwen van een flexibele schil die buiten de kern van het eigen bedrijf bestaat. Ook dit zal waarschijnlijk bepaalde werkzaamheden terug leiden naar de eigen kern van medewerkers.

Tot slot geven metalektrobedrijven aan dat ze de verwachte problemen met vervanging van uittredende ouderen vooral willen opvangen door personeel breed in te 
zetten en door zich te richten op duurzame inzetbaarheid van het personeel. Ook dit zijn strategieën die betrekking hebben op de vaste werknemers (paragraaf 6.3).

\subsection{Op een duurzame manier het aanbod van breed inzetbare technische medewerkers vergroten}

\section{Meer vraag naar breed inzetbare (technische) medewerkers}

Bovenstaande ontwikkelingen wijzen er op dat er in toenemende mate een groot beroep wordt gedaan op de vaste medewerkers, om flexibel en breed inzetbaar te zijn, rondom de eigen kernactiviteiten van het bedrijf. In Figuur 5.7 was dan ook te zien dat metalektrobedrijven in 2012 een sterk toegenomen behoefte hadden aan breed inzetbare uitvoerende technici. Ook de redenen die bedrijven aangeven waarom ze behoefte hebben aan breed inzetbare technici komen overeen met de ontwikkelingen die in paragraaf 8.2 werden beschreven. De meest genoemde redenen zijn (Figuur $5.8):{ }^{23}$

(I) om schommelingen in de bedrijfsdrukte op te vangen (70\%);

(2) vervanging tijdens afwezigheid (53\%);

(3) product en/of procesvernieuwing (4I\%);

(4) aantrekkelijker maken van de functies (39\%);

(5) vergrijzing van het personeelsbestand (28\%);

(6) tekorten aan bepaalde werknemers (24\%).

Er is dus een grote consistentie in de antwoorden van de bedrijven op de vragen in de enquêtes van de arbeidsmarktmonitor. Wat daarnaast nog opvalt als men de diverse ontwikkelingen in samenhang en over de tijd bekijkt, is dat in 2010 en 2OII, toen de Metalektro nog een positieve omzetontwikkeling kende, de flexibele schil een piekomvang bereikte en er een dalende vraag was naar breed inzetbaar technici. Daarentegen werd in 2012 toen de omzet daalde, de flexibele schil afgebouwd en steeg de vraag naar brede inzetbaarheid van technici. Dit laat duidelijk zien dat de vraag naar brede inzetbaarheid van technici mee fluctueert met de conjunctuur.

\section{Te weinig aanbod van breed inzetbare medewerkers}

Hebben bedrijven wel de beschikking over voldoende breed inzetbaar personeel? Gevraagd naar de beschikbaarheid van breed inzetbaar personeel, bleek dat bij een derde van de bedrijven de vraag naar breed inzetbare uitvoerende technici de beschikbaarheid overtreft (Figuur 5.9). Voor een vijfde van de bedrijven geldt bovendien dat hun ondersteunende technici onvoldoende breed inzetbaar zijn. Dit geeft aan dat het

23. Tussen haakjes het percentage metalektrobedrijven dat deze reden noemt, er waren meerdere antwoorden mogelijk. 
juist voor deze twee grootste functiecategorieën in de sector van groot belang is om hun inzetbaarheid te vergroten.

\section{De uitdaging voor de toekomst}

Veel metalektrobedrijven hebben dus een stijgende vraag naar breed en flexibel inzetbare technici, maar het aanbod hiervan blijft bij veel van de metalektrobedrijven achter bij de vraag. Breed inzetbare technici zijn dus schaars. Hierdoor bestaat het gevaar dat er een té groot beroep wordt gedaan op deze schaarse groep breed inzetbare medewerkers. $\mathrm{Nu}$ al geven bedrijven aan dat ze in veel gevallen de gevolgen van onvervulde vacatures (personeelstekorten) opvangen door hun medewerkers overuren te laten draaien, en het opvangen van tekorten was maar een van de vele redenen waarom bedrijven een groeiende behoefte hebben aan breed inzetbare mensen. Het werken van overuren levert op de langere termijn aantoonbare risico's op voor de duurzame inzetbaarheid van mensen (Hoofdstuk 6). Daarbij geven maar weinig bedrijven aan dat het afstemmen van de privé-werk balans en het verminderen van de werkdruk speerpunten zijn van het toekomstige personeelsbeleid. Beide worden door amper vijf procent van de bedrijven genoemd (Figuur 7.4).

De uitdaging voor de Metalektro is om op een duurzame manier het aanbod van breed en flexibel inzetbare technici te vergroten.

\subsection{Relevante beleidsterreinen}

\section{Scholing}

Metalektrobedrijven onderkennen dat de toenemende vraag naar breed inzetbare technici samenhangt met veranderingen in de inhoud van functies. De door bedrijven meest voorziene veranderingen zijn namelijk dat gedragsmatige competenties belangrijker worden, dat technische functies meer allround worden en dat meer verantwoordelijkheden komen te liggen bij technische functies op een lager niveau in de organisatie. Dit onderstreept het belang van de gedragsmatige competenties uit de vorig jaar al aangeduide PROFI-agenda:

- Probleemoplossend vermogen

- Relatie met klanten

- Omgaan met veranderingen

- Flexibiliteit

- Initiatief

Zowel scholing als het verbeteren van het leerklimaat op de werkvloer zijn bij uitstek geschikt om de ontwikkeling van deze competenties, en daarmee de brede inzetbaarheid van medewerkers, te bevorderen. Scholing kan ook voor bredere inzetbaarheid 
zorgen door verdieping of verbreding van vaktechnische kennis en vaardigheden. De bestedingen van metalektrobedrijven aan opleidingen als percentage van de loonsom lopen echter al jaren terug en het jaar 2012 was hierop geen uitzondering (zie Figuur 4.3). Wel was er in 2012 een stijging van het percentage bedrijven dat functieroulatie heeft toegepast (Figuur 4.8). Dit is een goede zaak. Door het uitoefenen van een andere functie leert een medewerker weer nieuwe dingen en wordt men praktisch gezien ook meteen breed ingezet. Dit is dus een vorm van informeel leren ('learning by doing'). Ondanks deze creatieve manier om met gesloten beurs naar wegen te zoeken om medewerkers te laten leren, baren de dalende bestedingen aan opleidingen zorgen in het licht van het belang dat scholing kan hebben om medewerkers breder inzetbaar te maken.

\section{Flankerend gebruik van organisatorische innovaties en HR instrumenten}

Gevraagd naar de organisatorische innovaties die de bedrijven in 2012 doorvoerden blijkt dat het variabel inzetbaar maken van het eigen personeel het meest genoemd werd. Ook bij de vraag welke organisatorische innovatie men de komende vijf jaar nastreeft is dit het meest gegeven antwoord. Dit geeft aan dat metalektrobedrijven bewust inspelen op de groeiende behoefte aan breed inzetbare medewerkers en het tot voornaamste punt van organisatorische innovatie maken. Gevraagd naar het doel van deze organisatorische innovatie, wordt het vaakst aangegeven dat men hiermee de productie flexibeler wil maken en schommelingen in de bedrijfsdrukte beter op wil kunnen vangen. Dit is weer consistent met de eerdere bevindingen uit paragraaf 8.2.

De HR speerpunten van bedrijven laten ook duidelijk zien dat bedrijven optimaal gebruik willen maken van de kern van eigen medewerkers. De twee meest genoemde speerpunten zijn namelijk: (I) de inzetbaarheid van het personeel en (2) het verminderen van het verzuim. Het HR instrument dat de grootste stijging in populariteit kent en dat bedrijven meer verwachten in te zetten dan in het verleden is functieroulatie. Daarnaast is er een stijging in het percentage bedrijven dat gebruik wil gaan maken van persoonlijke ontwikkelplannen, scholingsgesprekken, werkoverleg en functioneringsgesprekken. Dit wijst er op dat ondanks de voortdurende daling in (formele) opleidingsuitgaven, de bedrijven in de Metalektro zich er van bewust zijn dat het grotere beroep dat ze doen op de brede en flexibele inzetbaarheid van hun medewerkers, gepaard moet gaan met flankerende maatregelen. Men lijkt dus boter bij de vis te doen door deze HR instrumenten meer in te willen zetten, waarbij dit allen HR instrumenten zijn die geen 'out of pocket' kosten met zich meebrengen.

Daarentegen neemt het gebruik van enkele andere HR instrumenten, waaronder de erkenning van verworven competenties (EVC) en competentie- en vaardighedenmatrices, de laatste jaren af. Juist in tijden waarin metalektrobedrijven steeds creatiever lijken te worden om hun medewerkers leermogelijkheden te bieden op de werkvloer, verdient dit meer aandacht. Het is voor de employability van de medewerkers name- 
lijk van belang dat nieuw verworven kennis en vaardigheden van tijd tot tijd geformaliseerd worden door middel van een EVC traject.

\section{Werving}

Zoals in Hoofdstuk 3 uitgebreid is toegelicht, is werving en selectie van geschikt personeel de laatste jaren voor veel bedrijven in de Metalektro een moeizame kwestie. De belangrijkste wervingsproblemen die al jaren de boventoon voeren zijn de onjuiste competenties van sollicitanten en een gebrek aan werkervaring. Juist omdat de werving en selectie vaak zo moeizaam verloopt, kunnen metalektrobedrijven hier niet op vertrouwen om op korte of middellange termijn het aanbod van breed inzetbare technici binnen het bedrijf te vergroten. Dit onderstreept het belang van scholing en het flankerend gebruik van organisatorische innovaties en HR instrumenten die het informele leren op de werkvloer bevorderen, om aan de groeiende vraag naar breed inzetbare technici tegemoet te komen. 
